\title{
Escaping the Asylum: When Freedom Is a Crime
}

\author{
GRANT H. MORRIS*
}

\section{TABLE OF CONTENTS}

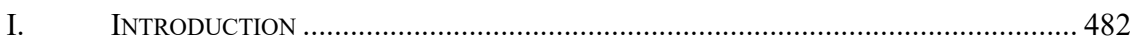

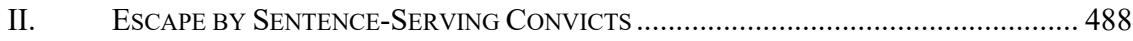

III. ESCAPE BY "SPECIAL” CIVILLY COMMITTED NONCONVICTS........................................ 499

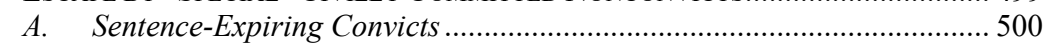

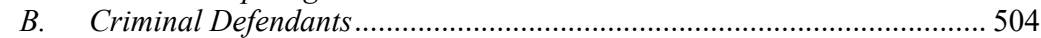

1. Mentally Incompetent Criminal Defendants .................................... 505

2. Permanently Incompetent Criminal Defendants ............................ 510

C. Insanity Acquittees ......................................................................... 517

D. Sexually Violent Predators .................................................................... 531

IV. Conclusion: Protecting the Public Without

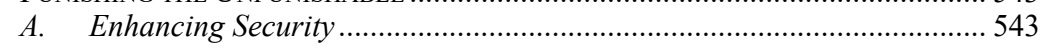

B. Providing Treatment Opportunities ..................................................... 545

C. Clarifying the Authority to Apprehend Escapees .................................... 550

D. Perceiving Patients, Not Prisoners ..................................................... 552

* C Grant H. Morris 2003. Professor of Law, University of San Diego School of Law; Clinical Professor, Department of Psychiatry, School of Medicine, University of California, San Diego; member of the Atascadero State Hospital Advisory Board. I would like to thank Erika Fernbach for her research assistance, Michael Perlin and David Naimark, M.D., for their helpful comments on a draft of this Article, and the University of San Diego for the financial support that it provided to this project. 


\section{INTRODUCTION}

On September 22, 2001, ${ }^{2}$ Ronald Rogers, a sexually violent predator (SVP) involuntarily committed to Atascadero State Hospital, went to a courtyard area within that facility, scaled a wall, jumped to the ground outside the secure fenced area, and escaped. ${ }^{3}$ A San Luis Obispo County Superior Court judge issued a warrant for Rogers's arrest, ${ }^{4}$ charging him $^{5}$ with escape and failure to register as a sex offender. ${ }^{6}$ A federal warrant was also issued charging Rogers with unlawful flight to avoid

1. The Beatles, $I$ Am the Walrus, on The Beatles Magical Mystery Tour AlbuM (EMI Records Ltd. 1967).

2. Rogers's last pre-escape contact with a hospital staff member occurred at 4:30 P.M. on Saturday, September 22, 2001. Staff members conduct patient counts every six hours. In the evening, staff thought they observed Rogers in bed, but the shape was, in fact, pillows. On Sunday, September 23, 2001, staff discovered that Rogers was no longer on the unit. Matt Lazier, Escaped Sex Predator Is Still at Large, TRIBUNE (San Luis Obispo County, Cal.), Sept. 25, 2001, at A1.

3. See Matt Lazier, Sighting Suggests Escapee Could Still Be in the Area, Tribune (San Luis Obispo County, Cal.), Sept. 26, 2001, at A1. Rogers completed his escape by climbing down the roof of the single-story Administration Building, which was not fenced. To prevent future escapes, a ten-foot tall fence with razor wire was subsequently installed on the roof of the Administration Building. E-mail from Barrie Hafler, Public Relations Officer, Atascadero State Hospital, to Grant Morris, Professor of Law, University of San Diego School of Law (Jan. 3, 2003, 12:51:32 PST) (on file with author).

4. E-mail from Barrie Hafler, Public Relations Officer, Atascadero State Hospital, to Grant Morris, Professor of Law, University of San Diego School of Law (Feb. 22, 2002, 09:32 PST) (on file with author). Atascadero State Hospital is located in San Luis Obispo County, approximately twenty miles from the city of San Luis Obispo. A San Luis Obispo newspaper article, published September 26, 2001, reported that the felony arrest warrant was issued for escape and violation of the court order committing Rogers to Atascadero State Hospital. Lazier, supra note 3, at A1. A second article, appearing in the same newspaper eight weeks later, reported that Rogers was charged with escape, failing to register as a sex offender, and violation of the court order committing him to Atascadero State Hospital. Patrick S. Pemberton, Escapee from ASH Faces Extradition, Tribune (San Luis Obispo County, Cal.), Nov. 20, 2001, at B1. A third article, appearing in the same newspaper two months later, reported that the district attorney's office was pursuing two felony charges against Rogers: for escape and for failure to register as a sex offender. Patrick S. Pemberton, Escapee May Slip Through Loophole, TRIBUnE (San Luis Obispo County, Cal.), Jan. 24, 2002, at A1.

5. Male gender pronouns are used throughout this Article. They are used deliberately to reflect the fact that the overwhelming majority of "special" civilly committed mental patients who are the subject of this Article are men. Male gender pronouns are also used when referring to a specific individual, such as Ronald Rogers, who is a man.

6. E-mail from Barrie Hafler, supra note 4. Individuals convicted of various sex offenses are required to register with the local public law enforcement agency authority within five working days of coming into or locating within that city, county, or public university campus. CAL. PenAl CODE $§ 290(a)(1)(A)$, (a)(2) (West Supp. 2003). 
prosecution. ${ }^{7}$ Ten days after he escaped, Rogers was apprehended by Oregon State Troopers, and he was returned to California. ${ }^{8}$ At Rogers's preliminary hearing, the court dismissed the criminal charges against him because escape by an SVP is not a crime in California. ${ }^{9}$ Because Rogers was not "fleeing" to avoid a state prosecution for escape, no federal crime was committed either. ${ }^{10}$

This Article considers the constitutionality and desirability of laws that criminalize escape by civilly committed mentally ill patients. Although escape by sentence-serving convicts is a crime in many states, ${ }^{11}$ escape by "regular" civilly committed mental patients is not. Nevertheless, some states criminalize escape by "special" civilly committed patients, such as individuals acquitted of crime by reason of insanity (insanity acquittees) ${ }^{12}$ and $\mathrm{SVPs}^{13}{ }^{13}$ and other states are

7. E-mail from Barrie Hafler, supra note 4. Pursuant to federal statute, a person who travels in interstate commerce with the intent to avoid prosecution for a crime under the laws of the place from which the person flees commits a federal crime punishable by fine or imprisonment for not more than five years, or both. 18 U.S.C. $\S 1073$ (2000). This statute may be used either to prosecute the person for violation of the federal statute, see United States v. McCord, 695 F.2d 823, 825 (5th Cir. 1983), or to "permit[] federal law enforcement agents to apprehend state fugitives, release them to local authorities in the state of arrest, and allow extradition to the state in which the federal offense was committed," United States v. Love, 425 F. Supp. 1248, 1250 (S.D.N.Y. 1977). In this latter situation, the statute is used "to aid the state in obtaining custody of one of its prisoners" so that the prisoner can be returned to the state to face state charges. McCord, 695 F.2d at 826.

8. See E-mail from Barrie Hafler, supra note 4.

9. Id.

10. See id.

11. See, e.g., Ala. CoDE \&\& 13A-10-31 to -33 (1994); AlaSka STAT. § $\$ 11.56 .300$ to .330 (Michie 2000); ARIz. REV. STAT. ANN. $\S \S 13-2502$ to -2504 (West $2001 \&$ Supp. 2002); CAL. Penal CODE § 4530 (West 2000); Fla. STAT. AnN. § 944.40 (West 2001); Iowa Code AnN. § 719.4 (West Supp. 2003); N.J. Stat. AnN. § 2C:29-5(a) (West 1995); N.Y. Penal LaW $\S \S 205.05-.15$ (McKinney 1999); 18 PA. Cons. Stat. ANN. $\S$ 5121(a) (West 1983); WASH. REV. CODE ANN. § 9A.76.115 (West Supp. 2003); WIS. STAT. ANN. § 946.42(2)-(3) (West Supp. 2002); see also 18 U.S.C. § 751 (2000).

12. See, e.g., CAL. Penal Code $\S \S 1026,1026.4(a)$ (West Supp. 2003); Fla. Stat. ANN. $\S 916.105, .1081$ (West 2001). In some states that have not enacted separate statutes criminalizing escape by insanity acquittees, courts have interpreted the basic escape statute to include within the criminal prohibition escape by insanity acquittees. See, e.g., State v. Flemming, 377 A.2d 448, 450-51 (Me. 1977) (holding that an insanity acquittee's escape from a place of lawful detention, that is, a mental institution, is a crime under the state's escape statute); People v. Walter, 499 N.Y.S.2d 280, 280-81 (App. Div. 1986) (holding that escape by an insanity acquittee from a secure mental health facility is a crime under a statute prohibiting escape from a "detention facility").

13. See, e.g., Fla. Stat. AnN. § 394.927(1) (West 2002); IOWA CodE ANN. $\S \S$ 229A.5B.1, .2 (West Supp. 2002); VA. CoDE ANN. § 37.1-70.18 (Michie Supp. 2002) 
considering enacting laws to do so. For example, in direct response to Ronald Rogers's much publicized escape from Atascadero State Hospital, California Assemblyman Abel Maldonado, whose district includes that hospital, introduced legislation ${ }^{14}$ that would criminalize escape by SVPs ${ }^{15}$ and mentally disordered offenders. ${ }^{16}$ Both groups consist of individuals who were civilly committed to Atascadero State Hospital following completion of their criminal sentences. ${ }^{17}$ The bill appeared to be a logical extension of existing California statutes that currently criminalize escape by insanity acquittees ${ }^{18}$ and mentally disordered sex offenders. ${ }^{19}$ The California District Attorneys Association,

(effective Jan. 1, 2004); WASH. Rev. CodE ANN. § 9A.76.115 (West Supp. 2003).

14. Assemb. B. 1755, 2002 Leg., 2001-02 Reg. Sess. (Cal. 2002). The bill was introduced on January 7, 2002 and amended on February 28, 2002.

15. In 1996 the Sexually Violent Predator Act became law in California. See generally CAL. Welf. \& INST. CODE §§ 6600-6609.3 (West 1998 \& Supp. 2003) (defining SVP and establishing the procedures for involuntary commitment, treatment, and release of SVPs). The patient census for Atascadero State Hospital on July 24, 2002 was 1085 patients. Of that number, 302 were adjudicated as SVPs and an additional 139 were being evaluated and processed as SVPs. SVPs are the most numerous patient subgroup in Atascadero State Hospital. E-mail from Barrie Hafler, Public Relations Officer, Atascadero State Hospital, to Grant Morris, Professor of Law, University of San Diego School of Law (July 29, 2002, 16:38:52 PDT) (on file with author).

16. See generally CAL. PENAL CODE $\S \S 2960-2981$ (West 2000 \& Supp. 2003) (establishing the procedures for involuntary commitment, treatment, and release of severely mentally disordered prisoners whose mental condition, at the time of their parole or termination of their parole, cannot be kept in remission without treatment). Although commonly known as the Mentally Disordered Offenders (MDO) Law, the words "mentally disordered offenders" do not appear in the statutes. The statutes are found in a portion of the California Penal Code entitled: "Disposition of Mentally Disordered Prisoners upon Discharge." On July 24, 2002, there were 264 mentally disordered offenders in the patient population of Atascadero State Hospital plus an additional forty-seven mentally disordered offenders being evaluated and processed for continued treatment and six others being evaluated for possible outpatient treatment. Mentally disordered offenders are the second most numerous patient subgroup in Atascadero State Hospital. E-mail from Barrie Hafler, supra note 15.

17. See generally infra notes 113-17 and accompanying text (mentally disordered offenders); infra notes 288-90 and accompanying text (SVPs).

18. CAL. PenAl CodE $§ 1026.4$ (West Supp. 2003). On July 24, 2002, there were sixty insanity acquittees in the patient population of Atascadero State Hospital. E-mail from Barrie Hafler, supra note 15.

19. CAL. WELF. \& INST. CODE $\S 6330$ (repealed 1981). Although the mentally disordered sex offender statutes were repealed in 1981, the California Legislature declared its intent to construe the repealing legislation not to affect any person committed as a mentally disordered sex offender prior to the repeal of the statutes. Id. $\S$ 6300 (repealed 1981) (Historical and Statutory Notes (quoting Act of Sept. 27, 1981, ch. 928 , \& 3, 1981 Cal. Stat. 3484, 3485)). Under the now-repealed California law, a mentally disordered sex offender was defined as "any person who by reason of mental defect, disease, or disorder, is predisposed to the commission of sexual offenses to such a degree that he is dangerous to the health and safety of others." Id. The term "sexual psychopath" as used in any California statute was declared to refer to and be synonymous with "mentally disordered sex offender." Id. A person convicted of any sex offense could be subjected to mentally disordered sex offender commitment (for an 
California State Sheriffs' Association, the City of Atascadero, and the Office of the Attorney General all registered their support for the bill. ${ }^{20}$ Although the legislature tends to react favorably to politically popular bills, such as this one, which promised a frightened public that dangerous people - violent repeat offenders and child molesters - would be locked up forever, ${ }^{21}$ this bill was not enacted into law. In fact, the bill did not receive a favorable vote from the Public Safety Committee to which it was assigned. ${ }^{22}$ Assemblyman Maldonado asserted that by rejecting his bill, the Public Safety Committee failed to protect the public. ${ }^{23}$ "I'm afraid these guys don't get it up here... I think the public safety committee should be renamed," 24 said Maldonado.

indeterminate term) in lieu of a determinate criminal sentence. Id. $\S \S 6302,6316-$ 6316.2, 6327 (repealed 1981). Although the mentally disordered sex offender statutes were repealed more than twenty years ago, on July 24,2002 , there were seven mentally disordered sex offenders in the patient population of Atascadero State Hospital. E-mail from Barrie Hafler, supra note 15. In April 2002, the California Committee on Public Safety reported that thirty-five mentally disordered sex offenders remained in California's four state mental hospitals. See Assembly Comm. Report on AB 1755, 2001-02 Reg. Sess. (Cal. Apr. 16, 2002), WL Comm. Rep. CA A.B. 1755.

20. Assembly Comm. Report on AB 1755, WL Comm. Rep. CA A.B. 1755. A newspaper reported that the bill received support from the Atascadero City Council, employee union chiefs, and officials from the California Department of Mental Health. Matt Lazier, SVP Bill May Be Revived in 2002, TRIBUne (San Luis Obispo County, Cal.), Jan. 6, 2002, at B1.

21. An SVP is defined as "a person who has been convicted of a sexually violent offense against two or more victims and who has a diagnosed mental disorder that makes the person a danger to the health and safety of others in that it is likely that he or she will engage in sexually violent criminal behavior." CAL. WELF. \& INST. CODE § 6600(a)(1) (West Supp. 2003). Under California's "Three Strikes" law, conviction of the crime of escape would constitute a third strike against a sex offender who had been previously convicted of two sex offenses, resulting in a sentence of twenty-five years to life. CAL. Penal Code § 667(b)-(i) (West 1999); id. § 1170.12 (West Supp. 2003).

In Atkins v. Virginia, 536 U.S. 304 (2002), Justice Stevens, writing for the majority, stated that it is a "well-known fact that anticrime legislation is far more popular than legislation providing protections for persons guilty of violent crime ...."Id. at 315 . Thus, in his opinion, the enactment of legislation in a large number of states prohibiting the execution of mentally retarded persons was "powerful evidence" that mentally retarded offenders are categorically less culpable than ordinary criminals. Id. at 315-16.

22. By a vote of two in favor and three opposed, the bill failed passage in the Assembly Committee on April 16, 2002, and upon reconsideration, by a vote of two in favor and four opposed, failed passage again on April 23, 2002. Documents Associated with $A B 1755$ in the 2001-2002 Session-Votes, at http://www.assembly.ca.gov/acs/acs frameset2text.htm (last visited Feb. 25, 2003) (listing votes of April 16, 2002 and April 23, 2002).

23. Patrick S. Pemberton, State Sex Offender Escape Bill Fizzles, Tribune (San Luis Obispo County, Cal.), Apr. 17, 2002, at B1.

24. Id. 
Fredricka McGee, Counsel to the Assembly Committee on Public Safety, prepared an analysis of Assemblyman Maldonado's bill, and her analysis provided the rationale for the Committee's decision. ${ }^{25}$ In the historical and statutory notes accompanying the SVP law, the California Legislature expressed its intent to commit and treat SVPs for their disorders "and not for any punitive purposes." 26 After all, as the legislature noted, "these individuals have been duly punished for their criminal acts." 27 A statute specifically declares that SVPs "shall be treated, not as criminals, but as sick persons." ${ }^{28}$ The California Supreme Court found that the California SVP law was a nonpenal, civil commitment scheme. ${ }^{29}$ The Committee on Public Safety noted that no other civilly committed patient is subject to a criminal penalty for escape. $^{30}$ When such patients leave without permission, they are declared AWOL, and when located, are returned to the facility from which they escaped. ${ }^{31}$ If SVPs were subjected to criminal prosecution for the crime of escape, they would be treated, not as other civilly committed patients are treated, but rather, as prisoners serving a criminal sentence. ${ }^{32}$ The "civil nature" of the SVP act could be challenged, and the law found unconstitutional for inflicting punishment on SVPs-a

25. See generally Assembly Comm. Report on AB 1755, 2001-02 Reg. Sess. (Cal. Apr. 16, 2002), WL Comm. Rep. CA A.B. 1755. A nearly identical bill, introduced in the Assembly two years earlier (February 2, 2000) by Assemblyman Maldonado, received a nearly identical analysis, and a similarly unfavorable vote (three in favor and five opposed) by the Committee on Public Safety on March 28, 2000. See Documents Associated with AB 1833 in the 1999-2000 Session-Votes, at http://www.assembly.ca. gov/acs/acsframeset2text.htm (last visited Feb. 25, 2003) (listing vote of March 28, 2000).

26. CAL. Welf. \& InST. CODE $§ 6600$ (West 1998 \& Supp. 2003) (Historical and Statutory Notes (quoting 1995 Cal. Stat. 762 § 1; 1995 Cal. Stat. $763 \S 1$ ))

27. Id.

28. CAL. Welf. \& InST. Code $\S 6250$ (West 1998). However, it should be noted that the statute also specifically includes mentally disordered sex offenders as persons who "shall be treated, not as criminals, but as sick persons," $i d$., and yet they are subject to prosecution for the crime of escape, $i d . \S 6330$ (repealed 1981). Additionally, section 6250 declares that "[n]othing in this part [dealing with persons subject to judicial commitment to mental treatment facilities] shall be held to change or interfere with the provisions of the Penal Code and other laws relating to mentally disordered persons charged with crime or to the criminally insane." Id. § 6250.

29. Hubbart v. Superior Court, 969 P.2d 584, 606 (Cal. 1999). The California Supreme Court also noted that, consistent with the legislature's intent to treat sexually violent predators as sick people and not as criminals, the SVP commitment law was not placed in the Penal Code, but rather was placed in the Welfare and Institutions Code, "surrounded on each side by other schemes concerned with the care and treatment of various mentally ill and disabled groups." Id. The Assembly Committee on Public Safety also mentioned this statutory placement in its analysis of the Maldonado bill. Assembly Comm. Report on AB 1755, 2001-02 Reg. Sess. (Cal. Apr. 16, 2002), WL Comm. Rep. CA A.B. 1755.

30. Id.

31. Id.

32. See id. 
violation of the ex post facto prohibition ${ }^{33}$ - when such punishment could not be imposed on other patients subjected to the state's civil commitment laws - a violation of the equal protection requirement. ${ }^{34}$

Does the criminalization of escape by SVPs threaten the constitutionality of the SVP commitment law, as the Committee on Public Safety asserts? And if so, does criminalization of escape by other specially civilly committed patients threaten the constitutionality of laws authorizing their commitment? This Article analyzes those issues. Part II explains why escape by sentence-serving convicts is typically criminalized, regardless of whether they escape from prison or from another place of confinement or custody. Part III examines the civil commitment laws for specially categorized patients, such as mentally ill convicts whose term of imprisonment is about to expire, defendants in criminal cases who have been found mentally incompetent to stand trial, insanity acquittees, and SVPs. Pivotal Supreme Court decisions involving these specially categorized patients are analyzed to assess whether criminalization of escape by these patients is constitutional. Of particular interest is the equal protection argument: If regular, civilly committed mental patients are not prosecuted and punished for escape, can specially civilly committed patients be prosecuted and punished? Part IV considers alternatives to the criminalization of escape that would assure the public's safety while avoiding constitutional challenges. Criminalization

33. Article I, Section 9, Clause 3 of the United States Constitution, made applicable to the states through the Fourteenth Amendment, provides that no "ex post facto Law shall be passed." U.S. CONST. art. I, § 9, cl. 3. Conceivably, such punishment could violate the double jeopardy clause as well. The Fifth Amendment, made applicable to the states through the Fourteenth Amendment, provides that no person shall "be subject for the same offence to be twice put in jeopardy of life or limb." U.S. Const. amend. V. In Hubbart, the California Supreme Court held that even if the legislature's expressed intent is to create a civil commitment law, "a party raising an ex post facto claim is not precluded from demonstrating that the statute is "so punitive either in purpose or effect as to negate' the stated intent." 969 P.2d at 606 (quoting Kansas v. Hendricks, 521 U.S. 346, 361 (1997) (quoting United States v. Ward, 448 U.S. 242, 248-49 (1980))). However, in Seling v. Young, 531 U.S. 250 (2001), the United States Supreme Court held that if a statute, such as an SVP commitment law, is found to be civil in nature, it cannot be deemed to be punitive in violation of the double jeopardy and ex post facto clauses simply because it is applied in a punitive fashion to a single individual. $I d$. at 263. The offended individual must look to a state law cause of action for relief, see id. at 265 , or possibly challenge the constitutionality of the commitment scheme claiming a due process or other violation. The Court expressly did not consider these other potential constitutional challenges in this case. See id. at 266.

34. The Fourteenth Amendment provides that no state shall "deny to any person within its jurisdiction the equal protection of the laws.” U.S. CONST. amend. XIV, § 1. 
of escape by mental patients may be an unnecessary, and unwise, policy judgment if the risk of escape can be minimized through enhanced security measures to prevent escape, treatment opportunities that offer patients the prospect of release, and clarification of authority to apprehend and return patients if an escape does occur. Nevertheless, this Article concludes by questioning whether public pressure to confine and, if possible, punish specially civilly committed patients will preclude use of these rational alternatives to criminalization of patient escape.

\section{ESCAPE BY SENTENCE-SERVING CONVICTS}

"Escape" is defined as "a voluntary departure from custody with an intent to avoid confinement." 35 By criminalizing escape, the legislature seeks to deter such conduct by incarcerated individuals in order to assure "the integrity of custodial authority and confinement facilities." 36 Additionally, escape endangers society. To facilitate an escape, the prisoner may kidnap a hostage, kill a guard, steal a car, or rob a store. ${ }^{37}$ The unpunished escapee may be more likely to return to a life of crime.

Although the language of escape statutes varies widely, most statutes expressly prohibit escape from: (1) the custody of a specified law enforcement or correctional officer or such officers in general, ${ }^{38}$ (2) custody or official detention, ${ }^{39}$ or (3) specified detention or correctional facilities or such facilities in general. ${ }^{40}$ For example, to be found guilty

35. United States v. Nix, 501 F.2d 516, 519 (7th Cir. 1974). Even the dissenting judge in this case specifically accepted the majority's definition. Id. at 520 (Pell, J., dissenting).

36. People v. Davis, 212 Cal. Rptr. 673, 675 (Ct. App. 1985).

37. Nix, 501 F.2d at 519.

38. See, e.g., 18 U.S.C. $§ 751$ (2000) (escape from the custody of the Attorney General); CAL. PENAL CODE $\S 4530$ (West 2000) (escape from the custody of prison officials, officers, or employees); IOWA CODE ANN. § 719.4 (West Supp. 2003) (escape from the custody of any public officer, public employee, or any other person to whom the person has been entrusted).

39. See, e.g., Ala. CODE $\S \S 13 \mathrm{~A}-10-31,-33$ (1994) (escape from custody); Alaska STAT. $\S \S 11.56 .300$ to .330 (Michie 2000) (escape from official detention); ARIZ. REV. STAT. ANN. $\S \S 13-2502$ to -2504 (West $2001 \&$ Supp. 2002) (escape from custody); N.J. STAT. AnN. § 2C:29-5(a) (West 1995) (escape from official detention); N.Y. PENAL LAW $\S \S 205.05-.15$ (McKinney 1998) (escape from custody); 18 PA. Cons. STAT. ANN. § 5121(a) (West 1983) (escape from official detention); WASH. REV. CODE ANN. §§ 9A.76.110-.130 (West 2000 \& Supp. 2003); Wis. STAT. AnN. § 946.42(2), (3) (West Supp. 2002) (escape from custody).

40. See, e.g., AlA. CODE § 13A-10-32 (1994) (escape from a penal facility); AlASKA STAT. $\S \S 11.56 .310$ to .320 (Michie 2002) (escape from a correctional facility); ARIZ. REv. StAT. ANN $\S \S 13-2503$ to -2504 (West 2001 \& Supp. 2002) (escape from a juvenile secure care facility, a juvenile detention facility, or an adult correctional facility); CAL. PENAL CODE $\S 4530$ (West 2000) (escape from a state prison, prison road camp, prison forestry camp, other prison camp, or prison farm); FLA. STAT. ANN. $\S$ 944.40 (West 2001) (escape from a prison, jail, private correctional facility, road camp, or other penal institution); IOWA CODE ANN. $§ 719.4$ (West Supp. 2003) (escape from a 
of the federal felony of escape, the defendant must have: (1) escaped or attempted to escape; (2) from the custody of the Attorney General, his appointed agent, or from a place where the defendant was confined at the direction of the Attorney General; (3) where the custody was by virtue of either an arrest on a felony charge or a conviction of any offense. $^{41}$ Because a person may be lawfully detained pending trial, conviction of the criminal charge for which the person was held at the time of escape is not required to convict him of the crime of escape. ${ }^{42}$

Generally, courts have broadly construed statutory language requiring that for the crime to be committed, the prisoner must escape from the custody of a law enforcement or correctional officer or that the prisoner must escape from a detention or correctional facility. ${ }^{43}$ Escape can occur even when the statutorily specified officer does not have actual custody over the prisoner at the time of escape or when the prisoner escapes, not from the penal institution to which he was initially detained, but rather from a nonpenal institution, such as a hospital, to which the prisoner was transferred for treatment. ${ }^{44}$ For example, the Court of Appeals for the

detention facility, community-based correctional facility, or institution to which the person has been committed); N.Y. PENAL LAW $\S \S 205.10-15$ (McKinney 1998) (escape from a detention facility); WASH. REV. CODE ANN. $\S \S 9$ A.76.110-.120 (West Supp. 2003) (escape from a detention facility).

41. 18 U.S.C. § 751 (2000); see United States v. Vanover, 888 F.2d 1117, 1121 (6th Cir. 1989); United States v. Edrington, 726 F.2d 1029, 1031 (5th Cir.1984).

42. See, e.g., United States v. Roy, 830 F.2d 628, 638 (7th Cir. 1987) (holding that the defendant's acquittal on a bank robbery charge for which he was being detained at the time of his escape was not a defense to the charge of escape); Godwin v. United States, 185 F.2d 411, 413 (8th Cir. 1950) (holding that the dismissal of the indictment charging the defendant with the crime of motor vehicle theft for which he was being detained at the time of his escape was not a defense to the charge of escape).

43. See generally Thomas Trenkner, Annotation, Escape from Public Employee or Institution Other than Correctional or Law Enforcement Employee or Institution as Criminal Offense, 69 A.L.R.3d 625 (1976).

44. Many, but not all, of the cases involve prisoners who were transferred to medical facilities for treatment of some physical condition. See, e.g., Hornsby v. State, 284 S.E.2d 630, 631 (Ga. Ct. App. 1981) (holding that the medical center to which the prisoner was transferred for back pains was a "place of lawful confinement" within the meaning of the escape statute); Best v. Warden, 201 A.2d 490, 491 (Md. 1964) (holding that the hospital to which the prisoner was transferred for medical treatment was "a place of confinement" within the meaning of the escape statute and that the guard did not abandon custody by leaving the prisoner alone to enable the guard to arrange for transportation back to the penitentiary); People v. Smith, 280 N.W.2d 862, 866-67 (Mich. Ct. App. 1979) (holding that the hospital to which the prisoner was transferred for medical treatment was included within the escape statute definition of a prison which includes "the grounds ... under control of ... persons authorized by the department [of corrections] to have prison inmates under their care, custody or supervision ... outside 
District of Columbia Circuit held that a convict, transferred from the District of Columbia Jail to St. Elizabeths Hospital, the District's public mental hospital, was in the custody of the Attorney General even though the Attorney General and the Department of Justice had no control over St. Elizabeths. ${ }^{45}$ Because a statute authorizes the Attorney General to assign prisoners to institutions "whether maintained by ... the federal government, or otherwise," 46 the concept of "custody" was construed to mean legal as well as actual physical custody. ${ }^{47}$ Similarly, the Court of Appeals for the Second Circuit dismissed as "quite without merit" the claim of a prisoner that the Public Health Service guards from whom he escaped while attending his mother's funeral were not representatives of the Attorney General. ${ }^{48}$

These decisions are not limited to federal courts applying a constructive custody concept to the authority of the Attorney General. ${ }^{49}$ The Ohio Court of Appeals, for example, rejected a prisoner's claim that the escape statute did not apply to him because: (1) he had escaped from a state hospital under the jurisdiction of the Department of Mental Hygiene and not the Department of Corrections; (2) that facility was a hospital and not a penitentiary, workhouse, or jail; and (3) he was confined at that facility as a patient and not as a prisoner. ${ }^{50}$ Because the statute specifically prohibited escape from any confinement or restraint imposed as a result of a criminal proceeding, the court held that a convict who escapes from a state hospital violates the statute. ${ }^{51}$

The Supreme Judicial Court of Massachusetts upheld the escape convictions of two prisoners who were transferred from the Massachusetts Correctional Institution at Framingham to the Westboro State Hospital and

an institution ... for the purpose of . . . medical care"). For cases discussing escape from mental hospitals, see infra notes 45-47 and accompanying text, infra notes 50-56 and accompanying text.

45. Frazier v. United States, 339 F.2d 745, 746-47 (D.C. Cir. 1964).

46. D.C. CODE ANN. § 24-201.26 (West, WESTLAW through Dec. 1, 2002) (formerly cited as D.C. CODE ANN. § 24-425).

47. Frazier, 339 F.2d at 746-47. Transfer of physical custody of a mentally ill prisoner to a mental hospital was held to be "neither inconsistent with, nor exclusive of, the legal custody of the Attorney General." Id. at 747.

48. United States v. Piscitello, 231 F.2d 443, 444 (2d Cir. 1956). At the time of the prisoner's escape, the guards were returning the prisoner from New York City to the United States Public Health Service Hospital at Lexington, Kentucky. Id.

49. See, e.g., People v. Smith, 16 Cal. Rptr. 111, 112 (Ct. App. 1961) (holding that an inmate of Folsom Prison, assigned to a prison forestry camp, who left the work area without permission was under the constructive custody of a Department of Corrections officer and thus escaped from the custody of a prison officer in violation of the escape statute).

50. State v. Stapleton, 325 N.E.2d 243, 245 (Ohio Ct. App. 1974). With little discussion, the court rejected the claim as "without merit." Id. at 246.

51. Id. at $245-46$. 
who left that hospital without permission. ${ }^{52}$ In construing the state's escape statute, the court "decline[d] to follow a strictly literal approach." Although that statute did not contain any explicit provision criminalizing escape from a state hospital, the court construed the statute to punish prisoners, whether they escape from a prison or a mental hospital. ${ }^{54}$ The court relied upon another statute that provides that a prisoner placed in a hospital or medical facility shall, during his absence from prison, be considered as in the custody of the officer having charge of the prison, and the time of confinement in the hospital shall be considered as a part of the term of the sentence. ${ }^{55}$ It would seem illogical, said the court, for the legislature to credit the prisoner's sentence for time spent in a hospital, but not to consider the prisoner in custody for the purpose of being punished if he escaped from that hospital. ${ }^{56}$

However, not all judges and all courts agree that a sentence-serving prisoner's escape from a hospital, especially a mental hospital, constitutes the crime of escape. For example, in the Massachusetts case discussed above, a dissenting justice admonished the majority for deviating from the principle that criminal laws should be strictly construed and not extended by mere implication. ${ }^{57}$ In his opinion, the "clear and only purpose" of the statute that considers prisoners placed in a hospital or medical facility to be in the custody of the officer having charge of the prison is to assure that the prisoner will receive credit for time spent in the hospital toward completion of the prisoner's sentence. ${ }^{58}$ To use that statute to criminalize a prisoner's escape from a mental hospital, "unreasonably expands the meaning of an escape statute which on its face appears to specifically delineate the circumstances in which it will render an escape criminal." 59 Using similar reasoning, a unanimous Missouri Supreme Court ruled that the statutory grant of credit for time spent by a prisoner in a mental hospital did not satisfy the escape crime requirement that the prisoner escape from the "custody of any officer or employee of the state department of corrections."

\footnotetext{
52. Commonwealth v. Reed, 306 N.E.2d 816, 817 (Mass. 1974).

53. Id. at 818 .

54. Id.

55. Id. (citing Mass. Gen. Laws AnN. ch. 127, § 119).

56. Id.

57. Id. at 819 (Hennessey, J., dissenting).

58. Id.

59. Id.

60. State v. Burris, 346 S.W.2d 61, 65 (Mo. 1961).
} 
In the District of Columbia Circuit case discussed above, a dissenting judge found that the transfer of the prisoner to St. Elizabeths Hospital effected a change in his physical custody. Because St. Elizabeths Hospital was within the Department of Health, Education and Welfare and was "administered by the Secretary of that Department through a Superintendent responsible to him," $"$ the prisoner did not escape from the custody of the Attorney General, as the indictment against him charged. ${ }^{62}$ Although the Attorney General has a residual right of custody when the prisoner is released from St. Elizabeths, the Attorney General's custody is superseded while the prisoner is in that facility. ${ }^{63}$ The judge expressed his belief that Congress had chosen not to criminalize escape by those confined in St. Elizabeths because those who escape from that facility are mentally ill. ${ }^{64}$ That thought is worthy of further consideration.

If escape by a mental patient from a hospital is not a crime, and if a mentally ill prisoner transferred from prison to a hospital is a patient in that hospital, is there any justification for criminalizing his escape? After all, the prisoner was not transferred for further punishment, but rather for treatment of a mental disorder that could not be treated adequately within the prison environment. ${ }^{65}$ In essence, a prisoner placed in a mental hospital for treatment is not a fit subject for punishment. In so asserting, I do not claim that the prisoner is criminally blameless and could successfully use an insanity defense to avoid further punishment for the crime of escape. Rather, the transfer to the mental hospital interrupts the punishment that the prisoner was receiving for the crime that led to his initial incarceration in prison. Punishment is interrupted regardless of whether the state chooses to credit the time spent in the mental hospital toward the prisoner's sentence. Until the prisoner's mental condition has improved to an extent that he can be returned to

61. Frazier v. United States, 339 F.2d 745, 748 (D.C. Cir. 1964) (Fahy, J., dissenting).

62. Id. Judge Fahy noted that the defendant was indicted solely under that portion of the statute that prohibits escape from the custody of the Attorney General and not that portion of the statute that prohibits escape from an institution in which he had been confined at the direction of the Attorney General. Id.

63. Id. at 749 .

64. Id.

65. The question of when a prisoner's mental disorder is sufficiently serious that transfer from prison to a mental hospital is warranted is beyond the scope of this Article. Surely, many mentally disordered prisoners would benefit from treatment in a mental hospital and many would voluntarily accept transfer to a hospital. See infra notes 76-82 and accompanying text (discussing Vitek v. Jones, 445 U.S. 480 (1980), in which the Supreme Court acknowledged that an involuntary transfer to a mental hospital implicates the prisoner's liberty interest but authorized fewer due process procedural protections to prisoners than to nonprisoners in the decision to involuntarily hospitalize). 
prison to resume punishment, his status as a sentence-serving convict should be suspended, and the prisoner should be treated as any other mental patient. If society does not deem it necessary to criminalize a hospital escape by a civilly committed patient diagnosed with paranoid schizophrenia or other mental disorder, it should not criminalize escape by a convict patient diagnosed with paranoid schizophrenia or other mental disorder. The hospital can adequately protect itself against escape - either by "regular" mental patients or by "convict" mental patients - by imposing security measures appropriate to the patients in that facility. ${ }^{66}$ Those measures depend upon the pathology and severity of each patient's illness, not upon a "convict" label that preceded that illness. ${ }^{67}$

Research discloses that courts have rarely, if ever, seriously considered this argument. ${ }^{68}$ Although I am not confident that, if considered, it would succeed, nevertheless, it is surely worthy of consideration. In virtually all cases involving sentence-serving prisoners escaping mental hospitals, the courts have simply construed the statutory language either to include or to exclude the conduct from it. Courts have not considered whether convict mental patients can be punished for escape from a mental hospital when other mental patients - arguably similarly situated mental patients - cannot.

In one case that briefly considered a prisoner's equal protection argument, the Minnesota Supreme Court affirmed the escape conviction of a sentence-serving felon who had been committed to and escaped from a state mental hospital. ${ }^{69}$ Although the hospital was within the jurisdiction of the Department of Public Welfare, the court ruled that the

66. Obviously, security measures are necessary to protect against inappropriate and dangerous behavior by patients, as well as to protect against escape. Security measures are imposed when patients lack the ability to comprehend and respect the rights of other patients, hospital staff, and the community, should they escape. See Grant H. Morris, The Confusion of Confinement Syndrome: An Analysis of the Confinement of Mentally Ill Criminals and Ex-Criminals by the Department of Correction of the State of New York, 17 BufF. L. ReV. 651, 662 (1968).

67. See id. at 662, 678-79; see also Grant H. Morris, "Criminality" and the Right to Treatment, 36 U. CHI. L. REV. 784, 786, 796-98 (1969) (proposing that mentally ill prisoners be given treatment opportunities equal to those of mentally ill nonprisoners and that security measures be imposed only when appropriate to the patient's condition, not his status as a prisoner).

68. For example, in State v. Knox, 250 N.W.2d 147 (Minn. 1976), the court, in a one-sentence analysis, addressed and rejected the prisoner's equal protection argument. Id. at 154; see infra notes 69-75 and accompanying text.

69. Knox, 250 N.W.2d at 153-54, 157. 
prisoner, despite his physical transfer to the hospital, was within the concurrent custody of the Commissioner of Corrections and the Commissioner of Public Welfare. ${ }^{70}$ Thus, the prisoner's conduct met the statutory requirement that he escape while held "in lawful custody on a charge or conviction of a crime." 71 Although the court acknowledged that the prisoner was civilly committed to the mental hospital ${ }^{72}$ and that other civilly committed patients were not subject to prosecution for escape ${ }^{73}$ the court summarily rejected the prisoner's equal protection argument in a one-sentence analysis: "The obvious, and unquestionably legitimate, legislative purpose behind applying the criminal sanctions of [the escape statute] to [mentally ill convicts civilly committed to a state hospital] is to keep those persons in custody until discharged by due course of law by deterring and punishing escapes." $" 74$

A dissenting justice challenged the majority's logic. In asserting that the escape statute should be applied equally to all civilly committed patients - including prisoner patients - or to none, he asked:

\footnotetext{
If the purpose of the statute is to discourage attempted escape from a mental institution on the theory that the public is in danger from an escapee, why should the statute not apply equally to either patient, that is, one committed from a prison or one committed directly under a civil commitment order? Moreover, if the one under a civil commitment order who attempts to escape is not guilty of a crime on the theory that he is a patient in a mental institution and therefore should be deemed to not have the capacity to commit the offense, how can the patient there under commitment from a prison be any more responsible for his actions? ${ }^{75}$
}

In some related contexts, the United States Supreme Court has suggested that states may distinguish between mentally ill prisoners and mentally ill nonprisoners. In Vitek $v$. Jones,${ }^{76}$ the Court acknowledged that "the involuntary transfer of [a sentence-serving] prisoner to a mental hospital implicates a liberty interest that is protected by the Due Process Clause" 77 and that "involuntary commitment to a mental hospital is not within the range of conditions of confinement to which a prison sentence subjects an individual." ${ }^{178}$ Nevertheless, even though both the convicted felon as well as the ordinary citizen are entitled to due process protections in the commitment process, ${ }^{79}$ the Court distinguished

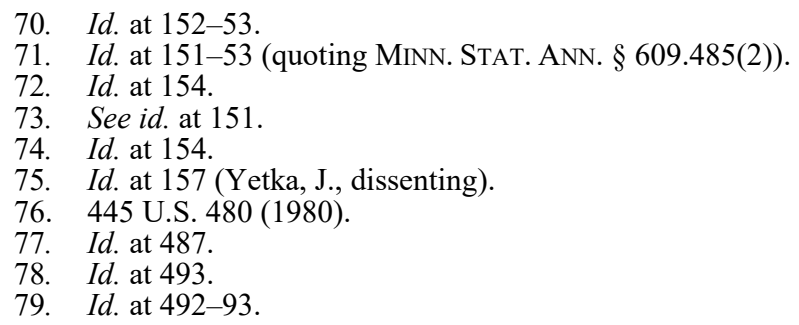


between the two groups as to what procedures are "appropriate in the circumstances." ${ }^{\circ 0}$ For example, the state's interest in avoiding disruption in the prison setting could constitute good cause for limiting the prisoner's right to call witnesses, or to confront and cross-examine witnesses, in the transfer hearing. ${ }^{81}$ The independent decisionmaker conducting that hearing could be a hospital or prison administrator. ${ }^{82}$ Although the Supreme Court has yet to decide what procedures are constitutionally required for involuntary civil commitment of nonconvicts, ${ }^{83}$ obviously, the state cannot claim disruption in the prison setting as a justification for limiting those protections. Just as obviously, a prison administrator will not suffice as the independent decisionmaker when the prospective patient is not a prisoner at the time of the commitment hearing.

Although the state's interest in avoiding prison disruption may distinguish the prison-to-hospital transfer decision for convicts from the freedom-to-hospital commitment decision for nonconvicts, that distinction seems irrelevant to the status of those patients once confined in a mental hospital. If two such patients escape, should one be subject to criminal prosecution because he was transferred into the hospital from a prison,

80. Id. at 493 .

81. See id. at 496.

82. See id. Although a bare majority of the Court held "that qualified and independent assistance must be provided to an inmate who is threatened with involuntary transfer to a state mental hospital," $i d$. at 497 (Powell, J., concurring), only four Justices would require the state to furnish a licensed attorney to the prisoner. See id. at Part IV-B (White, J., joined by JJ. Brennan, Marshall, and Stevens). Justice Powell's concurring opinion that due process can be satisfied by an independent advisor who is not an attorney became the Court's holding on this point. See id. at 497 (Powell, J., concurring).

83. However, the Supreme Court has held that the Constitution does not permit a state to involuntarily commit a nondangerous mentally ill person who can survive safely in freedom either alone or with the help of others. O'Connor v. Donaldson, 422 U.S. 563, 575-76 (1975). Chief Justice Burger, in a concurring opinion, wrote:

There can be no doubt that involuntary commitment to a mental hospital, like involuntary confinement of an individual for any reason, is a deprivation of liberty which the State cannot accomplish without due process of law. Commitment must be justified on the basis of a legitimate state interest, and the reasons for committing a particular individual must be established in an appropriate proceeding. Equally important, confinement must cease when those reasons no longer exist.

Id. at 580 (Burger, C.J., concurring) (citations omitted); see also Addington v. Texas, 441 U.S. 418, 432-33 (1979) (holding that in a civil commitment proceeding, the state is required to prove, by clear and convincing evidence, that the person is both mentally ill and dangerous). 
while the other, who may pose an equal or even greater danger to society, not be subject to prosecution because he was committed to the hospital as too dangerous to live in society? Vitek provides no answer.

In Washington v. Harper, ${ }^{84}$ the Supreme Court considered whether antipsychotic drugs may be administered involuntarily to a mentally ill prisoner. The Court held: "[G]iven the requirements of the prison environment, the Due Process Clause permits the State to treat a prison inmate who has a serious mental illness with antipsychotic drugs against his will, if the inmate is dangerous to himself or others and the treatment is in the inmate's medical interest." 85 Further, the Court ruled that the prisoner was not entitled to a judicial hearing to determine whether he was competent to refuse medication ${ }^{86}$ and upheld administrative hearing procedures in which a hearing committee, composed of a psychiatrist, psychologist, and the associate superintendent of the facility, ${ }^{87}$ reviews the medical treatment decision. ${ }^{88}$ To distinguish prisoners from nonprisoners, the Court in Vitek relied upon the state's legitimate interest in avoiding prison disruption. ${ }^{89}$ To distinguish prisoners from nonprisoners, the Court in Harper relied upon the state's legitimate interest in reducing danger posed by prisoners in the prison environment. ${ }^{90}$ A prison

84. 494 U.S. $210(1990)$

85. Id. at 227 .

86. See id. at 222, 226, 228.

87. Id. at 215. Harper was confined in the Special Offender Center, a Department of Corrections correctional institute established "to diagnose and treat convicted felons with serious mental disorders." Id. at 214.

88. Id. at 232-33. The committee reviews the medical decision that the prisoner has a mental disorder that is likely to cause harm if not treated and that treatment is in the prisoner's medical interests given the legitimate need of the prisoner's institutional confinement. See id. at 222.

89. Vitek v. Jones, 445 U.S. 480, 496 (1980); see also supra notes 76-82 and accompanying text.

90. Harper, 494 U.S. at 225. Less than a year after its Harper decision, however, the Court hinted that its Harper precedent might be applicable to a treatment refusal situation that did not involve danger posed by a prisoner to himself or others. In Perry $v$. Louisiana, 498 U.S. 38 (1990) (per curiam), the Court vacated a Louisiana trial court decision that had ordered a death row inmate to be treated involuntarily with psychotropic medication to restore him to competency to be executed. See State v. Perry, 610 So. 2d 746, 747 (La. 1992). The Supreme Court ordered reconsideration in light of Harper. Perry v. Louisiana, 498 U.S. at 38. Was the Court suggesting that mentally disordered prisoners cannot be treated involuntarily if they are not dangerous? Was the Court suggesting that dangerousness is not the only justification for treatment of mentally disordered prisoners? Was the Court suggesting that proof of dangerousness may justify involuntary treatment of mentally disordered nonprisoners? On remand, the trial court reinstated its order, but the Louisiana Supreme Court reversed. State v. Perry, 610 So. $2 \mathrm{~d}$ at 747, 771. The Louisiana Supreme Court distinguished Harper, holding that the involuntary administration of psychotropic medication for the purpose of restoring competence for execution "does not constitute medical treatment but forms part of the capital punishment sought to be executed by the state." Id. at 753. The court found violations of both the state and federal constitutions. Id. at 755 . 
regulation that is reasonably related to legitimate penological interests will be upheld as valid even if it infringes on prisoners' constitutional rights. ${ }^{91}$ Because prisoners have "a demonstrated proclivity for antisocial criminal, and often violent, conduct," 92 the state's interest in combating the danger posed by prisoners - both to themselves and to others-is greater in the prison environment than elsewhere. ${ }^{93}$

In Harper, the Court did not specifically address the prisoner's equal protection and free speech claims. ${ }^{94}$ Nevertheless, if due process can be satisfied by a prison regulation that is reasonably related to the state's legitimate penological interest in prison safety and security even when it infringes on a prisoner's fundamental constitutional rights, it is unlikely that equal protection and free speech claims, even if independently and fully considered by the Court, would succeed.

Civilly committed patients generally have a right to refuse treatment with psychotropic ${ }^{95}$ medication unless they lack the capacity to make

91. Harper, 494 U.S. at 223 (citing Turner v. Safley, 482 U.S. 78, 89 (1987)). The validity of a prison regulation will be measured by the "reasonable relationship" standard even when the infringed constitutional right is fundamental and a more rigorous standard of review would have been required in nonprison settings. Id. (citing O'Lone v. Estate of Shabazz, 482 U.S. 342, 349 (1987)).

92. Id. at 225 (quoting Hudson v. Palmer, 468 U.S. 517, 526 (1984)).

93. Id.

94. Harper sued in state court, asserting that the state's failure to provide him with a judicial hearing on his competence to refuse medication before administering antipsychotic medication over his objection violated the Due Process, Equal Protection, and Free Speech Clauses of both the Federal Constitution and state constitutions, as well as state tort law which requires informed consent to treatment. See id. at 217. The trial court, the Washington Supreme Court, and the United States Supreme Court addressed only the due process issue. See id. at 217-18 (discussing the trial court decision), 218 $\mathrm{n} .5$ (discussing the Washington Supreme Court decision and citing Harper v. State, 759 P.2d 358,366 (1988)), 219-36 (discussing the substantive and procedural due process issues).

95. In legislation, court decisions, and legal scholarship, the words "psychotropic," "antipsychotic," and "neuroleptic" are often used indiscriminately to refer to medication prescribed to treat people with major mental disorders. However, the words are not synonymous. "Psychotropic" is derived from two root words, "psycho-" meaning the mind or mental processes, and "-tropic" meaning changing or directing. Thus, psychotropic medications include all chemical agents that act on and affect the mind. ROBERT J. WALDINGER, FundAMENTALS OF PSYCHIATRY 396 (1986). Antipsychotic medications, also known as neuroleptic medications or major tranquilizers, are one type of psychotropic medication and are used to treat thought disorders such as schizophrenia. Brief for the American Psychiatric Association and the Washington State Psychiatric Association as Amici Curiae at 2-3 n.1, Washington v. Harper, 494 U.S. 210, 214 (1989) (No. 88-599). Other psychotropic medications include antidepressants and mood stabilizers. These drugs are used to treat mood disorders. See WALDINGER, supra at 397-98. Lithium, for example, is used to treat manic-depressive illness and is classified as a mood stabilizer. See id. at 434. Because civilly committed patients have a right to 
treatment decisions, that is, to weigh the risks, benefits, and alternatives to the proposed medication. ${ }^{96}$ Prisoner mental patients have no such right. The Supreme Court does not deem mentally ill prisoners to be similarly situated with other mental patients. The state's legitimate interest in maintaining prison safety and security applies only to prisoners, not to nonprisoner mental patients. ${ }^{97}$

But even if Harper allows states to distinguish mentally ill prisoners from mentally ill nonprisoners in the procedural protections accorded to a patient's treatment refusal decision, the case is of limited precedential

refuse treatment regardless of whether they have thought or mood disorders, "psychotropic" is the more appropriate word choice.

In the $1990 \mathrm{~s}$, four new psychotropic medications - clozapine, risperidone, olanzapine, and quetiapine-were approved to treat patients with psychotic disorders. These antipsychotic medications are called "novel" or "atypical" agents because they alleviate psychotic symptoms without inducing the extrapyramidal (neuromotor) side effects that typically accompany treatment with conventional medications. See Douglas Mossman, Unbuckling the "Chemical Straitjacket": The Legal Significance of Recent Advances in the Pharmacological Treatment of Psychosis, 39 SAN DIEGO L. REV. 1033, 1039-40, 1069-77 (2002). Although courts have not fully considered the impact of these new medications on patients' right to refuse treatment, Mossman asserts: "[I]t seems very unlikely that courts will undo the cautions and procedural protections embodied in litigation that addressed involuntary treatment with older, more noxious antipsychotic drugs." Id. at 1148 .

96. Courts in many states have held that civilly committed mental patients have a right to refuse psychotropic medication in the absence of an adjudication that they are incompetent to make treatment decisions. See, e.g., Riese v. St. Mary's Hosp. \& Med. Ctr., 271 Cal. Rptr. 199, 201, 210 (Ct. App. 1987) (holding that in nonemergency situations, antipsychotic medication cannot be administered to involuntarily committed civil patients without their consent absent a judicial determination of their incapacity to make treatment decisions); Rogers v. Comm'r, 458 N.E.2d 308, 314 (Mass. 1983) (holding that involuntarily committed civil patients do not lose the right to make treatment decisions unless they are adjudicated incompetent by a judge in incompetency proceedings); Rivers v. Katz, 495 N.E.2d 337, 342-44 (N.Y. 1986) (holding that involuntary civil commitment, without more, does not establish that the committed person lacks the mental capacity to comprehend the consequences of medication refusal decisions and that a judicial determination that the patient lacks that capacity is required before the state may administer antipsychotic drugs over the patient's objection). Utilizing the informed consent doctrine, "virtually every court that has considered the matter now recognizes a 'right to refuse' psychotropic medication for institutionalized populations.” Ralph Reisner et AL., LaW AND the Mental Health System: Civil and CRIMINAL ASPECTS 885 (3d ed. 1999).

97. For nonprisoner mental patients, however, the state could claim a legitimate interest in maintaining the safety and security of the mental hospital. Would the state's obligation to provide a safe environment for all involuntarily detained mental patients and for the employees at that hospital permit it to authorize involuntary administration of psychotropic medication without a judicial determination of the patient's incompetence to refuse that medication? In Harper, the Supreme Court noted that the prison regulation in question used definitions of "mental disorder," "gravely disabled," and "likelihood of serious harm" that were identical to the definitions used in the state's civil commitment statute. Harper, 494 U.S. at 215 n.3. Do these similarities suggest that the adoption of the same regulation for nonprisoner mental patients would satisfy minimum federal constitutional requirements? Harper provides no definitive answer. 
value in determining whether mentally ill prisoners can be distinguished from mentally ill nonprisoners for imposing criminal liability if the patient escapes. Although the prisoner is under criminal sentence at the time he escapes, the prisoner is not escaping from a prison at which he is being punished, but rather from a mental hospital at which he is being treated. Who presents a greater danger to society, a prisoner-escapee who was medicated over his objection because such treatment was in his medical interest and was necessary to reduce his potential for danger, ${ }^{98}$ or a nonprisoner-escapee who was civilly committed because he was dangerous and who was not medicated over his objection because he was competent to refuse it? Obviously, the unmedicated nonprisonerescapee is more dangerous.

Can it be argued that the state's reversionary interest in resuming the convict's punishment once his mental condition improves enough to permit retransfer to prison justifies criminalizing his escape prior to such improvement? It could, perhaps, if the prisoner escaped to avoid retransfer to prison and resumption of punishment. But the crime of escape does not require such a finding. If prisoner mental patients are punished for escaping from a mental hospital when nonprisoners are not, they are punished because of their status as prisoners, even though their transfer into the hospital was premised on their mental condition, not their prisoner status.

The individual's status as a prisoner, and the state's legitimate penological interest in punishing prisoners, appears to provide the only justification for laws that typically punish prisoners, but not civilly committed mental patients, when they escape from custody. Although the distinction appears sound when applied to a nonmentally ill prisoner who escapes from the custody of a prison, it is far more questionable when applied to a severely mentally ill prisoner who has been transferred to a mental hospital for treatment and who escapes from that facility.

\section{ESCAPE BY “SPECIAL” CIVILLY COMMITTED NONCONVICTS}

Part III assumes that, despite the concerns raised above, courts will

98. In Harper, the Supreme Court upheld a prison regulation that authorized the administration of antipsychotic medication over the prisoner's objection if the prisoner was dangerous to himself or others and the treatment was in the prisoner's medical interest. Id. at 227; see supra note 85 and accompanying text. 
continue to criminalize escape by mentally ill prisoners from mental hospitals, even though escape by civilly committed, mentally ill nonprisoners is not criminalized. This Part considers whether certain specially categorized patients should be equated to mentally ill criminals, and therefore subject to prosecution for escape, or whether they should be equated to regular, civilly committed patients, and not subject to prosecution for escape.

\section{A. Sentence-Expiring Convicts}

In 1966, in the case of Baxstrom v. Herold, ${ }^{99}$ the Supreme Court held unconstitutional a New York statute that authorized, through administrative decision, the civil commitment of mentally ill, sentence-expiring convicts and their continued confinement in a maximum security mental institution operated by the Department of Correction. ${ }^{100}$ Under the statute, sentenceexpiring convicts were the only persons subject to civil commitment who were denied a jury review on the question of whether their mental condition met the civil commitment criteria. They were also the only persons who were denied court hearings on the question of whether they were dangerously mentally ill, a prerequisite for confinement in a Department of Correction maximum security mental institution. ${ }^{101}$ Writing for a unanimous Court, ${ }^{102}$ Chief Justice Warren rejected the assertion that a person's criminal tendencies or dangerous propensities are established by his past criminal record. ${ }^{103}$ Equal protection "demands" procedural safeguards that all others receive in the civil commitment process; they cannot be specially classified to avoid the standard procedural roadblocks to civil commitment. ${ }^{105}$ Equal protection also demands that they receive the same procedural safeguards that all other civilly committed patients receive before they may be placed in maximum security confinement - they cannot be specially classified to avoid the standard roadblocks to such placement. ${ }^{106}$ "[T] conceivable basis," wrote Chief Justice Warren, "for distinguishing the commitment of a person who is nearing the end of a penal term from all other civil commitments." 107

\footnotetext{
99. 383 U.S. 107 (1966).

100. Id. at $110-11$.

101. Id. at $110-13$.

102. Justice Black concurred in the result but wrote no opinion. Id. at 115 .

103. Id. at 114 .

104. "Demands" was the word choice of the Chief Justice. Id. at 115.

105. Id. at $110,114-15$.

106. Id.

107. Id. at $111-12$.
} 
Although the Baxstrom Court considered only a sentence-expiring convict's right to procedural protections in the civil commitment process and in decisions to place the patient in maximum security confinement, ${ }^{108}$ just six years later, the Court construed its Baxstrom precedent broadly, stating: "Baxstrom held that the State cannot withhold from a few the procedural protections or the substantive requirements for commitment that are available to all others." 109 If convicts were to be civilly committed upon expiration of their criminal sentences, the state was required to use the same civil commitment statutes - the same procedures and same criteria - used to civilly commit any other person and to commit them to mental hospitals operated by the Department of Mental Hygiene, rather than hospitals operated by the Department of Correction. They could not be separately categorized for civil commitment purposes. ${ }^{110}$ After all, when a prisoner's sentence

108. See Humphrey v. Cady, 405 U.S. 504, 506-08 (1972). In Humphrey, the Supreme Court applied its Baxstrom precedent to an individual convicted of the misdemeanor of contributing to the delinquency of a minor. In lieu of a one-year maximum sentence, he was committed pursuant to the Wisconsin Sex Crime Act to the sex deviate facility in the state prison for a potentially indefinite period, that is, initial commitment for a period equal to the maximum sentence followed by renewable fiveyear commitment periods. Id. at 506-07. The Court ruled that petitioner's contention that he was denied equal protection in the renewal commitment, which did not accord him a jury trial accorded other persons undergoing civil commitment, was substantial enough to warrant an evidentiary hearing in a federal habeas corpus proceeding. Id. at 508.

109. Jackson v. Indiana, 406 U.S. 715, 727 (1972) (emphasis added).

110. As a result of the Baxstrom decision, nearly 1000 sentence-expiring prisoners were discharged from confinement under the unconstitutional law that mandated their placement in maximum security mental hospitals administered by the Department of Correction. Almost all of the 992 Baxstrom patients were civilly committed-using the criteria and procedures applicable to all other patients who were civilly committed - and placed in Department of Mental Hygiene mental hospitals. Within a six-month period, 79 were discharged to the community, 22 were conditionally released on convalescent care, 273 were reclassified to voluntary patient status, and 24 were reclassified to informal patient status. Only six had to be transferred back to maximum security hospitals operated by the Department of Correction as dangerously mentally ill. Within the following six months, an additional sixty-eight Baxstrom patients were discharged and only one was transferred to a maximum security hospital. Morris, supra note 67, at 793-95. The results strongly suggest that psychiatrists: (1) overpredict dangerous mental illness, (2) are unwilling to accept and treat as mental patients those who are identified as "dangerous" or labeled as "criminals," and (3) have the ability to treat such patients when they are integrated with and given treatment indistinguishable from that provided to other civilly committed mental patients. Id. at 796; see also HENRY J. STEADMAN \& JosePH J. COCOZZA, CAREERS OF THE CRIMINAlly InSANE 55-161 (1974) (finding that the Baxstrom patients were not very dangerous and were successfully treated in civil mental hospitals and that, when released to the community, few displayed dangerous behavior); Morris, supra note 66, at 670-75. 
expires, his debt to society has been paid, and the prisoner is no longer subject to further punishment.

If no conceivable basis exists for distinguishing the commitment of sentence-expiring convicts from all other civil commitments-if sentence-expiring convicts cannot be separately categorized for civil commitment purposes - then no conceivable basis exists for distinguishing sentence-expiring convicts from other civilly committed patients when they escape from a mental hospital. If other civilly committed patients are not prosecuted for such conduct, these civilly committed patients should not be prosecuted. To do otherwise would violate equal protection of the laws.

Although Baxstrom was decided more than thirty-six years ago, it is not just a viable precedent, it is a venerable precedent. Baxstrom has been cited in over 500 court decisions, including eighteen Supreme Court decisions. ${ }^{11}$ In many states, statutes specifically mandate use of the regular civil commitment process to confine a prisoner at the completion of his penal sentence. ${ }^{112}$ Occasionally, however, a state enacts statutes that ignore, if not repudiate, the Baxstrom holding. California, for example, has enacted statutes, ${ }^{113}$ commonly referred to by courts ${ }^{114}$ and commentators ${ }^{115}$ as mentally disordered offenders statutes. Despite this characterization, the statutes are applicable, not to sentence-serving offenders, but rather as a condition of parole to sentence-expiring offenders who are about to be discharged from prison. ${ }^{116}$ If a court or jury finds that the person has a severe mental disorder that is not in remission or cannot be kept in remission without treatment, and that the person represents a substantial danger of physical harm to others because of that disorder, the person can be committed for renewable one-year periods. ${ }^{117}$

In a statement of legislative findings and declarations, the California Legislature justified its special classification of mentally disordered, sentence-expiring prisoners by asserting that if the prisoners' severe

111. See Baxstrom v. Herold, 383 U.S. 107 (1966) (WL KeyCite performed Mar. 22, 2002). The Supreme Court most recently cited Baxstrom in Kansas v. Hendricks, 521 U.S. 346 (1997). Justice Thomas, who wrote the Court's majority opinion in Hendricks, cited Baxstrom, id. at 369-70, as did Justice Kennedy, who wrote a concurring opinion, $i d$. at 372 (Kennedy, J., concurring).

112. See, e.g., Ariz. Rev. Stat. AnN. § 31-226(H) (West 2002); Мich. Сomp. LAWS ANN. § 330.2006(3) (West 1996); Mo. ANN. STAT. § 552.050(5) (West 2002).

113. CAL. Penal Code $\S \S 2960-2981$ (West $2000 \&$ Supp. 2003).

114. People v. Fernandez, 82 Cal. Rptr. 2d 469, 471, 475-78 (Ct. App. 1999); People v. Jenkins, 41 Cal. Rptr. 2d 502 (Ct. App. 1995); People v. Coronado, 33 Cal. Rptr. 2d 835 (Ct. App. 1994).

115. See, e.g., M.R. Carrillo-Heian, The Mentally Disordered Offenders Law: The Legislature Responds to People v. Anzalone, 31 McGEORGE L. REV. 276, 276-84 (2000).

116. CAL. Penal Code $§ 2962$ (West Supp. 2003).

117. Id. § 2972(c), (e). 
mental disorders are not in remission or cannot be kept in remission when the prisoners are discharged, "there is a danger to society, and the state has a compelling interest in protecting the public."118 Despite this rhetoric, the legislature failed to explain why that danger is any different, or any greater, than the danger posed by regular civilly committed patients or why the regular civil commitment process does not satisfy the state's compelling interest in protecting the public from that danger.

In fact, regular civilly committed patients may present an even greater danger than do special civilly committed, sentence-expiring prisoners. To be subjected to a 180-day renewable commitment hold in California, the nonprisoner must have attempted, inflicted, or made a serious threat of substantial physical harm upon another person that either resulted in the nonprisoner's detention for evaluation and treatment or that occurred during such detention, and the nonprisoner must continue to present a demonstrated danger of inflicting substantial physical harm upon others. ${ }^{119}$ Although the "substantial danger of physical harm to others" commitment criterion is the same for both groups, sentence-expiring prisoners are subject to "special" civil commitment without any requirement that they engaged in a recent dangerous act or made a serious threat to do so. And yet, even without such proof, the statute authorizes sentence-expiring mentally ill prisoners to be confined for longer periods (renewable, one-year periods) than are demonstrably dangerous, "regular" civilly committed patients (renewable, 180-day periods). Additionally, unlike "regular" civilly committed patients who typically begin their involuntary detention in community treatment centers located in the county of their residence, ${ }^{120}$ sentence-expiring prisoners begin their "civil" commitment in isolated, maximum security, state mental hospitals, such as Atascadero and Patton. ${ }^{121}$

California's attempt to create a separate commitment category for sentence-expiring mentally ill convicts should not withstand an equal protection challenge. Baxstrom simply cannot be ignored. Ironically, another California statute specifically authorizes the Director of Corrections to initiate the regular civil commitment process for

118. Id. § 2960 (West 2000).

119. CAL. Welf. \& INST. CODE $§ 5300$ (West 1998).

120. See id. $\S 5150$ (evaluation and treatment for seventy-two hours); id. $\S 5250$ (certification for fourteen days of intensive treatment).

121. Of the 1085 patients confined in Atascadero State Hospital on July 24, 2002, a total of 317 were either adjudicated as mentally disordered offenders or were being evaluated and processed as mentally disordered offenders. See supra note 16. 
sentence-expiring convicts who are dangerous to others, dangerous to themselves, or gravely disabled as a result of mental disorder, that is, if their mental condition meets the regular civil commitment criteria in California. ${ }^{122}$ This statute is a far more appropriate vehicle for processing any civilly committable, sentence-expiring prisoner.

\section{B. Criminal Defendants}

The government has a fundamental interest in trying a defendant for conduct that it alleges is criminal. ${ }^{123}$ As Justice Brennan stated: "Constitutional power to bring an accused to trial is fundamental to a scheme of 'ordered liberty' and prerequisite to social justice and peace." 124 Incapacitation of dangerous offenders is not the government's sole penological interest. Rather, as explained by the Court of Appeals for the District of Columbia Circuit, "the retributive, deterrent, communicative, and investigative functions of the criminal justice system ... serve to ensure that offenders receive their just deserts, to make clear that offenses entail consequences, and to discover what happened through the public mechanism of trial." 125

Although pretrial detention of arrestees is an exception to the societal norm of liberty, ${ }^{126}$ the Supreme Court upheld a federal statute that denies bail and imposes pretrial detention not merely when the detainee presents a flight risk, but also when the detainee presents a danger to another person or to the community. ${ }^{127}$ In appropriate circumstances, the Court noted, the individual's liberty interest can be outweighed by the government's interest in community safety. ${ }^{128}$ Although the Court characterized as "compelling" the government's general interest in preventing crime, that interest is heightened when the government establishes that the person it seeks to detain has been charged with a serious crime and "presents a demonstrable danger to the community."

122. Cal. Penal Code $\S 2974$ (West 2000).

123. United States v. Gomes, 289 F.3d 71, 80 (2d Cir. 2002). The Supreme Court has described society's interest in finding, convicting, and punishing those who violate the law as a "compelling interest." Moran v. Burbine, 475 U.S. 412, 426 (1986).

124. Illinois v. Allen, 397 U.S. 337, 347 (1970) (Brennan, J., concurring).

125. United States v. Weston, 255 F.3d 873, 882 (D.C. Cir. 2001), cert. denied, 534 U.S. 1067 (2001).

126. United States v. Salerno, 481 U.S. 739, 755 (1987).

127. Id. The Court upheld the constitutionality of a provision of the Bail Reform Act of 1984, id., that provides: "If, after, a hearing ...., the judicial officer finds that no condition or combination of conditions will reasonably assure the appearance of the person as required and the safety of any other person and the community, such judicial officer shall order the detention of the person prior to trial," 18 U.S.C. $\S 3142$ (e) (2000).

128. Salerno, 481 U.S. at 748.

129. Id. at 750 . 
In that context, "society's interest in crime prevention is at its greatest." 130

Because a person may, in some situations, be lawfully detained pending trial, escape from lawful custody prior to conviction may constitute the crime of escape. ${ }^{131}$ In fact, many jurisdictions specifically include within the statutorily prohibited conduct escape from custody by virtue of arrest for or conviction of a crime. ${ }^{132}$

\section{Mentally Incompetent Criminal Defendants}

If a defendant is mentally incompetent to stand trial, that is, is unable to understand the criminal proceedings or to assist counsel in his defense, ${ }^{133}$ the trial is suspended until the defendant's competence has been restored. ${ }^{134}$ In fact, the Supreme Court has ruled that the prohibition against conducting a criminal trial of an incompetent defendant "is fundamental to an adversary system of justice." 135 To assure that an incompetent defendant is not deprived of the due process right to a fair trial, ${ }^{136}$ the defense attorney, the prosecutor, and the court all have an obligation to raise the issue whenever reasonable cause exists

130. Id.

131. See supra note 42 and accompanying text.

132. See, e.g., 18 U.S.C. $\S 751$ (2000); ARIZ. REV. STAT. ANN. §§ 13-2502 to -2503 (West 2001 \& Supp. 2002); IowA CoDE ANN. § 719.4(1) (West Supp. 2003); N.J. STAT. ANN. § 2C:29-5(a) (West 1995); N.Y. PENAL LAW §§ 205.00-.15 (McKinney 1999); 18 PA. Cons. Stat. AnN. § 5121 (West 1983); WASH. Rev. Code § 9A.76.120 (West Supp. 2003); Wis. STAT. ANN. § 946.42(2)(a), (3)(a) (West Supp. 2002).

133. See 18 U.S.C. $\$ 4241$ (a) (2000).

134. See id. $\$ 4241(\mathrm{~d})$.

135. Drope v. Missouri, 420 U.S. 162, 172 (1975).

136. The suspension of criminal proceedings is warranted to assure the accuracy, fairness, and dignity of the trial process and to justify the imposition of punishment if the defendant is convicted. In many cases, the accused may be the only individual who has knowledge of the facts underlying the criminal charge, and thus, an accurate assessment of guilt requires the defendant's assistance. To assure fairness in the criminal process, the accused must have the basic capacity to assist counsel in presenting a defense. The dignity of the criminal process would be undermined by the spectacle of an incompetent defendant's trial. The objective of punishment requires that a convicted defendant comprehend the reasons why the court is imposing punishment. Barbara A. Weiner, Mental Disability and the Criminal Law, in AM. BAR Found., THE MenTALly DisABLed AND THE LAW 693, 694 (Samuel J. Brakel et al. eds., 3d ed. 1985); Note, Incompetency to Stand Trial, 81 HARV. L. REV. 454, 457-59 (1967). The suspension of criminal proceedings against incompetent defendants is "a by-product of the ban against trial in absentia; the mentally incompetent defendant, though physically present in the courtroom, is in reality afforded no opportunity to defend himself." Caleb Foote, A Comment on Pre-Trial Commitment of Criminal Defendants, 108 U. PA. L. REv. 832, 834 (1960). 
to believe that the accused is mentally incompetent. ${ }^{137}$

If a mentally incompetent defendant escapes from custody during the period he is undergoing treatment to restore competency, ${ }^{138}$ may he be prosecuted for the crime of escape if ordinary civilly committed patients are not? The issue has not received appellate court attention. Perhaps prosecutions for such escapes are rare. After all, to be adjudicated incompetent to stand trial, the defendant's mental condition must be impaired to such an extent that he is unable to understand the nature of the criminal proceedings or to assist counsel in defending against the criminal charges. A New York City Criminal Court judge noted that prosecution of an incompetent defendant for escape would be futile and unjust because that act was likely to be related to the defendant's incompetency. ${ }^{139}$ The court suggested that such prosecution would be "pointless" because the defendant "would likely not be competent to stand trial in a new action for escape." 140

If the defendant is mentally incompetent to stand trial at the time of escape, then a defense of insanity for the crime of escape may well be viable. ${ }^{141}$ If a defendant does not even know what a criminal trial is all

137. In Pate v. Robinson, 383 U.S. 375 (1966), the Supreme Court stated: "Where the evidence raises a 'bone fide doubt' as to a defendant's competence to stand trial, the judge on his own motion must impanel a jury and conduct a sanity hearing ...." Id. at 385. The American Bar Association, in its Criminal Justice Mental Health Standards approved by the ABA House of Delegates in August 1984, adopted a standard requiring the prosecutor and the defense counsel to move for the evaluation of the defendant's competence whenever the prosecutor or the defense counsel has a good faith doubt as to the defendant's competence. ABA Criminal Justice Mental Health Standards standard 7-4.2 (b), (c) (1989).

138. Once the issue of competency to stand trial is raised, the court may order the defendant detained for an evaluation of his mental condition. See, e.g., 18 U.S.C. $\S 4241$ (b) (2000). A defendant who escapes from custody while so detained may be prosecuted for the crime of escape. Similarly, a defendant who escapes from custody when any other mental condition is being evaluated, such as an insanity evaluation that assesses the defendant's mental condition at the time of the criminal act, is subject to prosecution for the crime of escape. Because these individuals have not been committed for treatment of their mental disorder, they cannot be equated to other mental patients - whether civilly committed nonprisoners or sentence-serving prisoners transferred from prison to a mental hospital - when they escape. Although a defendant whose mental status is being evaluated is not by that status alone a prisoner who is subject to punishment, the defendant is in custody and can be required to undergo the evaluation. Therefore, a defendant who escapes in order to avoid either that evaluation or subsequent trial is subject to prosecution for the crime of escape just as are other defendants who escape lawful detention prior to trial. See supra notes 131-32 and accompanying text.

139. People v. Williams, 504 N.Y.S.2d 339, 342 (Crim. Ct. 1986).

140. Id. at 341 .

141. If the insanity defense is available for other crimes, it is available for the crime of escape. See, e.g., United States v. Wood, 628 F.2d 554, 555-56 (D.C. Cir. 1980) (per curiam). In Wood, an individual was confined in St. Elizabeths Hospital after being acquitted of a crime by reason of insanity. He escaped and was prosecuted for the crime of escape. $I d$. at 555. At trial, he relied upon the insanity defense. Id. at 556; see also 
about - that the defendant is charged with a crime, that the trial is a process to determine the defendant's guilt or innocence, that the prosecutor will offer evidence in an attempt to find the defendant guilty, that the defendant will be represented by counsel who will challenge the prosecutor's evidence and offer evidence in an attempt to find the defendant not guilty, that a verdict of guilty will result in the imposition of punishment on the defendant - then it is quite possible that the incompetent defendant who escapes does not know, at the time of escape, the nature and quality of the act or that it was wrong to commit that act. At a minimum, evidence that supported the adjudication of defendant's incompetence to stand trial is probative on the defendant's insanity at the time he escaped. ${ }^{142}$

Although incompetent defendants have not been convicted of crimes and thus are not mentally ill prisoners, the state's interest in restoring trial competence has been used to distinguish these individuals from other civilly committed patients. For example, even though civilly committed patients have a right to refuse psychotropic medication unless they lack the capacity to make treatment decisions, ${ }^{143}$ recent federal court of appeals decisions from the District of Columbia Circuit ${ }^{144}$ and the Eighth ${ }^{145}$ and Second Circuits ${ }^{146}$ permit the government to forcibly medicate incompetent defendants if the medication is both appropriate and necessary to restore competence to stand trial. Ironically, these cases rely upon language in Riggins $v$. Nevada, ${ }^{147}$ a Supreme Court decision that reversed the conviction of a mentally competent defendant who was involuntarily medicated during his criminal trial. The record failed to establish that the administration of psychotropic medication was necessary to accomplish an essential state policy that would permit

United States v. Tate, 419 F.2d 131, 132-33 (6th Cir. 1969) (holding that an indigent defendant who claims insanity as a defense to the charge of escape is entitled to a psychiatric examination at government expense).

142. In Godinez v. Moran, 509 U.S. 389 (1993), the Supreme Court held that a trial court's finding, based on psychiatric reports, that the defendant was competent to stand trial was not only probative, it was determinative of the defendant's competency to plead guilty or to waive the right to counsel. See id. at 395-401.

143. See supra note 96.

144. United States v. Weston, 255 F.3d 873, 882-87 (D.C. Cir.), cert. denied, 534 U.S. 1067 (2001).

145. United States v. Sell, 282 F.3d 560, 567-71 (8th Cir.), cert. granted, 123 S. Ct. $512(2002)$.

146. United States v. Gomes, 289 F.3d 71, 86-87 (2d Cir. 2002).

147. 504 U.S. 127 (1992). 
the state to override the defendant's liberty interest in freedom from unwanted medication ${ }^{148}$ and his Sixth and Fourteenth Amendment rights to a fair trial. ${ }^{149}$

The Riggins majority did not delineate with finality the substantive standards that govern the forced medication of criminal defendants. ${ }^{150}$ The majority did, however, suggest a standard that "certainly would . . . satisf[y] due process." $" 151$ Citing its Harper decision, ${ }^{152}$ the majority stated that due process would be satisfied if the trial court finds that the compelled treatment is "medically appropriate and, considering less intrusive alternatives, essential for the sake of [the defendant's] own safety or the safety of others." 153 Additionally, the majority opined that due process "might" be satisfied if the compelled treatment is medically appropriate and an adjudication of guilt or innocence cannot be obtained using less intrusive means. ${ }^{154}$ Although the Court acknowledged that this gratuitous comment involved speculation on a question that was not before the Court for decision, ${ }^{155}$ other courts, quoting that comment, ${ }^{156}$ cite Riggins as authority supporting the involuntary medication of incompetent criminal defendants to achieve the state's interest in restoring their trial competence. ${ }^{157}$ The Supreme Court has recently agreed to consider whether involuntarily medicating an incompetent defendant to restore competency to stand trial for nonviolent offenses violates the defendant's constitutional rights. ${ }^{158}$

148. Id. at $137-38$

149. Id. at $132-38$.

150. Id. at 136. The Court specifically noted that it had "not had occasion to develop substantive standards for judging forced administration of [antipsychotic] drugs in the trial or pretrial settings." Id. at 135. In his dissenting opinion, Justice Thomas asserted that the Riggins majority "appears to adopt a standard of strict scrutiny." Id. at 156 (Thomas, J., dissenting). The majority denied the assertion. Id. at 136.

151. Id. at 135 .

152. Washington v. Harper, 494 U.S. 210 (1990); see supra notes 84-94 and accompanying text.

153. Riggins, 504 U.S. at 135.

154. Id.

155. Id. at 136. Because Riggins did not claim a right to discontinue psychotropic medication if its administration was necessary to continue his competence to stand trial, the Court specifically refused to consider whether Riggins, or any competent criminal defendant, had such a right. Id. Justice Kennedy, author of the majority's Harper decision, wrote a concurring opinion in Riggins expressing doubt that the state's interest in conducting a trial allows it to involuntarily medicate a defendant to assure his competence to stand trial. Id. at 138-45 (Kennedy, J. concurring).

156. United States v. Gomes, 289 F.3d 71, 81 (2d Cir. 2002); United States v. Sell, 282 F.3d 560, 566 (8th Cir.), cert. granted, 123 S. Ct. 512 (2002); United States v. Weston, 255 F.3d 873, 879 (D.C. Cir.), cert. denied, 534 U.S. 1067 (2001).

157. See supra notes 143-47 and accompanying text.

158. Sell, $123 \mathrm{~S}$. Ct. at 512. The Supreme Court granted certiorari for the limited purpose of considering the following question: "Whether the Court of Appeals erred in rejecting petitioner's argument that allowing the government to administer anti-psychotic 
Even if temporarily incompetent criminal defendants do not have a right to refuse psychotropic medication and thus can be distinguished from civilly committed patients who have such right, can they be distinguished from civilly committed patients for other purposes, including prosecution for the crime of escape? If danger to society is the justification for criminal prosecution, the patient who was civilly committed as dangerous to society and who was not medicated over his objection because the patient was competent to refuse medication presents a greater danger through escape than does an involuntarily medicated criminal defendant. The defendant was confined because he was incompetent to stand trial, not because he was too dangerous to live in society.

I previously argued that the state's interest in resuming a mentally ill convict's punishment once his mental condition improves does not justify criminalizing his escape prior to such improvement. ${ }^{159}$ Similarly, the state's interest in trying an incompetent criminal defendant once the defendant has been restored to competency does not justify criminalizing his escape prior to such restoration. Both have been hospitalized for treatment of their mental condition, not for punishment. Their status, while in that hospital, is patient, not prisoner.

In fact, incompetent defendants have a stronger argument against prosecution for escape than do mentally ill convicts. Although convicts face the certainty of punishment when their mental condition improves, criminal defendants face only the prospect of criminal trial upon restoration to competency. Punishment for criminal defendants is appropriate only if they are found guilty in those trials. If civilly committed patients are not prosecuted for the crime of escape, incompetent criminal defendants - individuals whom the law presumes to be innocent until they are proven guilty - should not be prosecuted for the crime of escape. Although mentally incompetent criminal defendants can be detained to restore their competence and although they face a criminal trial if their competence is restored, they do not become convicts unless and until they are convicted. Unless and until that event occurs, they should be considered to be civil patients, not convict patients.

medication against his will solely to render him competent to stand trial for non-violent offenses would violate his right under the First, Fifth, and Sixth Amendments." Id.

159. See supra text following note 98 . 


\section{Permanently Incompetent Criminal Defendants}

Prior to 1972, criminal defendants found mentally incompetent to stand trial were confined for an indeterminate period until their competence was restored. ${ }^{160}$ For many, "a finding of incompetence to stand trial was tantamount to a life sentence." "161 In Jackson v. Indiana ${ }^{162}$ however, a unanimous ${ }^{163}$ Supreme Court invalidated a statute that permitted the indeterminate - and potentially lifetime - commitment of a mentally retarded, deaf mute person who had been found incompetent to stand trial. ${ }^{164}$ The Court ruled that the Baxstrom principle is not limited to sentence-expiring convicts, but applies as well to incompetent criminal defendants: "If criminal conviction and imposition of sentence are insufficient to justify less procedural and substantive protection against indefinite commitment than that generally available to all others, the mere filing of criminal charges surely cannot suffice."165 Equal protection is denied when incompetent criminal defendants are subjected to a more lenient commitment standard (that is, incompetence to stand criminal trial) and to a more stringent release standard (that is, restoration of trial competence) than is applicable to all other persons who are not charged with crimes and who could only be detained under the state's civil commitment laws. ${ }^{166}$ Although the finding of incompetence to stand trial may justify a brief period of detention designed to restore the defendant's competence, due process requires that incompetent defendants who cannot soon be restored to competency must be released or subjected to "the customary civil commitment proceeding that would be required to commit indefinitely any other citizen."167 Although the Court declined to specify when civil commitment or release must occur,

160. A 1965 study of Matteawan State Hospital, a maximum security institution administered by the New York State Department of Correction, revealed that 208 of the 1062 mentally incompetent defendants at that facility had been detained there for twenty years or more. SPecial Comm. ON THe Study of Commitment Procedures \& THE LaW RElAting to InCOMPETENTS, Ass'N OF THE BAR OF the City OF N.Y., MENTAL ILlNESS, Due Process and the Criminal Defendant $72-73$ (1968). The patient longest in residence at Matteawan at that time was an eighty-three year old patient who had been accused of burglary in 1901 and who had been found mentally incompetent to stand trial. $I d$. at 72. After sixty-four years of confinement at Matteawan, he was, at least theoretically, still awaiting restoration to competence so that he could undergo a criminal trial.

161. Grant H. Morris \& J. Reid Meloy, Out of Mind? Out of Sight: The Uncivil Commitment of Permanently Incompetent Criminal Defendants, 27 U.C. DAVIS L. REV. 1, 4 (1993).

162. 406 U.S. 715 (1972)

163. Justice Powell and Justice Rehnquist did not participate in the Court's consideration of, or decision in, the case. Id. at 741 .

164. Id. at $717-19,738$.

165. Id. at 724 .

166. See id. at 730

167. Id. at 738 . 
the Court noted that detention of incompetent defendants is appropriate only for those who "probably soon will be able to stand trial."168 And even for those defendants, the Court required that commitment "must be justified by progress toward that goal." 169

If permanently incompetent criminal defendants cannot be distinguished from others who are subjected to involuntary civil commitment-if they cannot be separately categorized for civil commitment purposes - then they cannot be distinguished from other civilly committed patients when they escape from the mental hospital. They are civil patients. If other civilly committed patients are not prosecuted for the crime of escape, then equal protection insulates incompetent criminal defendant patients from such prosecution.

In applying these principles, a New York appellate court ruled that the state's escape statute, which penalizes escape from a detention facility by a person who has been charged with a felony, ${ }^{170}$ was not applicable to a permanently incompetent criminal defendant who was civilly committed to a mental hospital. ${ }^{171}$ Under the escape statute, a "detention facility" is defined as "any place used for the confinement, pursuant to an order of a court, of a person ... confined pursuant to an order of a court."172 Civil mental patients, however, are not involuntarily committed initially by a court order, but rather upon the certificates of two examining physicians accompanied by an appropriate application. ${ }^{173}$ Citing "the equal protection mandate of Jackson v. Indiana," 174 the court noted that a permanently incompetent defendant is admitted "on the

168. Id. An incompetent defendant can only be held for "the reasonable period of time necessary to determine whether there is a substantial probability that he will attain that capacity in the foreseeable future." Id. If such probability does not exist, the defendant must be released or civilly committed. If such probability does exist, the defendant may be detained for a limited time to attempt to restore his competency. Id.

169. Id.

170. N.Y. Penal LaW $§ 205.15$ (McKinney 1999).

171. See People ex rel. Powell v. Warden, Kings County Hosp., 422 N.Y.S.2d 726, 728-29 (App. Div. 1979).

172. N.Y. Penal LaW $\$ 205.00$ (McKinney 1999); see Powell, 422 N.Y.S.2d at 728.

173. N.Y. Mental Hyg. LaW § 9.27(a) (McKinney 2002); see Powell, 422 N.Y.S.2d at 728-29. The statute provides: "The director of a hospital may receive and retain therein as a patient any person alleged to be mentally ill and in need of involuntary care and treatment upon the certificates of two examining physicians, accompanied by an application for the admission of such person." N.Y. MENTAL HYG. LAW § 9.27(a). A person may be detained for sixty days before judicial approval is required to extend the commitment. See id. § 9.33; Powell, 422 N.Y.S.2d at 729.

174. Powell, 422 N.Y.S.2d at 728. 
same basis provided for any other person, without regard to his status as an accused." ${ }^{175}$ Because there was no court order authorizing confinement of the permanently incompetent criminal defendant at the time he escaped, he did not violate the escape statute. ${ }^{176}$

Although Jackson was decided more than thirty years ago, it too joins Baxstrom, not just as a viable precedent, but as a venerable precedent. Jackson has been cited in over 600 court decisions, including twentyfour Supreme Court decisions. ${ }^{177}$ Nevertheless, a review of legislation in the fifty states and the District of Columbia, conducted twenty years after Jackson v. Indiana was decided, revealed that the Supreme Court's decision has been ignored or circumvented in a majority of jurisdictions. ${ }^{178}$ Some states ignore Jackson by continuing to allow incompetent defendants to be detained until their competence has been restored. ${ }^{179}$ Others evade Jackson by imposing a lengthy period of treatment before acknowledging that the defendant is permanently incompetent, that is, that there is no substantial probability that the defendant will become competent to stand trial in the foreseeable future. ${ }^{180}$ Although this decision can be made within six months or, at most, a year, ${ }^{181}$ Florida, for example, mandates a five-year treatment period for any incompetent felony defendant. ${ }^{182}$ Several states tie the maximum length of the treatment period to the maximum sentence that could have been imposed if the defendant was convicted of the crime charged. ${ }^{183}$

These laws do not conform to the Supreme Court's requirement that conditions an incompetent defendant's treatment on progress toward the goal of restoration to competence. ${ }^{184}$ A defendant charged with a serious

175. Id.

176. Id. at $727-29$.

177. See Jackson v. Indiana, 406 U.S. 715 (1972) (WL KeyCite performed Mar. 22, 2003). The Supreme Court most recently cited Jackson in Zadvydas v. Davis, 533 U.S. 678 (2001), noting that when "detention's goal is no longer practically attainable, detention no longer 'bear[s] [a] reasonable relation to the purpose for which the individual [was] committed." Id. at 690 (quoting Jackson, 406 U.S. at 738).

178. See Morris \& Meloy, supra note 161, at 13-33.

179. Id. at 13 .

180. Id. at $15-18$.

181. See Ronald Roesch \& Stephen L. Golding, Competency to Stand Trial 116-20 (1980). Roesch and Golding discuss twelve proposals to establish durational limits on the treatment of incompetent defendants. Most of the proposals recommended a six-month limitation with a possible six-month extension if a substantial probability exists that competence will be restored within that extension. Id. at 116. Among those who propose such limits is distinguished psychiatrist Alan Stone, M.D., a former President of the American Psychiatric Association and Professor of Law and Psychiatry at Harvard. Alan A. Stone, Mental Health and LaW: A System in Transition 212-13 (1976).

182. FLA. R. CRIM. P. 3.213(a)-(b).

183. See Morris \& Meloy, supra note 161 , at 17-18.

184. Jackson v. Indiana, 406 U.S. 715, 738 (1972); see supra notes 168-69 and accompanying text. See generally 4 Michael L. Perlin, Mental Disability Law: 
crime is not by that fact alone more difficult to treat or less responsive to treatment than a defendant charged with a less serious crime. ${ }^{185}$ Treatment progress simply cannot be measured by the seriousness of the criminal charge or the possible sentence that could be imposed if the defendant were found guilty in a trial that has yet to be held. And yet, these laws allow continued confinement of permanently incompetent criminal defendants even though further treatment will not result in restoration of their competency. "At the least," stated the Court in Jackson, "due process requires that the nature and duration of commitment bear some reasonable relation to the purpose for which the individual is committed." 186 That purpose is restoration to competence, not incapacitation for the length of a maximum sentence that can only be imposed if the defendant is tried and found guilty. ${ }^{187}$

In California, permanently incompetent criminal defendants can be placed on mental health conservatorships using different criteria than are used to establish mental health conservatorships for all other mentally ill people. To establish a mental health conservatorship, the individual must be gravely disabled. ${ }^{188}$ For all other mentally ill people, "gravely disabled" is defined as "a condition in which a person as a result of a mental disorder, is unable to provide for his or her basic personal needs for food, clothing, or shelter." 189 However, for permanently incompetent criminal defendants, "gravely disabled" is defined as a condition in which the person has been found mentally incompetent to stand trial; the indictment or information charges a felony involving death, great bodily injury, or a serious threat to the physical well-being of another; the indictment or information has not been dismissed; and the person is

CIVIL AND CRIMINAL $\S 8 \mathrm{~A}-5.3$, at 70-73 (2d ed. 2002) (characterizing as "pretextuality" the decisions of state courts and legislatures to avoid their Jackson obligations).

185. See RoESCH \& Golding, supra note 181, at 127.

186. Jackson, 406 U.S. at 738.

187. In Minnesota, upon a finding of incompetency to stand trial, the defendant is not committed for the limited purpose of restoring his competency. Upon a finding of incompetence, commitment occurs, if at all, only through the civil commitment process. MinN. R. CRIM. P. 20.01(4). However, if the incompetent defendant is found to have homicidal tendencies, the law requires that the defendant be committed "to the Minnesota Security Hospital for safekeeping and treatment ... until recovery." MINN. STAT. ANN. § 253.25 (West 1998). Thus, for these defendants, indeterminate commitment occurs without any requirement of treatment progress to restore competency. For these defendants, Minnesota violates Jackson's requirements.

188. CAL. WelF. \& INST. CODE $\S 5350$ (West 1998).

189. Id. $\S 5008(\mathrm{~h})(1)(\mathrm{A})$. 
incompetent to stand trial. ${ }^{190}$ Thus, for permanently incompetent criminal defendants, grave disability is not determined by a functional inability to provide for basic needs. Nevertheless, as with other gravely disabled persons placed on conservatorships, permanently incompetent defendant conservatees may be subjected to inpatient commitment at the direction of their conservators. ${ }^{191}$ However, unlike other conservatees who, by law, must be placed in the least restrictive placement, ${ }^{192}$ permanently incompetent criminal defendant conservatees, by law, must be placed in a facility "that achieves the purposes of treatment of the conservatee and protection of the public."193 Other conservatees, if committed at all, are typically placed in community mental treatment facilities; permanently incompetent defendant conservatees are often committed to more secure - and more isolated — state hospitals. ${ }^{194}$ Other conservatees may be transferred by their conservators to alternative placements without any hearing or court approval. ${ }^{195}$ Permanently incompetent criminal defendant conservatees may not be transferred by their conservators to alternative placements unless written notice of the proposed change of placement is provided to the court and to others designated by the statute and by the court to receive notice. If any person receiving such notice objects to the proposed transfer, transfer may not occur without a hearing and court approval. ${ }^{196}$ Court approval may only be given if the conservator proves by a preponderance of the evidence that a less restrictive alternative placement does not pose a threat to the safety of the public, the permanently incompetent criminal defendant, or to any other individual. ${ }^{197}$

Surely, the California approach violates the Jackson requirements. ${ }^{198}$

190. Id. $\S 5008(\mathrm{~h})(1)(\mathrm{B})$.

191. Id. $\S 5358(\mathrm{a})(1)-(2)$.

192. Id. $\S 5358(\mathrm{a})(1)(\mathrm{A})$.

193. Id. § $5358(\mathrm{a})(1)(\mathrm{B})$.

194. On November 6, 2002, thirty-three permanently incompetent criminal defendant conservatees were confined in Patton State Hospital, thirty in Napa State Hospital, and four in Metropolitan State Hospital. E-mail from Barrie Hafler, Public Relations Officer, Atascadero State Hospital, to Grant Morris, Professor of Law, University of San Diego School of Law (Nov. 7, 2002, 10:58:03 PST) (on file with author).

195. Cal. Welf. \& Inst. Code $§ 5358(d)(1)$ (West 1998).

196. Id. § 5358(d)(2).

197. Id. $\S 5358(\mathrm{~d})(3)$. A hearing to consider transfer to a less restrictive alternative placement may not be granted more than once every six months. Id. § 5358(d)(4) (incorporating by reference $i d$. $\S 5358.3$ ).

198. The failure to accord permanently incompetent defendant conservatees the same right to placement in the least restrictive appropriate treatment setting may also violate the requirements of the Americans with Disabilities Act. See Michael L. Perlin, "For the Misdemeanor Outlaw": The Impact of the ADA on the Institutionalization of Criminal Defendants with Mental Disabilities, 52 ALA. L. REV. 193, 232-34 (2000) (asserting that the Supreme Court's decision in Olmstead v. L.C., 527 U.S. 581 (1999), interpreting the ADA, may require individualized placement decisionmaking for 
Jackson specifically prohibits use of a more lenient commitment standard and a more stringent release standard for permanently incompetent criminal defendants than for other persons not charged with crimes. ${ }^{199}$ However, California violates this prohibition. If a defendant is permanently incompetent, Jackson obligates the state either to "institute the customary civil commitment proceeding that would be required to commit indefinitely any other citizen or release the defendant." 200 California fails to meet this obligation. ${ }^{201}$

In states that ignore or evade their Jackson obligation by continuing to detain permanently incompetent defendants as if they were only temporarily incompetent, ${ }^{202}$ a defendant is more likely to be subjected to a criminal prosecution for escape than in states that have properly applied Jackson by acknowledging the indeterminacy of the defendant's condition and then civilly committing him. The nonconforming states have not conceded that the permanently incompetent defendant is a civil patient and that he must be treated in all respects as a civil patient. These states continue to deny that equal protection precludes prosecuting these patients for the crime of escape if other civilly committed patients are not prosecuted for that crime.

To assure that incompetent criminal defendants_-including permanently

permanently incompetent criminal defendants and other forensic patients, rather than uniform placement in maximum security institutions).

199. See Jackson v. Indiana, 406 U.S. 715, 730 (1972); see also supra notes 166-67 and accompanying text.

200. Jackson, 406 U.S. at 738 (emphasis added).

201. But see Conservatorship of Hofferber, 616 P.2d 836 (Cal. 1980). In Hofferber, the California Supreme Court upheld the constitutionality of California's special conservatorship statute for permanently incompetent criminal defendants, but engrafted on the statute a requirement that the trial court find that the incompetent defendant, by reason of mental disorder, represent a substantial danger of physical harm to others. Id. at 846-47. The court asserted that the state "may adopt more than one procedure for isolating, treating, and restraining dangerous persons." Id. at 844 . According to the court, the legislature may establish a short-term civil commitment process for an imminently dangerous person who has not been adjudicated under the criminal justice system and may also establish a separate, longer-term civil commitment process for a permanently incompetent criminal defendant. Id. at 844-46.

Chief Justice Bird dissented, angrily denouncing the court's decision: "It is with considerable bewilderment that one reads today's majority opinion. Explicit words - not to mention fundamental premises - of a United States Supreme Court decision are ignored, as if they do not exist. Firmly established methods of equal protection analysis are fleetingly alluded to and then forgotten." Id. at 852 (Bird, C.J., dissenting). For a more extensive critique of the Hofferber decision, see Morris \& Meloy, supra note 161, at 27-32.

202. See supra notes $178-83$ and accompanying text. 
incompetent criminal defendants - are prosecuted for escape, some state legislatures have not been content to rely upon the general statutory provisions that criminalize escape from custody. Rather, in these states statutes have been enacted specifically targeting escape by hospitalized incompetent criminal defendants. A Florida statute, for example, declares the legislature's intent to establish within the Department of Children and Family Services separate and secure facilities for incompetent criminal defendants who are committed to the Department while under the jurisdiction of the committing court. ${ }^{203}$ Another Florida statute declares: "A defendant involuntarily committed to the department under the provisions of this chapter who escapes or attempts to escape from a facility ... commits a felony...."204 This specialized escape statute appears to apply, not only to temporarily incompetent defendants, but to permanently incompetent defendants as well. The trial court, upon finding that a defendant is permanently incompetent, may order the defendant committed to the Department of Children and Family Services for involuntary hospitalization. ${ }^{205}$

In California, a statute declares that every mentally incompetent defendant who escapes after being committed to a state hospital or other mental health facility is punishable by imprisonment in the county jail or in the state prison. ${ }^{206}$ The statute appears to apply not only to temporarily incompetent defendants, but to permanently incompetent defendants as well. The statute specifically refers to other statutes ${ }^{207}$ that authorize a mental health conservatorship to be established for a permanently incompetent defendant ${ }^{208}$ and authorize the conservator to place the conservatee in a state hospital. ${ }^{209}$

Specialized escape statutes targeting incompetent criminal defendantsespecially permanently incompetent criminal defendants—-betray Jackson's

203. FLA. STAT. ANN. § 916.105(1) (West 2001). The Florida Legislature also expresses its intent to confine within those secure facilities defendants who have been acquitted of felonies by reason of insanity. Id. The Florida Legislature declares that "[s]uch secure facilities shall be designed and administered so that ingress and egress ... may be strictly controlled by staff responsible for security in order to protect the defendant, facility personnel, other clients, and citizens in adjacent communities." Id.

204. Id. § 916.1081.

205. FLA. R. CRIM. P. 3.213(b).

206. CAL. Penal Code $\S 1370.5$ (a) (West 2000).

207. Id. (referring to criminal defendants who have been committed to a state hospital or other mental health facility pursuant to California Penal Code sections 1370 or 1370.01).

208. Id. § 1370(c)(1)-(2) (West Supp. 2003); id. § 1370.01(c)(1)-(2) (West 2000).

209. Sections $1370(\mathrm{c})(2)$ and 1370.01(c)(2) each authorize the initiation of conservatorship proceedings pursuant to Chapter 3 of Part 1 of Division 5 of California's Welfare and Institutions Code, commencing with section 5350. Id. §§ 1370(c)(2), 1370.01(c)(2). Section 5358 of California's Welfare and Institutions Code authorizes the conservator to place the conservatee in a state hospital. CAL. Welf. \& Inst. CODE $\S$ 5358(a)(2) (West 1998) 
promise that such individuals are not distinguishable from other civilly committed individuals. Because other civilly committed patients cannot be prosecuted for escape under these statutes, equal protection prohibits use of such statutes to prosecute permanently incompetent criminal defendants.

\section{Insanity Acquittees}

If sentence-expiring convicts and permanently incompetent criminal defendants cannot be specially classified for civil commitment purposes and cannot be prosecuted for escape when other civilly committed patients are not, then it is logical to assume that no nonconvict can be specially classified for those purposes, even a nonconvict who has been involved in the criminal process. In Jackson, the Supreme Court noted that the Baxstrom principle had been extended to post-trial commitment decisions involving individuals who had been absolved from criminal responsibility by insanity verdicts. ${ }^{210}$ A successful insanity defense precludes criminal responsibility. A seriously mentally disordered person who engages in criminal behavior but who is found not guilty of the crime because of that disorder is not blameworthy and is not subject to criminal punishment. Relying upon Baxstrom, the Court of Appeals for the District of Columbia Circuit ${ }^{211}$ and the highest appellate courts in several states $^{212}$ held that an insanity verdict could not by itself justify the indeterminate detention of an insanity acquittee. Although a finding of insanity at the time of the criminal act warrants a post-trial evaluation of the acquittee's current mental condition, once that evaluation is

210. Jackson v. Indiana, 406 U.S. 715, 724 (1972).

211. Bolton v. Harris, 395 F.2d 642, 649 (D.C. Cir. 1968). Chief Judge Bazelon, writing for the court, relied on Baxstrom as establishing the principle that "the commission of criminal acts does not give rise to a presumption of dangerousness which, standing alone, justifies substantial difference in commitment procedures and confinement conditions for the mentally ill." $I d$. at 647 . To confine an insanity acquittee without affording him the standard civil commitment procedural protections denies him equal protection. See id. at 651-52. The court rejected the argument, which the Supreme Court also rejected in Baxstrom, that expeditious commitment of nonconvict mentally ill persons is justified because of their dangerous or criminal propensities. See $i d$. at 649 . Bolton has been superceded by statute, as stated in United States v. Cohen, 733 F.2d 128, 130-31 (D.C. Cir. 1984). See infra note 215 (discussing the District of Columbia statute that superceded Bolton).

212. See, e.g., State v. Clemons, 515 P.2d 324, 328-29 (Ariz. 1973); Wilson v. State, 287 N.E.2d 875, 881 (Ind. 1972); People v. McQuillan, 221 N.W.2d 569, 579-80, 586 (Mich. 1974); People v. Lally, 224 N.E.2d 87, 92 (N.Y. 1966); State v. Krol, 344 A.2d 289, 297-99 (N.J. 1975); State ex rel. Kovach v. Schubert, 219 N.W.2d 341, 346-47 (Wis. 1974), overruled by State v. Field, 347 N.W.2d 365, 366-67, 372 (Wis. 1984). 
completed, the acquittee should not be distinguished from other nonconvict mentally disordered persons in the criteria applied to the commitment decision and the procedures employed in the commitment process. ${ }^{213}$

Nevertheless, in Jones v. United States, ${ }^{214}$ a narrowly divided Supreme Court held that "insanity acquittees constitute a special class that [can] be treated differently from other candidates for commitment." 215 As a special class, insanity acquittees can be subjected to automatic, indeterminate commitment without first undergoing the civil commitment process. $^{216}$ For civil commitment generally, the state is required to prove, by clear and convincing evidence, that the person is both mentally ill and dangerous. ${ }^{217}$ According to the five-judge Jones majority, the state has no such burden for insanity acquittee commitment. In his criminal trial, Jones pleaded insanity as a defense to the crime charged against him. ${ }^{218}$ The insanity verdict established that he committed a criminal act and that he did so because of mental illness. ${ }^{219}$ The legislature may determine that the insanity verdict supports an inference of continuing mental illness ${ }^{220}$ and continuing dangerousness. ${ }^{221}$ Thus, insanity acquittees can be distinguished from others, such as incompetent criminal defendants, about whom such proof is lacking. ${ }^{222}$

213. See generally Grant H. Morris, Dealing Responsibly with the Criminally Irresponsible, 1982 ARIZ. ST. L.J. 855 (asserting that although insanity acquittees can be subjected to a post-trial evaluation to assess their current mental condition, they should not be distinguished from other nonconvict mentally disordered persons in commitment, release, and treatment decisions).

214. 463 U.S. 354 (1983).

215. Id. at 370 .

216. Id. The District of Columbia statute interpreted in the Jones case provided, and continues to provide, that within fifty days of commitment, a judicial hearing shall be held at which the insanity acquittee can prove his eligibility for release. D.C. CoDE ANN. $\S 24-501(\mathrm{~d})(2)(\mathrm{A})(2001)$ (formerly cited as $\S 24-301(\mathrm{~d})(2)(\mathrm{A})$ ). At that hearing, the burden is placed on the insanity acquittee to prove by a preponderance of the evidence that he "has recovered his sanity and will not in the reasonable future be dangerous to himself or others." Id. § 24-501(d)(1), (d)(2)(B), (e).

217. Addington v. Texas, 441 U.S. 418, 432-33 (1979).

218. Jones, 463 U.S. at 360.

219. See id. at 363.

220. See id. at 366 .

221. See id. at 364 . The Jones majority reasoned that proof of the commission of a criminal act is "concrete evidence" that "may be at least as persuasive as any predictions about dangerousness that might be made in a civil-commitment proceeding." Id.

222. The Court distinguished insanity acquittees from criminal defendants found incompetent to stand trial. Incompetent criminal defendants cannot be committed indefinitely because no affirmative proof has been offered that they committed criminal acts or were dangerous. Id. at 364 n.12 (discussing Jackson v. Indiana, 406 U.S. 715 (1972)).

Some states have enacted statutes that provide for an evidentiary hearing on the question of a permanently incompetent defendant's guilt of the crime charged. If, at that hearing, the defendant is found to have committed a crime, the defendant is subjected to 
In his dissenting opinion, ${ }^{223}$ Justice Brennan noted that an insanity trial focuses on the defendant's mental condition in the past, at the time of the alleged criminal act. It does not provide an adequate basis from which to infer the present and future mental condition of the insanity acquittee. ${ }^{224}$ Insanity acquittees are similarly situated with sentenceexpiring convicts who may "not be treated differently from other candidates for civil commitment." 225 Just as the state bears the burden of proving that sentence-expiring convicts and others subjected to the civil commitment process are currently mentally ill and dangerous, the state should be obligated to prove the same for insanity acquittees. Justice Brennan asserted that the Jones majority did not "purport to overrule Baxstrom or any of the cases which have followed Baxstrom. It is clear, therefore, that the separate facts of criminality and mental illness cannot support indefinite psychiatric commitment, for both were present in Baxstrom."226

additional treatment without undergoing the civil commitment process. See, e.g., 725 Ill. Comp. Stat. ANN. 5/104-25 (West Supp. 2002); N.M. Stat. AnN. § 31-9-1.5 (Michie 2000). Some might assert that, consistent with Jones, the determination of factual guilt in the evidentiary hearing justifies the extended commitment of permanently incompetent criminal defendants. Such statutes, however, do not conform to the requirements of Jackson v. Indiana, 406 U.S. 715 (1972). In Jackson, the Supreme Court declared that the purpose of committing an incompetent is to determine whether the individual will be restored to competency in the near future and if so, to treat the individual toward that end. Jackson, 406 U.S. at 738. No other purpose was identified by the Court in Jackson, and no other purpose has been identified by the Court since it decided Jackson. Because a factual finding of guilt is not related to progress in treatment to restore competence, a factual guilt hearing cannot justify an extended period of treatment. Even if the factual guilt finding could justify placement of incompetent defendants into a special class for commitment purposes initially, the special commitment must end when the justification for that commitment ends. If the incompetent defendant has not progressed toward restoration of competence, the defendant can no longer be committed as an incompetent defendant. Subsequent commitment of the permanently incompetent defendant, if it is to occur at all, must be achieved through the customary civil commitment process used to commit any other citizen. Jackson, 406 U.S. at 738; see Morris \& Meloy, supra note 161, at 18-23 (critiquing the use of evidentiary hearings to establish guilt of permanently incompetent criminal defendants so that they may be detained without customary civil commitment proceedings).

223. Jones, 463 U.S. at 371-86 (Brennan, J., dissenting). Justices Marshall and Blackmun joined in Justice Brennan's dissenting opinion. Id. at 371. Justice Stevens wrote a separate dissent. Id. at 387 (Stevens, J., dissenting).

224. Id. at 377 (Brennan, J., dissenting).

225. Id. at 376 (Brennan, J., dissenting).

226. Id. at 380. In Foucha v. Louisiana, 504 U.S. 71 (1992), the Court held that due process precludes the continued detention of a dangerous, but not mentally ill, insanity acquittee. Id. at 83 . Justice White, who wrote the majority opinion, also addressed the equal protection issue in a portion of the opinion in which three other justices joined. 
American courts have not uniformly decided cases involving the applicability of criminal escape statutes to insanity acquittees. In fact, one justice asserted that "there exists a distinct polarization of views on the issue."227 Some courts have ruled that insanity acquittee escape is not a crime. For example, the Court of Appeals for the District of Columbia Circuit has repeatedly held that the Federal Escape Act requirement that the escape, in order to be unlawful, must be from custody or confinement "by virtue of an arrest on a charge of felony, or conviction of any offense" 228 was not satisfied in cases involving insanity acquittees escaping from St. Elizabeths Hospital. ${ }^{229}$ The verdict acquitting the defendant by reason of insanity terminates the legal vitality of the arrest and does not constitute a criminal conviction. ${ }^{230}$ The court noted that any doubt about its construction of the escape statute is dispelled by the existence of another District of Columbia statute that requires the committing court, upon request of the government, to order the return of the escaped patient to the hospital. ${ }^{231}$

A unanimous Connecticut Supreme Court held that a statute specifically criminalizing escape "from a correctional institution, any public or private, nonprofit half-way house, group home or mental health facility" did not apply to an insanity acquittee who escaped from a locked ward of a mental hospital. ${ }^{232}$ A literal construction of the statute, said the court, would produce the bizarre result that a person who voluntarily admitted himself to a mental hospital would be guilty of a felony if he left that facility without permission. ${ }^{233}$ Therefore, the court

Justice White embraced and applied Justice Brennan's equal protection analysis in Jones. Because the state did not provide for continuing confinement of sentence-expiring convicts who may be dangerous when their sentences expire, it may not continue the confinement of insanity acquittees who may be dangerous but who are no longer insane. $I d$. at 85 . The state lacked a particularly convincing reason for discriminating against insanity acquittees who are no longer mentally ill. $I d$. at 86 . They are similarly situated with sentence-expiring convicts. Id. at 85 . If sentence-expiring convicts cannot be separately categorized for civil commitment purposes, insanity acquittees who are no longer mentally ill cannot be so categorized.

227. People v. Ortega, 487 N.Y.S.2d 939, 945 (Sup. Ct. 1985), aff'd, 499 N.Y.S.2d 1018 (App. Div. 1986), appeal granted, 497 N.E.2d 717 (N.Y. 1988), aff'd, 505 N.E.2d 613 (N.Y. 1987).

228. 18 U.S.C. $\$ 751(2000)$

229. United States v. Powell, 503 F.2d 195, 196 (D.C. Cir. 1974); see United States v. Wood, 628 F.2d 554, 560 (D.C. Cir. 1980) (applying Powell); see also United States v. Snyder, 529 F.2d 871, 872 (D.C. Cir. 1976) (noting that the government concedes that Powell requires reversal of the escape conviction).

230. Powell, 503 F.2d at 196.

231. Id. (quoting D.C. CODE ANN. § 24-301(i) (now codified as D.C. CODE ANN. § 24-501(i) (2001))).

232. State v. Delafose, 441 A.2d 158, 159, 161-63 (Conn. 1981) (quoting ConN. Gen. STAT. AnN. § 53a-169).

233. Id. at 161 . 
examined the legislature's intent in amending the escape statute to include half-way houses, group homes, and mental health facilities as places from which escape is punishable. That purpose was "to impose the same liability for a prisoner's escape from the designated facilities as for the prisoner's escape from the correctional institution from which he had been transferred." ${ }^{234}$ Thus, the statute did not apply to an insanity acquittee because he was not a prisoner under the jurisdiction of the Commissioner of Corrections at the time he escaped. ${ }^{235}$

A New York Supreme Court held that an insanity acquittee's unauthorized departure from a nonsecure mental health facility was not an escape from a "detention facility" as required for criminal liability under the state's felony or misdemeanor escape statutes. ${ }^{236}$ Although the statutory definition of "detention facility" is not limited to a prison but includes any place used to confine a person pursuant to a court order, ${ }^{237}$ the court construed that language to refer to a civil jail used to confine persons in pending civil actions, not to a mental hospital used to confine insanity acquittees and other civilly committed mental patients. ${ }^{238}$ Because the New York Legislature had enacted a separate statute to assure apprehension and return of escaped insanity acquittees but had not specifically imposed criminal penalties on those patients for their escape, the court deemed it inappropriate to impose such sanctions through an expansive interpretation of the more generalized and ambiguous language contained in the existing escape statutes. ${ }^{239}$ Although the court's analysis would preclude inclusion of any mental health facility within the definition of "detention facility," the court bolstered its decision by distinguishing nonsecure facilities, from which the individual in this case escaped, from secure facilities. ${ }^{240}$ Insanity

234. Id. at $161-62$.

235. Id. at 162

236. People v. Ortega, 487 N.Y.S.2d 939, 948-49, 951-52 (Sup. Ct. 1985), aff'd, 499 N.Y.S.2d 1018 (App. Div. 1986), appeal granted, 497 N.E.2d 717 (N.Y. 1988), aff'd, 505 N.E.2d 613 (N.Y. 1987).

237. N.Y. PENAL LAW $\$ 205.00$ (McKinney 1999).

238. Ortega, 487 N.Y.S.2d at 947 (construing N.Y. PENAL LAW § 205.00(1)). The court expressed concern that a literal reading of the statute would allow a criminal prosecution of civilly committed elderly parents or developmentally disabled children who left the mental health facility without authorization. See id. at 946.

239. Id. at 950-52 (discussing N.Y. CRIM. PrOC. LAW § 330.20(19)).

240. Id. at 947-48. The court made this distinction in the event that the legislature "by some strained interpretation" intended to include at least some mental health facilities within the term "detention facility." Id. at 947. 
acquittees placed in nonsecure facilities do not suffer from a dangerous disorder. $^{241}$ In nonsecure facilities, no premium is placed on security and confinement. ${ }^{242}$ "It would be anomalous," said the court, "to apply penal sanctions to a departure from a facility which has, as its primary goal, therapeutic treatment as opposed to confinement." ${ }^{243}$

However, some courts have ruled that insanity acquittee escape is a crime. For example, less than one year after the New York Supreme Court decision discussed above, the appellate division of that court held that a secure mental health facility qualifies as a "detention facility" for the purpose of prosecuting escapes by insanity acquittees. ${ }^{244}$

The Supreme Judicial Court of Maine held that an insanity acquittee who fails to return from a mental health facility furlough commits the crime of escape under a statute that proscribed escape by anyone who was "lawfully detained in any jail or other place of confinement." ${ }^{245}$ The court reasoned that the legislation focused on the lawfulness of the detention, not the reason for the detention. Thus, the statute applied to detentions that were either criminal or civil in nature. ${ }^{246}$ Escape by an insanity acquittee "is an evil to be avoided, not merely because of the threat of violence but also because the judicially sanctioned control of

241. See id. at 948. The New York statutes establish a comprehensive "three-track" procedure for post-verdict disposition of insanity acquittees. If the court finds that the acquittee has a dangerous mental disorder, the acquittee is committed to a secure facility. N.Y. CRIM. PROC. LAW $\S 330.20(1)(f),(6)$ (McKinney 1994). If the court finds that the acquittee does not have a dangerous mental disorder but is mentally ill, the acquittee is civilly committed. Id. $\$ 330.20(6)-(7)$. If the court finds that the acquittee does not have a dangerous mental disorder and is not mentally ill, the acquittee is discharged. Id. $\S$ $330.20(7)$.

242. Ortega, 487 N.Y.S.2d at 948. In contrast, a "secure facility" is defined as one that is "staffed with personnel adequately trained in security methods and so equipped as to minimize the risk or danger of escapes." Id. (citing 14 N.Y COMP. CODES R. \& REGS. tit. $14, \S 541.1(\mathrm{z}))$.

243. Id. at 948

244. People v. Walter, 499 N.Y.S.2d 280, 281 (App. Div. 1986). Although the court discussed Ortega, it did not decide whether a nonsecure facility also qualifies as a "detention facility." Id. The Walter court relied upon its earlier decision in People $v$. Buthy, 446 N.Y.S.2d 756 (App. Div. 1981) (holding that the escape statute applies to an insanity acquittee who escaped from the custody of the Commissioner of Mental Hygiene, who is a public servant under whose restraint the acquittee was placed by court order). Walter, 446 N.Y.S.2d at 282. At the time of the Buthy decision, however, no separate statutory provision existed to assure apprehension and return of escaped insanity acquittees without specifically imposing criminal penalties on them. See id. The Walter court also relied upon People ex rel. Powell v. Warden, Kings County Hosp., 422 N.Y.S.2d 726 (App. Div. 1979) (holding that the escape statute does not apply to a permanently incompetent criminal defendant who was civilly committed to a mental health facility pursuant to the discretionary action of the hospital director rather than pursuant to a court order). Walter, 446 N.Y.S.2d at 282-83; see supra notes 170-76 and accompanying text (discussing Powell).

245. State v. Flemming, 377 A.2d 448, 450-51 (Me. 1977) (interpreting former ME. ReV. Stat. AnN. tit. 17, § 1405, repealed by P.L. 1975, ch. 499, § 7 (1976))

246. Id. at 450 . 
such person is frustrated thereby." 247 Additionally, the statute did not require that the escape be from a penal institution. A mental health facility qualified as an "other place of confinement." 248

The Chief Justice of the Supreme Judicial Court of Maine wrote a separate opinion expressing his disagreement with the court's decision. ${ }^{249} \mathrm{He}$ asserted that the legislature, by eliminating the existing statutory requirement that the person be lawfully detained "for any criminal offense," was merely responding to a decision of the court one year earlier that refused to apply the escape statute to a person charged with, but not yet convicted of, a crime. ${ }^{250}$ The legislature intended to apply the escape law to individuals detained on criminal charges, not to insanity acquittees who are neither charged with nor convicted of crimes. ${ }^{251}$

Some courts have considered broader issues than the statutory construction question of whether insanity acquittees are included as appropriate candidates for escape crime prosecution. For example, even prior to the Jones decision, the supreme courts of Missouri ${ }^{252}$ and Colorado $^{253}$ held that equal protection of the laws is not violated by a statute that criminalizes escape by insanity acquittees but not escape by civilly committed patients. According to the Missouri Supreme Court, to preserve public safety, the state may reasonably distinguish between insanity acquittees, whom the court characterized as "persons having . . . dangerous characteristics or proclivities," 254 and civilly committed

247. Id. at 451 .

248. Id. Eleven years later, the court, relying on its Flemming decision, held that an insanity acquittee's unauthorized departure from a mental health facility constitutes escape from "official custody" in violation of Maine's revised escape statute. State v. Beauchene, 541 A.2d 914, 916-17 (Me. 1988) (construing ME. Rev. StAT. ANN. tit. 17-A, $\S 755)$.

249. Flemming, 377 A.2d at 451-58 (Dufresne, C.J., concurring). Although the Chief Justice expressly stated that he disagreed with the majority's conclusion that an insanity acquittee's escape is within the scope of the escape statute, he nevertheless concurred with the majority's judgment that the trial court erred in dismissing the indictment. $I d$. at 452. That indictment charged the defendant with the common law crime of escape, an offense punishable by a fine of not more than $\$ 500$ or by imprisonment of less than one year. Id. at 457-58.

250. Id. at $455-56$.

251. See id. at 456 .

252. State v. Ewing, 518 S.W.2d 643, 647-49 (Mo. 1975).

253. People v. Giles, 662 P.2d 1073, 1076-77 (Colo. 1983) (en banc). The Colorado Supreme Court also found no violation of the Due Process Clause or the constitutional prohibition against cruel and unusual punishment. Id. at 1075-77.

254. Ewing, 518 S.W.2d at 648. Although the Ewing case involved application of the escape statute to an insanity acquittee, the statute also criminalized escape by 
persons who do not. ${ }^{255}$ The Colorado Supreme Court asserted that "the statutory procedures for civil commitment are not intended to apply to those persons whose illness has resulted in criminal conduct." 256 In contrast, an insanity acquittee has engaged in overt criminal conduct. Thus, a rational basis exists for legislation that protects the public from insanity acquittees, a special class of persons whose release from detention poses an imminent danger to public safety. ${ }^{257}$

Shortly after the Jones case was decided, a New Jersey appellate court decision, ${ }^{258}$ citing Jones ${ }^{259}$ and a New York Court of Appeals decision upholding post-trial, automatic commitment of insanity acquittees, ${ }^{260}$ distinguished insanity acquittees from other civil committees for escape prosecution. "[I]t is constitutionally permissible," said the New Jersey court, "for the legislature to focus its penal enactment on the danger inherent in an escape by a person with a history of dangerous conduct."261

Because the Jones Court distinguished insanity acquittees from other candidates for civil commitment, other courts are likely to apply their states' general criminal escape statute to insanity acquittees when such statutes are not applied to civil committees. Some states have already enacted statutes specifically criminalizing escape by insanity acquittees but not by regularly civilly committed patients, ${ }^{262}$ and others may do so. Does Jones allow insanity acquittees to be specially identified for escape crime prosecution? Does Jones answer the equal protection challenge?

Although the Supreme Court stated "that insanity acquittees constitute a special class," 263 that statement must be considered in the context of the issues presented in the Jones case. The Jones Court did not consider whether criminal escape statutes can be applied to insanity acquittees when they are not applied to other civilly committed patients. The Jones

criminal sexual psychopaths and persons accused of crime awaiting trial. Id. at 647 .

255. Id. at 647-48.

256. Giles, 662 P.2d at 1077.

257. Id. (citing People v. Chavez, 629 P.2d 1040, 1053 (Colo. 1981))

258. State v. Moore, 471 A.2d 41, 43 (N.J. Super. Ct. App. Div. 1983).

259. Id. (citing Jones v. United States, 463 U.S. 354, 364-65 n.13, 367 (1983)).

260. Id. (citing People ex rel. Henig v. Comm'r of Mental Hygiene, 372 N.E.2d 304, 306 (N.Y. 1977)).

261. Id. Four years earlier, the same court found that the state's predecessor escape statute was "egregiously misapplied" to an insanity acquittee "and that the Legislature did not intend criminal culpability to attach to the wanderings of involuntarily committed persons suffering from mental illness." State v. Kyles, 399 A.2d 1027, 1029 (N.J. Super. Ct. App. Div. 1979). The post-trial confinement of an insanity acquittee was construed to be a civil commitment. See id. at 1029. New Jersey revised its escape statute in response to the Kyles decision. See N.J. StAT. AnN. § 2C:29-5(a) (West 1995).

262. See, e.g., Cal. Penal Code $\S \S 1026,1026.4(a)$ (West Supp. 2003); Fla. Stat. ANN. $\S \S 916.105, .1081$ (West 2001); see supra note 12 and accompanying text.

263. Jones v. United States, 463 U.S. 354, 370 (1983); see supra notes 214-22 and accompanying text. 
Court did not consider whether insanity acquittees are a new classification of mental patient, with characteristics both of mentally ill, sentenceserving convicts and of mentally ill, civilly committed nonconvicts - but not quite either. The issue in Jones was whether the finding of insanity in a criminal trial is sufficiently probative of the acquittee's current mental illness and current dangerousness to justify commitment without the due process protections accorded others undergoing the civil commitment process. ${ }^{264}$ The Court held that the finding of insanity provided a sufficient foundation for commitment without any new hearing on the issues of mental illness and dangerousness. ${ }^{265}$ Thus, insanity acquittees are a special class only in the sense that the insanity finding may itself justify commitment of the acquittee as mentally ill and dangerous, whereas for civil commitment generally, a separate hearing is required to determine whether the potential committee is both mentally ill and dangerous. Although the commitment procedures differ for insanity acquittees, the status of acquittees as civilly committed patients does not. ${ }^{266}$ Because insanity acquittees have not been convicted of crimes, they cannot be punished as criminals. ${ }^{267}$ When they are no longer mentally ill and dangerous, they are entitled to release. ${ }^{268}$

The Jones Court held that proof that the insanity acquittee committed a criminal act satisfies the dangerousness requirement for post-trial

264. Jones, 463 U.S. at 363. Michael Jones did not contest the government's authority to confine mentally ill and dangerous persons indefinitely in mental health facilities. Id. at 362. He merely asserted that the criminal trial at which he was found not guilty by reason of insanity did not constitute an adequate hearing on the issues of current mental illness and current dangerousness to justify such commitment. Id.

265. Id. at 366 .

266. However, at least two, and perhaps as many as four, current Supreme Court Justices construe Jones as dealing with criminal, not civil, commitment of insanity acquittees. See Foucha v. Louisiana, 504 U.S. 71, 94 (1992) (Kennedy, J., dissenting). Chief Justice Rehnquist joined Justice Kennedy in dissenting. Id. at 90. Additionally, Justice Thomas, joined by Justice Scalia and Chief Justice Rehnquist, wrote a separate dissent, distinguishing insanity acquittees from civil committees. See id. at 102, 107-15 (Thomas, J. dissenting). The dissenting justices asserted that a state may reasonably decide to continue the commitment of dangerous insanity acquittees, even if they are not mentally ill. Id. at 111 .

267. See id. at 80 .

268. Id. at 77. In Jones, the Court stated that the insanity acquittee "is entitled to release when he has recovered his sanity or is no longer dangerous." Jones, 463 U.S. at 368. In Foucha, the Court clarified Jones by stating that the insanity acquittee "may be held as long as he is both mentally ill and dangerous, but no longer." Foucha, 504 U.S. at 77 . 
commitment. ${ }^{269}$ However, such proof does not establish that the insanity acquittee is more dangerous than is a person civilly committed as mentally ill and dangerous. Michael Jones, for example, was arrested for attempting to steal a jacket from a department store. He was charged with attempted petit larceny, a misdemeanor punishable by a maximum sentence of one year. ${ }^{270}$ He pleaded insanity, and his plea was not contested. ${ }^{271}$ The Jones majority rejected Jones's assertion that the requisite dangerousness for commitment is not established by proof that he committed a nondangerous property crime. "[V]iolence," said the Court, has never been held to be "a prerequisite for a constitutional commitment." 272 According to the majority, the commission of a criminal act - even an attempted petit larceny-was "at least as persuasive as any predictions about dangerousness that might be made in a civilcommitment proceeding." 273

However, through court decision and legislative enactment, many jurisdictions require far more than a psychiatrist's prediction of future dangerousness to justify civil commitment of a mentally ill person. The commission of a petty larceny or other property crime, ${ }^{274}$ and a prediction that such crime might be repeated, ${ }^{275}$ are simply not enough. To justify civil commitment - a massive curtailment of one's liberty ${ }^{276}$ - many states require proof that the person did some recent

269. Jones, 463 U.S. at 364 . Ironically, when Jones pleaded insanity as a defense to the misdemeanor of attempted petit larceny, the prosecution did not contest the plea, and the facts were stipulated. Without any evidence being submitted to prove that Jones committed a criminal act, the trial court found him not guilty by reason of insanity and committed him to St. Elizabeths Hospital. Id. at 359-60. Uncontested insanity verdicts are not uncommon; they are routine, occurring in many, if not most, cases in which the insanity defense is pleaded. See Michael L. PERlin, The Jurisprudence of THE INSANITY DEFENSE 112-13 (1994) (estimating that eighty to ninety-two percent of insanity defense pleas are uncontested).

270. Jones, 463 U.S. at 359.

271. Id. at 360 .

272. Id. at $364-65$

273. Id. at 364 .

274. See, e.g., Suzuki v. Yuen, 617 F.2d 173, 176 (9th Cir. 1980) (holding unconstitutional a portion of Hawaii's statute that authorized civil commitment of a mentally ill person who is "dangerous to property").

275. Id. at 178 (holding that to justify civil commitment, the danger must be imminent).

276. The Supreme Court has acknowledged that involuntary hospitalization, especially when accompanied by coerced treatment, is "a massive curtailment of liberty." Humphrey v. Cady, 405 U.S. 504, 509 (1972). Those who are involuntarily hospitalized are categorized as "mental patients" and are subjected to psychiatric treatment that probes their innermost thoughts and to psychotropic medication that dulls and alters those thoughts. Heller v. Doe, 509 U.S. 312, 324-25 (1993). Forced administration of psychotropic medication during trial may violate a criminal defendant's constitutional right to a fair trial. Riggins v. Nevada, 504 U.S. 127, 133-38 (1992). Indeed, the Supreme Court has acknowledged that under the Due Process 
overt act, or made an attempt or threat, of physical harm toward himself or another and a prediction that the person will do a similar act in the immediate future unless he is committed. ${ }^{277}$ Some states require even

Clause, even sentence-serving convicts possess "a significant liberty interest in avoiding the unwanted administration of antipsychotic drugs." Washington v. Harper, 494 U.S. 210, 221-22 (1990). "The forcible injection of medication into a nonconsenting person's body represents a substantial interference with that person's liberty." Id. at 229. Involuntarily confined patients may also be subjected to mandatory behavior modification programs. Vitek v. Jones, 445 U.S. 480, 492 (1980). People who are involuntarily hospitalized because they are dangerous are stigmatized by that finding. Addington v. Texas, 441 U.S. 418, 425-26 (1979). Such stigma "can have a very significant impact on the individual." Id. at 426.

277. See, e.g., CAL. Welf. \& InST. CODE $\S 5300$ (West 1998) (requiring that to be subjected to a 180-day renewable civil commitment hold in California, the individual must have attempted, inflicted, or made a serious threat of substantial physical harm upon another person that either resulted in the individual's confinement on a short-term evaluation or treatment hold or that occurred during that hold, and must continue to present a demonstrated danger of inflicting substantial physical harm upon others); MONT. CODE ANN. § 53-21-126 (1)(b)-(c), (2) (2001) (mandating that the court, in determining whether civil commitment is appropriate, shall consider whether the person "has recently, because of a mental disorder and through an act or an omission caused self-injury or injury to others" and "whether, because of a mental disorder, there is an imminent threat of injury to the [person] or to others because of the [person's] acts or omissions" and providing that an "[i]mminent threat of self-inflicted injury or injury to others must be proved by overt acts or omissions, sufficiently recent in time as to be material and relevant as to the [person's] present condition"); NEB. REV. STAT. $\S \S 83-$ 1009, -1037 (1999) (defining mentally ill dangerous person as a mentally ill person who presents a "substantial risk of serious harm to another person or persons within the near future as manifested by evidence of recent violent acts or threats of violence or by placing others in reasonable fear of such harm" or who presents a "substantial risk of serious harm to himself or herself within the near future as manifested by evidence of recent attempts at, or threats of suicide or serious bodily harm," and requiring that the person be found to be a mentally ill dangerous person in order to be subject to civil commitment); 50 PA. STAT. ANN. $\S \S 7301(\mathrm{a}),(\mathrm{b})(1), 7304,7305$ (West 2001) (providing that severely mentally disabled persons are subject to civil commitment and defining a severely mentally disabled person as posing "a clear and present danger of harm to others or to himself," as "shown by establishing that within the past 30 days the person has inflicted or attempted to inflict serious bodily harm on another and that there is a reasonable probability that such conduct will be repeated"); Lessard v. Schmidt, 349 F. Supp. 1078, 1093 (E.D. Wis. 1972) (holding that to justify civil commitment, the state must prove "that there is an extreme likelihood that if the person is not confined he will do immediate harm to himself or others," and this proof of dangerousness must be based "upon a finding of a recent overt act, attempt or threat to do substantial harm to oneself or another").

Although the statutes discussed above establish the criteria for police power based civil commitment of dangerous mentally ill persons, many states also use their parens patriae authority to civilly commit mentally ill persons who are unable to provide for their basic necessities or who lack decisionmaking capacity. See, e.g., CAL. Welf. \& INST. CODE $\S \S 5008$ (h)(1)(A), 5350, 5358(a)(1)-(2) (West 1998) (defining "gravely disabled" as "a condition in which a person, as a result of a mental disorder, is unable to provide for his or her basic personal needs for food, clothing, or shelter," establishing a 
more. To establish that the person presents the requisite substantial probability of physical harm either to that individual or to others, the person must manifest that danger by doing a recent overt act, or by making an attempt or threat, of either suicide or homicide, or some other similar violent act. ${ }^{278}$ Although the Supreme Court has not required violence as a prerequisite for civil commitment, ${ }^{279}$ surely a nonviolent insanity acquittee is less dangerous than a mentally ill person whose attempted homicide or other violent act toward another was a prerequisite to that person's commitment. The fact that the insanity

mental health conservatorship for a gravely disabled person, and authorizing the conservator to subject the conservatee to inpatient commitment); MONT. CODE ANN. $\S$ 53-21-126(1)(a) (2001) (authorizing civil commitment of a person, who, "because of a mental disorder, is substantially unable to provide for [the person's] own basic needs of food, clothing, shelter, health, or safety"); NEB. REV. STAT. § 83-1009(2) (1999) (defining a person as a mentally ill dangerous person, and subject to civil commitment if he or she presents "[a] substantial risk of serious harm to himself or herself within the near future as manifested by ... evidence of inability to provide for his or her basic human needs, including food, clothing, shelter, essential medical care, or personal safety"); 50 PA. STAT. ANN., §§ 7301(a), (b)(2), 7304, 7305 (West 2001). The Pennsylvania statute provides that severely mentally disabled persons are subject to civil commitment and defines a severely mentally disabled person as posing "a clear and present danger of harm to others or to himself." Id. § 7301(a).

Clear and present danger to himself shall be shown by establishing that within the past 30 days ... the person has acted in such manner as to evidence that he would be unable, without care, supervision and the continued assistance of others, to satisfy his need for nourishment, personal or medical care, shelter, or self-protection and safety, and that there is a reasonable probability that death, serious bodily injury or serious physical debilitation would ensue within 30 days unless adequate treatment were afforded under this act.

Id. $\S 7301(\mathrm{~b})$. Parens patriae based civil commitment is beyond the scope of this Article. For a discussion of mental health conservatorships in California, see generally Grant $\mathrm{H}$. Morris, Conservatorship for the "Gravely Disabled": California's Nondeclaration of Nonindependence, 15 SAN DIEGo L. REV. 201 (1978).

278. See, e.g., Wis. STAT. AnN. § 51.20(2)(a)-(b) (West Supp. 2002); Wyo. Stat. ANN. § 25-10-101(a)(ii)(A)-(B) (Michie 2001). The Wisconsin statute requires for civil commitment that the individual "[e]vidences a substantial probability of physical harm to himself or herself as manifested by evidence of recent threats of or attempts at suicide or serious bodily harm" or

[e]vidences a substantial probability of physical harm to other individuals as manifested by evidence of recent homicidal or other violent behavior, or by evidence that others are placed in reasonable fear of violent behavior and serious physical harm to them, as evidenced by a recent overt act, attempt or threat to do serious physical harm.

Wis. STAT. ANN. \& 51.20(2)(a)-(b). The Wyoming statute defines "[d]angerous to himself or others" to mean that the person, as a result of mental illness "[e]vidences a substantial probability of physical harm to himself as manifested by evidence of recent threats of or attempts at suicide or serious bodily harm" or "[e]vidences a substantial probability of physical harm to other individuals as manifested by a recent overt homicidal act, attempt or threat or other violent act, attempt or threat which places others in reasonable fear of serious physical harm to them." WYO. STAT. ANN. § 25-10101(a)(ii)(A)-(B).

279. Jones v. United States, 463 U.S. 354, 365 (1983). 
acquittee's trial established that the acquittee was not criminally responsible for his nonviolent conduct does not justify prosecution for the crime of escape when other escaping patients, who were civilly committed only when they were proven to be even more dangerous, are not. Although not all insanity acquittees are absolved from criminal responsibility for nonviolent crimes, nevertheless, each and every insanity acquittee cannot be presumed to be more dangerous than each and every civilly committed mental patient. Even if we assume that insanity acquittees as a class are more dangerous than other civil committees, that assumption does not establish that any particular person within the class is more dangerous. As the New Jersey Supreme Court so aptly observed: "The decisive consideration where personal liberty is involved is that each individual's fate must be adjudged on the facts of his own case, not on the general characteristics of a 'class' to which he may be assigned." 280

For yet another reason, insanity acquittees should not be distinguished from other mental patients when they escape their confinement. Not only may some insanity acquittees be less dangerous than civil committees, but also some insanity acquittees may be more seriously mentally ill — and thus less criminally culpable for their escape - than are civil committees. After all, the Jones Court ruled that the finding of insanity in the criminal trial warrants an inference, not only of continuing dangerousness, ${ }^{281}$ but of continuing mental illness as well, ${ }^{282}$ constituting an adequate basis to commit the insanity acquittee. The Court rejected Jones's contention that he was entitled to release because he had been hospitalized as an insanity acquittee for a longer period than he could have been incarcerated if he had been convicted of the petit larceny of which he had been charged. ${ }^{283}$ The hypothetical maximum

280. State v. Krol, 344 A.2d 289, 299 (N.J. 1975).

281. Jones, 463 U.S. at 364.

282. Id. at 366 .

283. Id. at 368-69. In his dissenting opinion, Justice Brennan, joined by two other Justices, asserted that the Jones majority posed the wrong question. The issue was not whether Jones was entitled to release because he was hospitalized longer than the hypothetical prison sentence he might have served if he had been convicted. The appropriate issue was whether an insanity acquittal, without more, is a constitutionally adequate basis for indeterminate commitment to a mental health facility. Id. at 371 (Brennan, J., dissenting). Justice Stevens wrote a separate dissent, asserting that at the end of the maximum sentence that could have been imposed if Jones had been found guilty, he was presumptively entitled to his freedom, and if he was to be confined for a longer period, the state was required to prove by clear and convincing evidence that he 
sentence to which Jones could have been sentenced if he had been convicted of the criminal charge did not establish the constitutional limit to his confinement as an insanity acquittee; ${ }^{284}$ in fact, it was irrelevant to the length of that confinement. ${ }^{285}$ Because Jones was not convicted, he could not be punished. He was being confined for treatment, and he could be confined until he recovered his sanity. ${ }^{286}$

If the finding of insanity warrants an inference of continuing mental illness and continuing dangerousness that justifies automatic commitment without any civil commitment hearing to determine the acquittee's current mental condition or current dangerousness, and if that inference is sufficiently strong to permit the acquittee's confinement beyond any hypothetical criminal sentence that could have been imposed if the acquittee had been found guilty, then what, if anything, justifies a nullification of that inference when the insanity acquittee escapes confinement before his sanity has been recovered? The conclusion is inescapable: We really do not believe that insanity acquittees should be absolved from criminal responsibility for their criminal acts. Although the law precludes us from punishing them for their previous crime, we hope to punish them now for their escape. ${ }^{287}$

met the civil commitment criteria. Id. at 387 (Stevens, J., dissenting). As one commentator maintained: "The issue is not how long Jones could be lawfully committed, but rather how long he could be confined under procedures different from those employed for general commitment patients." James W. Ellis, The Consequences of the Insanity Defense: Proposals to Reform Post-Acquittal Commitment Laws, 35 CATH. U. L. REV. 961, 981 (1986). Despite the Jones decision, some states limit the special commitment period for insanity acquittees to the maximum sentence that could have been imposed if the acquittee had been found guilty of the crime. See, e.g., CAL. PENAL CODE $\S 1026.5(a)(1),(b)(1),(b)(8)$ (West Supp. 2003) (codifying, with some modifications, In re Moye, 584 P.2d 1097 (Cal. 1978), and limiting commitment of an insanity acquittee to the maximum term of imprisonment that could have been imposed if the acquittee had been found guilty but establishing a civil commitment procedure to confine for successive two-year periods those acquittees who by reason of mental disorder represent "a substantial danger of physical harm to others").

284. Jones, 463 U.S. at 368.

285. Id. at 369 .

286. Id. The Supreme Court held that it was not unreasonable for Congress to determine that if insanity is successfully used as a defense to a crime, then such "insanity, once established, should be presumed to continue and ... the accused should automatically be confined for treatment until it can be shown that he has recovered." Id. at 364 (quoting S. Rep. No. 84-1170, at 13 (1955)).

287. The Supreme Court of Colorado acknowledged "that an insanity adjudication results in a presumptive continuation of a state of mental incapacity until it is shown that sanity has been restored." People v. Giles, 662 P.2d 1073, 1075 (Colo. 1983). However, the court upheld the conviction of an insanity acquittee for the crime of escape, reasoning that the presumption of insanity is not conclusive and irrebuttable. A finding of insanity for a past crime does not grant immunity for all criminal acts committed by the insane person during his insanity commitment. Id. at 1076. Although the insanity acquittee in this case did not place in issue his mental capacity to commit the crime of escape, if he had done so, the state would have had to prove his sanity beyond a 


\section{Sexually Violent Predators}

In 1990, the state of Washington enacted the nation's first SVP legislation. ${ }^{288}$ Within five years, a handful of states enacted similar, if not virtually identical, legislation. ${ }^{289}$ But unlike the sexual psychopath legislation that it replaced, ${ }^{290}$ SVP statutes did not merely substitute indeterminate confinement for determinate punishment, it added indeterminate confinement upon completion of the offender's criminal sentence.

In 1997, the Supreme Court upheld the constitutionality of Kansas's

reasonable doubt. $I d$. at $1075 \mathrm{n} .4,1076$. It should be noted, however, that many states today place the burden of proving insanity upon the defendant who pleads that defense. Should proof of an insanity acquittal, and an order that the acquittee be committed until sanity has been restored, establish conclusively that the committed acquittee was still insane at the time he escaped?

288. See 1990 Wash. Laws ch. 3 (codified at WASH. REv. CoDE $§ \S 71.09 .010-.902$ (2002 \& Supp. 2003)).

289. See ARIZ. Rev. Stat. AnN. §§ 36-3701 to -3717 (West Supp. 2002) (enacted originally by 1995 Ariz. Sess. Laws ch. 257); CAL. WELF. \& INST. CODE $\S \S 6600-6609.3$ (West 1998 \& Supp. 2003) (enacted originally by 1995 Cal. Stat. ch. 763, § 3); KAN. STAT. ANN. $\S \S 59-29 a 01$ to -29a20 (1994 \& Supp. 2002) (enacted originally by 1994 Kan. Sess. Laws ch. 316); MinN. StAT. ANN. § 253B.185 (West Supp. 2003) (enacted originally by 1994 Minn. Laws, 1st Sp. Sess., ch. 1, art. 1, § 4, which defined "sexually dangerous person" in $\S 253$ B.02(18c)); WIS. STAT. ANN. $\$ \S 980.01-.13$ (West 1998 \& Supp. 2002) (enacted originally by 1993 Wis. Laws 479, § 40). After the United States Supreme Court upheld the constitutionality of SVP legislation in Kansas v. Hendricks, 521 U.S. 346 (1997), several more states enacted SVP legislation. See infra note 318.

290. Forty years ago, more than half the states had enacted sexual psychopath legislation. Weiner, supra note 136, at 739. Through such legislation, criminal defendants charged with or convicted of sex crimes and facing a determinate sentence could be detained indefinitely for treatment until they were no longer dangerous. See id. at 740-41. Sexual psychopath legislation was discredited, however, by the inability of psychiatrists and other mental health professionals to identify a specific mental disorder experienced by individuals who should be included within the targeted group and by the lack of successful treatment methodologies to improve their condition. Id. at 741-43. The absence of treatment destroyed any valid basis for distinguishing sexual psychopath prisoners from other prisoners in order to subject them to indeterminate commitment. Millard v. Cameron, 373 F.2d 468, 473 (D.C. Cir. 1966).

Sexual psychopath legislation was also subjected to procedural due process challenges. For example, in Specht v. Patterson, 386 U.S. 605 (1967), a unanimous Supreme Court ruled that the possibility of indeterminate confinement based on a new finding of fact - that the person constitutes a threat of bodily harm to the public, or is a habitual offender and mentally ill-entitled the person subjected to commitment under Colorado's Sex Offenders Act to the full panoply of due process protections, including the right to counsel, to have an opportunity to be heard, to be confronted with witnesses, to crossexamine, to offer evidence of his own, and to have findings adequate to make a meaningful appeal. Id. at 607-10. 
SVP Act $^{291}$ against three claims of constitutional infirmity. ${ }^{292}$ Under the Kansas statute, a sentence-expiring convict could be civilly committed as an SVP if he had a "mental abnormality" or a "personality disorder" that made him "likely to engage in predatory acts of sexual violence." 293 In Kansas v. Hendricks, ${ }^{294}$ the Court held that the Act satisfied substantive due process requirements. ${ }^{295}$ Justice Thomas, writing for the Court's five-Justice majority, noted that civil commitment statutes have been sustained when they limit the class of persons eligible for confinement to those who, because of mental illness, are dangerous and are unable to control their dangerousness. ${ }^{296}$ Although the Kansas statute used the term "mental abnormality" rather than "mental illness," Justice Thomas dismissed the importance of the distinction, declaring that "the term 'mental illness' is devoid of any talismanic significance."297 The legislature may define terms of a medical nature for legal purposes and need not mirror the definitions of the medical profession. ${ }^{298}$

The majority also found that the Act did not violate the Constitution's prohibition against double jeopardy ${ }^{299}$ or ex post facto lawmaking. ${ }^{300}$ The Court accepted as true the legislature's stated intention to create a new civil commitment scheme for SVPs, rather than to inflict additional punishment for past criminal acts. ${ }^{301}$ Hendricks failed to sustain the heavy

291. Kan. Stat. AnN. §§ 59-29a01 to -29a20 (1994 \& Supp. 2002).

292. Hendricks, 521 U.S. at 371.

293. KAN. STAT. ANN. §§ 59-29a02(a), 59-29a07 (Supp. 2002). As originally enacted, and as interpreted by the Supreme Court in Hendricks, the statute defining SVPs referred to "predatory act of sexual violence." 1994 Kan. Sess. Laws ch. 316, § 2. The statute has been amended and now refers to "repeat acts of sexual violence." KAN. STAT. ANN. § 59-29a02(a).

294. 521 U.S. 346 (1997).

295. Id. at 356-60. The Fourteenth Amendment provides that no state "shall deprive any person of . . . liberty without due process of law." U.S. CONST. amend. XIV.

296. Hendricks, 521 U.S. at 358.

297. Id. at 359. Justice Thomas used, without attribution, language employed by the Supreme Court of Wisconsin two years earlier. In a decision upholding the constitutionality of Wisconsin's SVP statutes, that court stated: "[T]here is no talismanic significance that should be given to the term "mental illness." State v. Post, 541 N.W.2d

115, 122 (Wis. 1995), cert. denied, Post v. Wisconsin, 521 U.S. 1118 (1997).

298. Hendricks, 521 U.S. at 359.

299. Id. at 360-70. The Fifth Amendment, made applicable to the states through the Fourteenth Amendment, provides that no person shall "be subject for the same offense to be twice put in jeopardy of life or limb." U.S. CONST. amend. V.

300. Hendricks, 521 U.S. at 370-71. Article I, Section 9, Clause 3 of the United States Constitution, made applicable to the states through the Fourteenth Amendment, provides that no "ex post facto Law shall be passed." U.S. CONST art. I, § 9, cl. 3.

301. See Hendricks, 521 U.S. at 361. But see State v. Post, 541 N.W.2d at 137 (Abrahamson, J., dissenting). In dissenting from a pre-Hendricks Wisconsin Supreme Court decision upholding the constitutionality of that state's SVP statutes, Justice Abrahamson asserted, "If reference to treatment were sufficient to render a statute civil, however, [Wisconsin's statutes] governing prisons and jails, would be transmogrified into a civil statute." $I d$. 
burden of proving that the legislation was punitive either in purpose or effect. $^{302}$ Incapacitation $^{303}$ - depriving the dangerously mentally ill of their freedom - is a "legitimate nonpunitive governmental objective." "304 Thus, even if SVPs suffer from an untreatable condition, they may be detained so long as they pose a danger to others. ${ }^{305}$ If treatment is possible, the fact that the state provides treatment only incidentally to its primary incapacitation objective does not render the statutes punitive. ${ }^{306}$ Because the Act was found to have a nonpunitive purpose, neither a double jeopardy nor an ex post facto claim could be sustained. ${ }^{307}$ Hendricks was not subjected to multiple punishments because SVP civil commitment is neither punishment that follows a second prosecution for the same crime for which he served a criminal sentence ${ }^{308}$ nor punishment for conduct that was legal before the statutes were enacted. ${ }^{309}$

Justice Breyer wrote a dissenting opinion. Three of the four dissenting Justices agreed with the majority that a state may enact separate civil commitment statutes applicable to different categories of committable individuals. ${ }^{310}$ Hendricks could be civilly committed as an SVP because he suffered from a mental disorder-pedophilia — and

302. Hendricks, 521 U.S. at 361. In finding that the SVP Act was not proven to have a punitive purpose, the majority noted that, unlike a criminal statute, the Act did "not affix culpability for prior criminal conduct" and did not require scienter for commitment. Id. at 362. The Act did not function as a deterrent because those committed as SVPs are unable to exercise control over their behavior and are "unlikely to be deterred by the threat of confinement." Id. at 362-63. Additionally, SVPs experience essentially the same conditions experienced by other civilly committed persons, not the more restrictive conditions experienced by prisoners. Id. at 363 . The Act's use of criminal process-type procedural safeguards to identify those who are civilly committable did not convert the proceedings into criminal proceedings. Id. at 364-65.

303. Id. at 365 .

304. Id. at 363 .

305. Id. at $365-66$.

306. Id. at 366-67.

307. Id. at 369 .

308. Id.

309. Id. at 371. Although Justice Kennedy joined in the Court's majority, he wrote a short concurring opinion expressing his concern about the use of civil commitment laws to confine those who have already been punished through the criminal process. Id. at 371-72 (Kennedy, J., concurring). He cautioned that if civil confinement is used to achieve retribution or general deterrence rather than mere incapacitation, it cannot be validated. Id. at 373 . If "mental abnormality" proves too uncertain a category to justify civil commitment, its use cannot be condoned. Id.

310. Id. at 377 (Breyer, J., dissenting). Justice Ginsberg did not join in this portion of Justice Breyer's opinion and wrote no separate opinion expressing the reasons for her decision. Id. at 373. 
lacked the ability to control his dangerous actions. ${ }^{311}$ Without considering separately whether substantive due process requires the state "to provide treatment that it concedes is potentially available to a person whom it concedes is treatable," 312 the four dissenters focused on the ex post facto claim that posed the same issue. ${ }^{313}$ In their view, the statutes impermissibly imposed punishment by delaying treatment until Hendricks completed his prison sentence. ${ }^{314}$ Under the Act, diagnosis, evaluation, and commitment proceedings - prerequisites for treatment-did not occur until the convict's criminal sentence was about to expire. ${ }^{315}$ Additionally, when commitment proceedings were conducted, the decisionmaker was not required to consider less restrictive alternatives to confinement. ${ }^{316}$ And when Hendricks was civilly committed as an SVP, the record supported the Kansas Supreme Court's finding that the state did not provide treatment. ${ }^{317}$

Although the Court upheld the constitutionality of SVP legislation by the narrowest of margins, many states responded quickly to the Hendricks decision by enacting SVP legislation. ${ }^{318}$ More can be expected to join them. ${ }^{319}$ To avoid constitutional problems, the legislation

311. Id. at $374-77$.

312. Id. at 378 .

313. Id.

314. Id. at 381 .

315. Id. at 385 (citing KAN. STAT. ANN. § 59-29a03(a)(1)).

316. Id. at 387.

317. Id. at 390 (noting that the Kansas Supreme Court found that Hendricks was untreated, not that he was untreatable); see also id. at 392 ("Kansas was not providing treatment to Hendricks."). Under such circumstances, the dissenters agreed with the Kansas Supreme Court's finding that the treatment provisions of the statutes were "somewhat disingenuous." Id. at 393 (citing In re Hendricks, 912 P.2d 129, 136 (Kan. 1966)).

318. See, e.g., Fla. Stat. ANN. §§ 394.910-.931 (West 2002 \& Supp. 2003); 725 ILl. Comp. STAT. $\S$ 207/1-207/99 (2002); IOWA CODE ANN. §§ 229A.1-16 (West 2000 \& Supp. 2002); Mo. ANN. STAT. §§ 632.480-.513 (West $2000 \&$ Supp. 2003); N.J. STAT. ANN. § 30:4-27.24 to .38 (West Supp. 2002); S.C. CODE ANN. §§ 44-48-10 to -170 (Law. Co-op. 2002); Tex. Health \& SAFety CODE ANN. $\S \S 841.001-.147$ (Vernon Supp. 2003); VA. Code ANN. $\S \S 37.1-70.1$ to .19 (Michie Supp. 2002) (effective Jan. 1, 2004). The Illinois statutes were enacted one week after Hendricks was decided. 1997 Ill. Laws 90-40 (approved June 30, 1997, effective Jan. 1, 1998). North Dakota enacted its SVP statutes on April 8, 1997, two months prior to the Hendricks decision, although the statutes became effective more than a month after Hendricks was decided. 1997 N.D. Laws ch. 243, § 1 (approved and filed Apr. 8, 1997, effective Aug. 1, 1997, and codified as N.D. CENT. CODE $§ \S 25-03.3-01$ to -23 (2002)).

319. In Hendricks, thirty-eight states, the District of Columbia, and three territories joined in an amicus brief supporting Kansas's position that SVP legislation is an appropriate and constitutional method to protect citizens from sexually dangerous persons. Brief of Amici Curiae States of Washington et al. at 2, Hendricks (No. 951649). The brief addressed the substantive due process issue. The state of Wisconsin wrote a separate amicus brief addressing ex post facto and double jeopardy issues. Brief of Amicus Curiae State of Wisconsin, Hendricks (Nos. 95-1649 \& 95-9075). The multistate brief expressed its approval of, and expressly adopted, Wisconsin's arguments. 
typically mimics the Kansas model. ${ }^{320}$

Appellate courts have not yet considered whether SVPs can be prosecuted for escape under general escape statutes or whether newly enacted statutes specifically criminalizing escape by SVPs, but not by regularly civilly committed patients, ${ }^{321}$ will survive an equal protection challenge. Commitment under an SVP statute is a civil commitment, and therefore, SVPs are civil mental patients. If other civil mental patients are not subject to prosecution for the crime of escape, arguably, subjecting SVPs to escape prosecution denies them equal protection of the laws. Although SVPs are committed under different criteria than are other civilly committed mental patients, states generally do not criminalize escape by any other civilly committed mental patients,

Brief of Amici Curiae States of Washington et al. at 2, Hendricks (No. 95-1649).

320. For example, many of the statutes begin with a statement of legislative findings borrowed, nearly verbatim, from the Kansas statute, as it was originally enacted, 1994 Kan. Sess. Laws ch. 316, § 1, or from the Washington statute from which the Kansas statute was derived:

The legislature finds that a small but extremely dangerous group of sexually violent predators exist who do not have a mental disease or defect that renders them appropriate for [the existing involuntary civil commitment law], which is intended to be a short-term civil commitment system that is primarily designed to provide short-term treatment to individuals with serious mental disorders and then return them to the community. In contrast to persons appropriate for civil commitment...., sexually violent predators generally have personality disorders and/or mental abnormalities which are unamenable to existing mental illness treatment modalities and those conditions render them likely to engage in sexually violent behavior. The legislature further finds that [SVPs'] likelihood of engaging in repeat acts of predatory sexual violence is high. The existing involuntary commitment [laws are] inadequate to address the risk [of reoffense].... The legislature further finds that the prognosis for curing [SVPs] is poor, the treatment needs of this population are very long term, and the treatment modalities for this population are very different than the traditional treatment modalities for people appropriate for commitment under [the existing involuntary civil commitment law].

Wash Rev. Code AnN. § 71.09.010 (West 2002); see also KAn. Stat. AnN. § 59-29a01 (Supp. 2002). States that begin their SVP Acts with a similar statement of legislative findings include: ARIZ. REV. STAT. ANN. § 36-3701 (West Supp. 2002) (quoting 1995 Ariz. Sess. Laws ch. 257, $\S 10$, which includes the legislature's findings within the notes to the statute); CAL. WELF. \& INST. CODE $§ 6600$ (West 1998 \& Supp. 2003) (quoting 1995 Cal. Stat. ch. 763, $\S 3$, which includes the legislature's findings within the historical notes to the statute); FlA. STAT. ANN. § 394.910 (West 2002); IOWA CODE $§$ 229A.1 (West 2000); N.J. STAT. ANN. § 30:4-27.25 (West Supp. 2002); S.C. CODE ANN. § 44-48-20 (Law. Co-op. 2002); and TeX. Health \& SAFETy CODE ANN. § 841.001 (Vernon Supp. 2003).

321. See, e.g., Fla. Stat. Ann. § 394.927(1) (West 2002); Iowa Code AnN. § 229A.5B(1)-(2) (West Supp. 2002); VA. CODE ANN. § 37.1-70.18 (Michie Supp. 2002) (effective Jan. 1, 2004); WASH. Rev. CODE ANN. § 9A.76.115 (West Supp. 2003). 
regardless of differences in the criteria for their commitment. Prosecution for escape does not occur whether the patients have been committed through the state's police power as dangerously mentally ill or whether they have been committed through the state's parens patriae authority as unable to provide for basic necessities or lacking in decisionmaking capacity. ${ }^{322}$ To prosecute SVPs for the crime of escape impermissibly distinguishes them from all other civilly committed patients.

In an analogous context, the Supreme Court of Washington has repeatedly held that the equal protection clauses of the federal and state constitutions require that less restrictive alternatives to confinement must be considered at SVP commitment trials, just as such alternatives are required to be considered for patients undergoing commitment through the regular civil commitment statutes. ${ }^{323}$ Because not all SVPs present the same level of danger or require identical treatment conditions, no rational basis exists for refusing to consider alternatives to confinement of SVPs while according such consideration to all other patients. ${ }^{324}$ One could assert that if SVPs are similarly situated with other civil mental patients for consideration of less restrictive alternatives to confinement, they are similarly situated with other civil mental patients for other purposes, including exemption from criminal prosecution when they escape.

But such an assertion would not go uncontested. Even prior to the Supreme Court's Hendricks decision, the supreme courts of Wisconsin ${ }^{325}$ and Minnesota ${ }^{326}$ rejected equal protection attacks premised on differences in substantive standards and procedures for SVP commitment than for other civil commitment. "The state's compelling interest in protecting the public," said the Supreme Court of Wisconsin, "provides the necessary justification for the differential treatment of the class of sexually violent persons whose mental disorders make them distinctively dangerous because of the substantial probability that they

322. See supra note 277 (citing statutes providing for police power and parens patriae civil commitment).

323. In re Brooks, 36 P.3d 1034, 1037 (Wash. 2001); In re Young, 857 P.2d 989, 1012 (Wash. 1993).

324. Young, 857 P.2d at 1012. In 1995, the Washington Legislature, responding to the Washington Supreme Court's decision in Young, amended the SVP statute to permit a consideration of less restrictive alternatives to confinement for SVPs only after the commitment trial that determines whether the person is an SVP. Brooks, 36 P.3d at 1039. Nevertheless, in 2001, the Washington Supreme Court found no reason to depart from its position in Young, holding that SVPs are similarly situated with other civilly committed mental patients for the purpose of considering less restrictive alternatives to confinement at the time of the commitment decision. Id. at 1042.

325. State v. Post, 541 N.W.2d 115, 130-32 (Wis. 1995), cert. denied sub nom. Post v. Wisconsin, 521 U.S. 1118 (1997).

326. In re Linehan, 557 N.W.2d 171, 186-87 (Minn. 1996), vacated and remanded for reconsideration in light of Hendricks sub nom., Linehan v. Minnesota, 522 U.S. 1011 (1997). 
will commit future crimes of sexual violence." 327 The legislature may "address complex social problems in more than one way" 328 and may create and implement "a variety of solutions aimed at controlling a variety of ills." ${ }^{29}$ The legislature may determine that, because of their predisposition to sexual violence, SVPs as a class pose a higher danger to the community than do other mentally ill persons. This heightened danger and the unique treatment needs of SVPs justify a distinct legislative approach to protect the public. ${ }^{330}$ The equal protection argument, said the Minnesota Supreme Court, "ignores the fact that the sexual predator poses a danger that is unlike any other." 331

After the Hendricks Court placed its imprimatur upon SVP legislation, several state supreme courts rejected equal protection challenges to their states' SVP legislation. ${ }^{332}$ The Florida Supreme Court, for example, held that a legislative decision precluding consideration of less restrictive alternatives to SVP confinement does not violate equal protection of the laws despite the legislative policy requiring utilization of least restrictive appropriate treatment for regularly civilly committed patients. $^{333}$ SVPs, said the court, are not similarly situated with other

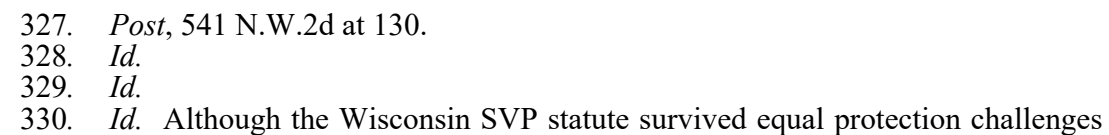
to differences in both the substantive standards and procedures for commitment, the court upheld the right of SVPs to jury trials at discharge hearings as is provided to other civilly committed mental patients. Id. at 132-33.

331. In re Blodgett, 510 N.W.2d 910, 917 (Minn. 1994) (upholding the Minnesota Psychopathic Personality Commitment Act against a claim that it violated equal protection). In Linehan, the Minnesota Supreme Court stated that "Blodgett controls our analysis." 557 N.W.2d at 186 (stating that deference to legislative judgment is due because the legislature "permissibly drew genuine and substantial distinctions that define a class of dangerous and mentally disordered persons who victimize others in a particular manner").

332. See, e.g., Hubbart v. Superior Court, 969 P.2d 584, 604-05 (Cal. 1999) (holding that the required finding of present dangerousness for SVP commitment is not "materially distinct" from the dangerousness criterion used in other commitment statutes, and therefore, SVPs are not subjected to disparate treatment); In re Samuelson, 727 N.E.2d 228, 236-37 (Ill. 2000) (holding that, without offending equal protection, the legislature may accord different rights to defendants in criminal cases and to persons undergoing regular civil commitment than to persons undergoing civil commitment as SVPs); In re Campbell, 986 P.2d 771, 777 (Wash. 1999) (holding that SVPs are not similarly situated with other mentally disordered persons undergoing traditional civil commitment and that differences in the statutes as to who qualifies as an expert to sign a commitment petition are rationally related to the differences between the two groups).

333. Westerheide v. State, 831 So. 2d 93, 111-12 (Fla. 2002). 
civilly committed mental patients. ${ }^{334}$ The legislature distinguished SVPs as having "antisocial personality features which are unamenable to existing mental illness treatment modalities" that "render them likely to engage in criminal, sexually violent behavior." "335 Their "treatment needs ... are very long term' and necessitate very different treatment modalities from those appropriate for [other civilly committed mental patients]." ${ }^{336}$ By legislative definition:

only those individuals who require long-term treatment in a secure facility qualify for commitment under [Florida's SVP statutes] and no less restrictive alternative is appropriate for these individuals. In contrast, involuntary commitment under [Florida's regular civil commitment statutes] is intended to provide "intensive short-term ... treatment" to persons with serious mental disorders and return them "to the community as soon as possible." 337

In Hendricks, the Supreme Court did not consider whether special civil commitment legislation for SVPs violates the Equal Protection Clause. The Court did not consider whether prosecution of SVPs for the crime of escape when other civilly committed mental patients are not prosecuted violates the Equal Protection Clause. In fact, the words "equal protection" do not appear even once in Justice Thomas's majority opinion, in Justice Kennedy's concurring opinion, or in Justice Breyer's dissenting opinion. ${ }^{338}$ But given the Court's rejection of Hendricks's

334. Id. at 112 .

335. Id. (quoting FLA. STAT. § 394.910); see supra note 320.

336. Westerheide, 831 So. 2 d at 112 (quoting FLA. STAT. § 394.910).

337. Id. (quoting Fla. STAT. § 394.453).

338. Leroy Hendricks did raise an equal protection claim in his cross-petition to the Supreme Court. Conditional Cross Petition at 17, Kansas v. Hendricks, 521 U.S. 346 (1997) (No. 95-9075). However, his brief as cross-petitioner did not argue the equal protection claim. In a footnote, the cross-petitioner stated: "Mr. Hendricks' crosspetition also sought review of his equal protection challenge to the statute. This claim will be subsumed in his substantive due process argument, and will not be separately briefed." Brief for Leroy Hendricks Cross-Petitioner, Hendricks (Nos. 95-1649, 959075), available at 1996 WL 450661 , at $* 2$ n.1. In the brief submitted by Kansas as cross-respondent, Kansas asserted that Hendricks abandoned his equal protection claim by failing to argue its merits in his cross-petitioner's brief and requested that the Court so rule. Brief of Cross-Respondent, Hendricks (No. 95-9075), available at $1996 \mathrm{WL}$ 509502 , at $* 4, * 39-40$. The state characterized this failure as an apparent attempt to evade the page limit requirements established by Supreme Court rule "or to manipulate the briefing process" by forcing the state either to address first the equal protection claim that Hendricks alone had raised or to wait until the state's final reply brief to respond. $I d$. at $* 40$. In his reply brief as cross-petitioner, Hendricks did not address the state's argument. See Reply Brief for Cross Petitioner, Hendricks (Nos. 95-1649, 95-9075), available at 1996 WL 593579.

The Supreme Court did not discuss the question of whether Hendricks's equal protection claim could be appropriately subsumed within his substantive due process argument or comment on the state's request for a ruling that Hendricks had abandoned his equal protection claim. The Court merely noted that Hendricks's cross-petition asserted double jeopardy and ex post facto claims. Hendricks, 521 U.S. at 350 (1997). 
substantive due process argument, it is unlikely that the Court would have accepted an equal protection argument that equated SVPs with other civilly committed mental patients. ${ }^{339}$ The Hendricks majority found that the legislature may identify for civil commitment purposes "a limited subclass of dangerous persons." 340 The Kansas SVP Act met that requirement by restricting SVP commitment to individuals who have a mental abnormality or personality disorder rendering them unable to control their dangerousness. ${ }^{341}$ Even three of the four dissenting Justices agreed that Kansas is not constitutionally prohibited from adopting two separate civil commitment statutes "each covering somewhat different classes of committable individuals." "342 Thus, while Washington and other states may choose to consider less restrictive alternatives to confinement for SVPs who are not so dangerous that they need to be confined, ${ }^{343}$ for those dangerous SVPs who must be confined, an equal protection argument that they are no more dangerous than other civilly committed mental patients is likely to fail.

Post-Hendricks Supreme Court decisions also suggest that the Court will not be receptive to an equal protection claim that escape by SVPs cannot be criminalized because SVPs are similarly situated with other civilly committed mental patients who are not subject to such prosecution. The Court has both contracted the rights of SVPs and expanded the group of persons who can be identified as SVPs. In 2001, the Supreme Court ruled that if a state court finds that the legislature had a legitimate, nonpunitive purpose for enacting SVP legislation-and incapacitation of mentally abnormal persons to protect society from sexually violent acts associated with that abnormality is such a purpose - then an SVP may not claim that the legislation, as implemented and applied to him, was punitive. ${ }^{344}$ Even though the Special Commitment Center, which housed all of Washington's SVPs, was located within the perimeter of a Department of Corrections facility,

339. See Grant H. Morris, The Evil that Men Do: Perverting Justice to Punish Perverts, 2000 U. ILL. L. REV. 1199, 1213-17 (asserting that an equal protection argument that SVPs are similarly situated with other civilly committed patients will not succeed).

340. Hendricks, 521 U.S. at 357.

341. Id. at 358 .

342. Id. at 377 (Breyer, J., dissenting).

343. See supra notes 323-24 and accompanying text.

344. Seling v. Young, 531 U.S. 250, 263 (2001). The Court held: "An Act, found to be civil, cannot be deemed punitive 'as applied' to a single individual in violation of the Double Jeopardy and Ex Post Facto Clauses and provide cause for release." Id. at 267. 
conditions at the Center were incompatible with statute's stated goal of treatment, and there was no possibility of release, ${ }^{345}$ the Supreme Court refused to consider the possibility that the legislature's intent was to punish SVPs by confining them for life-without treatment and without hope. ${ }^{346}$

In 2002, the Supreme Court broadened the permissible definition of SVPs, holding that in SVP commitment proceedings, the state is not required to prove that the person is completely unable to control his dangerous behavior. ${ }^{347} \mathrm{He}$ can be labeled an SVP so long as a mental abnormality makes it difficult for him to do so. ${ }^{348}$

In upholding the Kansas SVP Act against due process, double jeopardy, and ex post facto claims, the Hendricks Court found "that the Kansas Legislature [had] taken great care to confine only a narrow class of particularly dangerous individuals." ${ }^{349}$ SVPs, who by definition are likely to engage in predatory ${ }^{350}$ acts of sexual violence and who, because of mental disorder, are unable to control or have great difficulty in controlling $^{351}$ their behavior are more dangerous as a group than are other civilly committed mental patients. An equal protection claim that asserts that SVPs are similarly situated with other mental patients for civil commitment purposes or for criminal prosecution for escape is likely to fail.

Nevertheless, because SVP legislation is applicable to only some persons who can be categorized as SVPs, such legislation may be

345. Id. at 259-60.

346. See id. at 263 ("The civil nature of a confinement scheme cannot be altered based merely on vagaries in the implementation of the authorizing statute.").

347. Kansas v. Crane, 534 U.S. 407, 411 (2002).

348. Id. at 411-14. State courts have also broadened the SVP definition. For example, in 2002, the California Supreme Court ruled that the SVP statute's definitional requirement that the person be "likely to engage in acts of sexual violence without appropriate treatment and custody", does not mean that the risk of such conduct be greater than fifty percent. People v. Superior Court (Ghilotti), 44 P.3d 949, 954, 968 (Cal. 2002) (quoting CAL. WELF. \& INST. CODE $\S$ 6601(d) (emphasis added)). The "likely" standard is met if the person "presents a substantial danger-that is, a serious and well-founded risk - of criminal sexual violence." Id. at 954. Even though, as a concurring justice pointed out, the word "likely" in ordinary and legal usage means "having a better chance of occurring than not," and that virtually all violent offenders with a sexual disorder would qualify for SVP commitment under the majority's "substantial danger" standard, id. at 977-79 (Werdegar, J., concurring), the majority, nevertheless adopted the expanded definition, $i d$. at 968.

349. Kansas v. Hendricks, 521 U.S. 346, 364 (1997). In summarizing the reasons for the Court's decision, Justice Thomas characterized the Act as limiting "confinement to a small segment of particularly dangerous individuals." Id. at 368.

350. Since the decision in Hendricks, the Kansas legislature has amended the statute to require a likelihood of "repeat" acts of sexual violence instead of "predatory" acts of sexual violence. See supra note 293.

351. Crane, 534 U.S. at 411-14 (holding that "difficulty" in controlling sexually violent behavior, not complete or total lack of control, is sufficient to qualify a person as an SVP); see supra notes 347-48 and accompanying text. 
vulnerable to a different equal protection attack. ${ }^{352}$ The Kansas SVP Act, just as most states' SVP legislation, does not authorize civil commitment of all those who suffer from a mental disorder, no matter how narrowly or broadly defined, and who are likely to engage in predatory acts of sexual violence. Rather, SVP commitment is limited only to persons who fit within one of three groups who are about to be released from confinement: sentence-expiring convicts, persons found mentally incompetent to stand trial, and insanity acquittees. ${ }^{353}$

Individuals who do not fit into one of these three categories are not subject to SVP commitment even if they are equally likely to engage in sexually violent conduct and are unable to control their dangerousness due to mental abnormality or personality disorder. Thus, for example, ex-convicts who were punished for sexually violent crimes and who could be predicted to commit additional sexually violent crimes are not subject to SVP commitment if they already served their criminal sentences and were released from confinement before the SVP Act was enacted. Criminal defendants charged with, but not yet convicted of, sexually violent offenses and who could be predicted to commit additional sexually violent crimes are not subject to SVP commitment. Criminal defendants who have been charged with violent crimes, but not sexually violent crimes, are not subject to SVP commitment. Individuals who have not yet been charged with sexually violent crimes, and indeed, individuals who have not yet committed such crimes are not subject to SVP commitment. And yet, in each case, their mental abnormalities or personality disorders and their difficulty in controlling their sexual urges may make them equally dangerous with those who are about to be released from confinement and who have been legislatively targeted for special SVP commitment. ${ }^{354}$ Although the Supreme Court

352. See Morris, supra note 339, at 1217-27 (asserting that a successful equal protection argument may be made that sentence-expiring convicts and others who may be identified as SVPs and subjected to SVP commitment are similarly situated with other persons identifiable as SVPs but not subject to SVP commitment).

353. See KAN. StAT. ANN. §§ 59-29a03, 59-29a04 (Supp. 2000).

354. Consider, for example, the case of In re Diestelhorst, 716 N.E.2d 823 (Ill. App. Ct. 1999). A pedophile, released after serving a ten-year prison term for sexually molesting children, attempted to lure a young girl into his car. He was apprehended and pled guilty to the crime of child abduction. Id. at 824 . As his sentence was expiring, the state petitioned for SVP commitment. Id. at 825. Despite expert testimony that the prisoner had a "lingering sexual penchant for children," $i d$., the appellate court dismissed the petition, $i d$. at 829 . Child abduction is not a sexually violent offense, and under Illinois law, only those who are completing confinement for a sexually violent offense 
permits the legislature "to recognize degrees of harm, and it may confine its restrictions to those classes of cases where the need is deemed to be clearest," ${ }^{355}$ the Equal Protection Clause prohibits the legislature from discriminating between individuals when the they pose an equal danger. The state has no compelling interest to so discriminate.

Baxstrom v. Herold ${ }^{356}$ and Jackson v. Indiana ${ }^{357}$ tell us that sentenceexpiring convicts and permanently incompetent criminal defendants cannot be specially classified for civil commitment purposes. SVP legislation, however, separately categorizes these individuals for SVP commitment. Baxstrom and Jackson tell us that the same civil commitment standards and procedures must be applied to sentence-expiring convicts and permanently incompetent defendants that are applied to any other nonconvicts. SVP legislation, however, applies different commitment standards and procedures to these individuals for SVP commitment. If sentence-expiring convicts and permanently incompetent defendants can only be involuntarily confined as are other civilly committed patients, then they are civilly committed patients, and cannot be morphed into SVPs or another special hybrid class of patient with "criminal" as well as "civil" features.

Although Jones $v$. United States ${ }^{358}$ tells us that insanity acquittees can be specially classified for post-criminal trial confinement without undergoing the civil commitment process, their special classification for SVP commitment purposes cannot be justified. Insanity acquittees are not subject to SVP commitment immediately after their criminal trials, but rather only after they are about to be released from confinement as insanity acquittees. ${ }^{359}$ Such release does not occur until the acquittee is no longer dangerous, that is, is not likely to cause harm either to the acquittee or others. ${ }^{360}$ Thus, an insanity acquittee who currently "suffers

are subject to SVP commitment. Id. at 827 . The court rejected the state's argument that SVP commitment is appropriate because the crime, although not specifically defined as violent, was sexually motivated. Id. at 827-29. The perpetrator, according to the state, sought to gratify "an aberrant sexual preference. He wanted to sexually molest his prey." $I d$. at 826 . If, as the court assumed, the state correctly assessed the criminal's motivation, would anyone believe that this individual is less sexually dangerous than another pedophile who was not apprehended until after he sexually molested a child and who was therefore subject to SVP commitment?

355. Minnesota ex rel. Pearson v. Probate Court, 309 U.S. 270, 275 (1940).

356. 383 U.S. 107 (1966); see supra notes 99-110 and accompanying text.

357. 406 U.S. 715 (1972); see supra notes 162-69 and accompanying text.

358. 463 U.S. 354 (1983); see supra notes 214-22 and accompanying text.

359. See, e.g., KAN. STAT. ANN. §§ 59-29a03, 59-29a04 (Supp. 2000).

360. Id. $\S \S 22-3428(3)$ (authorizing transfer to a less restrictive hospital environment, conditional release, or discharge), 22-3428(7) (defining "mentally ill person" as one who "is likely to cause harm to self or others," that is, one who "is likely, in the reasonably foreseeable future, to cause substantial physical injury or physical abuse to self or others or substantial damage to another's property, or evidenced by behavior causing, 
from a mental abnormality or personality disorder which makes [him] likely to engage in repeat acts of sexual violence"-the definitional criteria for SVP adjudication ${ }^{361}$ — is unlikely to be released from insanity acquittee commitment as not dangerous. In reality, insanity acquittees who are not too dangerous to be released from insanity acquittee confinement but who are dangerous enough to be confined as SVPs do not exist. Insanity acquittees, therefore, are not a special category for SVP commitment purposes; they are a noncategory.

\section{Conclusion: Protecting the Public Without PUNISHING THE UNPUNISHABLE}

Laws that criminalize escape by involuntarily confined mental patients attempt to enhance public security by discouraging escape from mental health facilities. Typically, those laws do not specifically apply to civilly committed mental patients and are not construed by courts to apply to them. In essence, criminalization of escape by "regular" mental patients is rejected as a poor, or unneeded, public policy decision. Society is reluctant to punish mentally ill people, especially those who are so severely mentally ill that they must be involuntarily hospitalized. However, legislatures and courts are more willing to criminalize escape by "special" civilly committed patients, such as sentence-expiring convicts, incompetent criminal defendants, insanity acquittees, and SVPs. This Article asserts that criminalizing escape by some or all of these specially categorized patients violates equal protection of the laws. But if we cannot deter their escape by criminalizing such conduct, can we facilitate the public's legitimate interest in security through other measures?

\section{A. Enhancing Security}

First, security measures should be employed for every mental patient, whether regularly or specially committed, that are appropriate to the risk of escape and the danger presented if escape occurs. As Henry Weihofen noted more than forty years ago: "What security measures are needed depends on the diagnosis of the individual patient's mental condition-not on the type of crime that he has committed or with which he is

attempting, or threatening such injury, abuse or neglect"). In many states, insanity acquittees may not be released until a court finds that they are no longer dangerous to others. See, e.g., CAL. Penal CodE $§ 1026.2$ (West Supp. 2003).

361. KAN. Stat. ANN. § 59-29a02(a) (Supp. 2000). 
charged." 362 After Ronald Rogers escaped from Atascadero State Hospital, a ten-foot tall fence with double rows of razor wire at the top and a single row along the bottom was installed on the single-story roof of the Administration Building from which he escaped. ${ }^{363}$ A double fence now completely encircles the facility. A security alarm is being installed that will sound if contact is made with the fence. Internal courtyards are surrounded by razor wire topped walls on two-story buildings or by sixteen-foot tall fencing where no walls exist. ${ }^{364}$ Other security measures include guards in observation towers and patrolling hospital grounds twenty-four hours a day, seven days a week ${ }^{365}$ and a personal count of each patient conducted six times within each twenty-four hour period. ${ }^{366}$

Security measures can minimize, if not eliminate, patient escapes. No patient has escaped from Atascadero since new security measures were implemented. Even before security was heightened, escape from Atascadero was rare. In the ten years prior to Ronald Rogers's escape, only two patients escaped, and one of those was apprehended within twenty minutes. ${ }^{367}$ There is no record of any crime being committed by an escapee, including the one patient who escaped over nine years ago and who has not been apprehended. ${ }^{368}$ Atascadero's escape record is not unique. Years ago, a New York Supreme Court justice noted that when

362. Henry Weihofen, Institutional Treatment of Persons Acquitted by Reason of Insanity, 38 TEX. L. REV. 849, 856 (1960); see also supra notes 65-67 and accompanying text (asserting that even security measures for a convict mental patient depend upon the pathology and severity of the patient's illness, not upon his status as a prisoner).

363. E-mail from Barrie Hafler, Public Relations Officer, Atascadero State Hospital, to Grant Morris, Professor of Law, University of San Diego School of Law (Jan. 3, 2003, 12:37:43 PST) (on file with author).

364. Id. See generally L.W. Allan, State Hospital: Recent Upgrades Intended to Make It Even More Secure, ATASCADERO News, May 1, 2002, at A-1; Rachel Robertshaw, Sexually Violent Predator Escapes ASH, AtASCADERo News, Sept. 26, 2001, at A-1.

365. Allan, supra note 364

366. Robertshaw, supra note 364. On the day that Ronald Rogers escaped, staff observed what appeared to be Rogers asleep in his room. However, the staff failed to follow the hospital's policy of verifying Rogers's presence by making visual contact with him. Id.; see supra note 2.

367. E-mail from Barrie Hafler, Public Relations Officer, Atascadero State Hospital, to Grant Morris, Professor of Law, University of San Diego School of Law (Nov. 20, 2002, 10:42:09 PST) (on file with author). Cleopus Johnson, a mentally ill prisoner, escaped on August 15, 1993 and is still missing. James Howe, who was awaiting trial to determine whether he was committable as an SVP, escaped on February 2, 1999 and was apprehended within twenty minutes. Ronald Rogers, an SVP, escaped on September 23, 2001 and was apprehended in Oregon on October 1, 2001. A fourth patient, Duane Harris, committed as incompetent to stand trial, bolted from custody while he was at a medical diagnostic appointment in the community. After fifteen minutes of chase, he was brought into custody. This incident was not recorded as an escape from the hospital. Id.

368. Id. 
patients were sent to the two maximum security mental hospitals in that state, "nobody escaped." 369

\section{B. Providing Treatment Opportunities}

Maximum security is not appropriate for each and every involuntarily confined mental patient. And whatever security measures are appropriate to prevent escape should not detract from treatment opportunities available to patients within the facility. In fact, actively engaging patients in treatment enhances, not detracts, from security. Patients who believe they will be discharged to the community if treatment of their mental condition is successful are less likely to attempt escape to secure their freedom than those who believe that treatment is a sham, or is nonexistent, or that they are being held indefinitely for punishment. ${ }^{370}$

The problem is particularly acute for patients classified as SVPs. Almost all of these patients completed a criminal sentence and expected to be released from confinement. Instead, they were civilly committed - typically to a maximum security unit or facility - for an indeterminate period of time. In many states, the legislature declared SVPs to be an "extremely dangerous group" who "have personality disorders and/or mental abnormalities which are unamenable to existing mental illness treatment modalities," that their "prognosis for cur[e] ... is poor," and that their "treatment needs ... are very long term." 371 SVPs do not believe that they will be released even if they participate in treatment programs available to them and even if their treatment is successful. ${ }^{372}$ And they may be right.

369. People v. Ortega, 487 N.Y.S.2d 939, 947 (Sup. Ct. 1985) (referring to Matteawan and Dannemora State Hospitals), aff'd, 499 N.Y.S.2d 1018 (App. Div. 1986), appeal granted, 497 N.E.2d 717 (N.Y. 1988), aff'd, 505 N.E.2d 613 (N.Y. 1987). Both Matteawan and Dannemora State Hospitals were maximum security mental hospitals.

370. However, the promise of hospital discharge if treatment is successful is not a panacea for all classes of patients. For example, a sentence-serving prisoner who faces return to prison and not community placement if hospital treatment is successful may not be motivated to cooperate with treatment. Similarly, a mentally incompetent criminal defendant who faces return to court for trial and potential imprisonment thereafter if hospital treatment is successful may not be motivated to cooperate with treatment. In these cases, the patient may attempt escape to avoid post-hospital confinement that is viewed as less desirable.

371. See, e.g., WASH. REV. CODE ANN. § 71.09.010 (West 2002); see supra note 320.

372. SVP program staff are reluctant "to predict nonrecidivism, given the general difficulties of making predictions in this area, as well as the high costs to the clinical 
Atascadero State Hospital, for example, has developed a five-phase, state-of-the-art, cognitive-behavioral therapy program for SVPs. ${ }^{373}$ Upon admission to Atascadero, SVPs are placed in phase one. If they are willing to participate in treatment, they move through the various phases, acquiring and practicing skills, such as anger management, stress reduction, and coping with high-risk situations, to prepare them for a return to society. In phase five, they are placed outside the institution in a supervised, conditional release outpatient program. ${ }^{374}$ Of the 471 SVPs placed in Atascadero since the law was enacted in 1996, 392 $(83.2 \%)$ remain in phase one. Only sixty-six SVPs $(14.0 \%)$ are in phase two, eleven $(2.3 \%)$ are in phase three, two $(.004 \%)$ are in phase four, and none are in, or have ever been placed in, phase five. ${ }^{375}$ One patient completed phase four and could have been released into a conditional release program, but he rejected, as too onerous, the conditions placed upon him for release, and he remains confined in Atascadero. ${ }^{376}$

evaluator of false-negative predictions and the low cost of making false-positive ones." Bruce J. Winick, Sex Offender Law in the 1990s: A Therapeutic Jurisprudence Analysis, 4 PSYCHOL. PuB. POL'Y \& L. 505, 544 (1998).

373. An American Psychiatric Association Task Force reported that treatment of paraphilic behavior today "generally includes cognitive-behavior treatment with a strong focus on relapse prevention and the use of medications to reduce sexual drive, including medroxyprogesterone acetate, and, more recently, serotonin reuptake inhibitors." AM. PSychiatric Ass'N, Dangerous SeX OfFenders 75 (1999). The Task Force found "that cognitive-behavior and relapse prevention techniques are more successful and more accepted treatments than psychodynamic treatment, although treatment efficacy is controversial for every approach." Id. at 170-71. Behavior therapies enable persons with paraphilia to gain control over paraphilic behavior by blocking or reducing the person's thoughts of, fantasies about, and urges toward deviant objects or behavior. Id. at 62. Pharmacological treatment with antiandrogens and hormonal agents reduces recidivism by persons with paraphilia by reducing sexual fantasies, sexual arousal, and sexual behavior. Id. at 118 .

Sentence-serving convicts have an incentive to participate and succeed in mental treatment programs if a positive treatment outcome increases the possibility of the prisoner's release on parole. Nevertheless, sex offenders typically receive no treatment for their mental conditions when they are serving their penal sentences. See Winick, supra note 372, at 540-44. Delaying treatment for sexual predators until they serve their penal sentences and are committed as SVPs has been characterized as a "blatantly antitherapeutic approach." Id. at 542. The American Psychiatric Association Task Force specifically recommends that convicted sex offenders have the opportunity to participate voluntarily in cognitive-behavior treatment programs while they are serving their criminal sentences. AM. PsyCHIATRIC Ass'N, supra at 162, 177.

374. Patrick S. Pemberton \& Maria T. Garcia, Inside Atascadero State Hospital: Debt to Society vs. Threat to Society, Tribune (San Luis Obispo County, Cal.), Nov. 18, 2001, at A1. The phases include treatment readiness, skill acquisition, skill application, and discharge preparation. Id.

375. Statistical information dated Oct. 2, 2002, distributed to members of the Atascadero State Hospital Advisory Board, Dec. 12, 2002 (on file with author). The total SVP population was erroneously reported as 452 patients, although the number of SVP patients in all treatment phases actually totaled 471 .

376. The patient, Patrick Ghilotti, initially agreed to the conditions for release, 
Although the Hendricks Court held that incapacitation of untreatable SVPs may itself be a legitimate end of the civil law, ${ }^{377}$ the Court noted that Kansas's ancillary goal was to provide treatment to SVPs if such treatment was possible. ${ }^{378}$ By furnishing treatment to those who are treatable, the state establishes that its purpose is not to punish. ${ }^{379}$

Despite increasing evidence that cognitive-behavioral treatment programs are effective and do significantly reduce recidivism by sex offenders, ${ }^{380}$ many people believe that SVPs are untreatable. SVPs are typically diagnosed with a paraphilia, ${ }^{381}$ a mental disorder involving recurrent sexual urges and behavior involving children or other

including taking Lupron, a testosterone-reducing drug that produces unpleasant and medically adverse side effects, wearing a global positioning system device so that his movements could be monitored, and participating in group therapy sessions. However, he ultimately refused to accept additional conditions that restricted visits with his wife and use of the Internet. Kim Curtis, Serial Rapist at ASH May Go Free, TribunE (San Luis Obispo County, Cal.), Nov. 30, 2001, at A1. The district attorney petitioned to recommit Ghilotti as an SVP to a two-year term of hospital confinement and treatment. People v. Superior Court (Ghilotti), 44 P.3d 949, 954 (Cal. 2002). Although two psychologist evaluators determined that Ghilotti no longer met the statutory criteria for SVP commitment, id. at 955, the California Supreme Court ruled that the evaluators' recommendations against recommitment were invalid if they were influenced by the evaluators' legal error in misinterpreting the "likely to reoffend" standard, id. at 954, 963-67. In the Ghilotti case, the court interpreted the "likely to reoffend" standard to mean a substantial danger, but not a better than even chance of new sexual violence. Id. at 954, 967-77. The case was remanded for further proceedings, $i d$. at 954, 977, and Ghilotti remains confined at Atascadero as an SVP, see supra note 348.

377. Kansas v. Hendricks, 521 U.S. 346, 365-66 (1997).

378. See id. at 366-67.

379. Id. at 368 n.4. The Supreme Court noted as significant the fact that Hendricks was placed in the Kansas Department of Health and Social and Rehabilitative Services and was housed in a unit segregated from the general prison population that was operated by trained individuals who were not employees of the Department of Corrections. Id. at 368 .

380. Brief of the Association for the Treatment of Sexual Abusers as Amicus Curiae in Support of Petitioner, Hendricks (No. 95-1649), available at 1996 WL 471027, at*11 (1996) (citing numerous studies); see also Brief of the Menninger Foundation et al. as Amicus Curiae in Support of Petitioner, Hendricks (No. 95-1649), available at 1996 WL 470942, at *26-29 (1996) (discussing the evolution of psychiatric treatment for SVPs and concluding, "modern psychiatry offers a host of beneficial treatments for SVPs"). In his Hendricks dissent, Justice Breyer cited these two amicus briefs for the proposition that SVPs are treatable, and he noted: "Indeed, no one argues to the contrary." Hendricks, 521 U.S. at 378 (Breyer, J., dissenting).

381. Indeed, SVP legislation in some states specifically identifies paraphilia as the mental disorder that may qualify a person an SVP. See, e.g., ARIZ. REV. STAT. AnN. § 36-3701 (West Supp. 2002) (defining mental disorder as "a paraphilia, personality disorder or conduct disorder or any combination of paraphilia, personality disorder and conduct disorder that predisposes a person to commit sexual acts to such a degree as to render the person a danger to the health and safety of others"). 
nonconsenting persons. ${ }^{382}$ SVPs, however, are also often diagnosed as psychopathic, a personality disorder featuring "manipulativeness, pathological lying, shallow affect, and denial of responsibility."383 After all, SVP laws are successor legislation to sexual psychopath laws. ${ }^{384}$ Psychopaths are believed to be untreatable ${ }^{385}$ because their deficits in learning and affect are assumed to be inborn and immutable. ${ }^{386}$ Nevertheless, a recent study funded by the National Institute for Mental Health and the MacArthur Foundation, reveals that violence potential is significantly reduced for psychopathic civil psychiatric patients who are actively involved in therapy, even on an outpatient basis. ${ }^{387}$ Psychopathic patients who received seven or more standard outpatient treatment sessions ${ }^{388}$ during a ten-week period were approximately three times less likely to be violent during a subsequent ten-week period than those who received fewer or no treatment sessions. ${ }^{389}$ "These findings," claimed the researchers, "challenge our conception of psychopathy as an inalterable personality disorder that directly elevates violence risk and eviscerates treatment efforts." 390 Instead of viewing psychopaths as incurable and diverting scarce clinical resources to more treatable patients, this study suggests "that concentrating treatment resources on the high-risk group of patients with psychopathic traits may be maximally efficient in terms of violence reduction." $" 391$ If involuntary

382. Am. Psychiatric Ass'N, Diagnostic and Statistical Manual of Mental DisORDERS (DSM-IV-TR) 566 (4th ed. 2000). In its amicus brief to the Supreme Court in Hendricks, the Association for the Treatment of Sexual Abusers noted that two forms of paraphilia - pedophilia and sexual sadism - are paraphilias that are included within the DSM and are encompassed within the definition of "mental abnormality" in the Kansas SVP Act. Brief of the Association for the Treatment of Sexual Abusers as Amicus Curiae in Support of Petitioner, Hendricks, (No. 95-1649), 1996 WL 471027, at *7. Although rape, which is "widely recognized by experts in the treatment and assessment of sex offenders to constitute a legitimate diagnostic category," is a paraphilia, it is not included within the DSM as a mental disorder and is not encompassed within the definition of "mental abnormality" in the Kansas SVP statute. Id. at *7-8.

383. Jennifer L. Skeem, John Monahan, \& Edward P. Mulvey, Psychopathy, Treatment Involvement, and Subsequent Violence Among Civil Psychiatric Patients, 26 LAW \& Hum. BEHAV. 577, 578 (2002).

384. See supra note 290

385. Indeed, the prevailing notion is that treatment is not merely ineffective for psychopaths, but that such treatment is iatrogenic, that is, the treatment makes psychopaths more likely to recidivate violently. Skeem, Monahan \& Mulvey, supra note 383 , at 577-81, 594 (discussing empirical studies that found treatment of psychopaths to be ineffective or iatrogenic).

386. Id. at 578 .

387. See id. at 594, 598-99.

388. The authors described these sessions as "traditional outpatient mental health services" and "treatment as usual." Id. at 595.

389. Id. at 594.

390. Id.

391. Id. at 598. Only eight percent of psychopathic patients who received seven or 
commitment of specially categorized patients is truly a "civil" commitment, and not simply more punishment for those we fear, then society must be prepared to provide the treatment necessary for them to achieve release without resort to escape.

Indeed, Texas has recently enacted SVP legislation that differs from other states' SVP legislation in one important respect: Upon a determination that the person is an SVP, he is committed for outpatient treatment. ${ }^{392}$ Although the SVP must comply with numerous requirements imposed to ensure his compliance with treatment and supervision and to protect society, ${ }^{393}$ and although the outpatient status continues until he is no longer likely to engage in a predatory act of sexual violence, ${ }^{394}$ Texas SVPs are not subject to inpatient treatment. ${ }^{395}$ Texas's reliance on outpatient treatment of SVPs may prove to be a preferable alternative to indeterminate, and potentially lifetime, inpatient confinement for this population. When we punish SVPs for the despicable crimes they commit, we treat them as responsible adults. If we release them at the end of their penal sentences - even with stringent requirements to assure they undergo treatment and to protect society-we treat them as responsible adults. If they violate those requirements and we punish them for doing so, ${ }^{396}$ again, we treat them as responsible adults. Such consistent treatment of SVPs affirms the moral legitimacy of the criminal law. ${ }^{397}$

more outpatient treatment sessions during the first ten weeks after hospital discharge were violent during the ten subsequent weeks, compared with twenty-four percent of psychopathic patients who received six or fewer outpatient treatment sessions. Id.

392. Tex. Health \& Safety Code AnN. § 841.081 (Vernon Supp. 2003). The law passed the Texas Legislature in 1999 and was signed into law by then Texas Governor, now United States President, George W. Bush. 1999 Tex. Gen. Laws ch. 1188, § 4.01.

393. Tex. Health \& Safety Code AnN. § 841.082 (Vernon Supp. 2003).

394. Id. § 841.081.

395. See Rahn Kennedy Bailey, The Civil Commitment of Sexually Violent Predators: A Unique Texas Approach, 30 J. AM. ACAD. PSyCHIATRY \& L. 525, 525-32 (discussing the exclusive use of outpatient treatment and supervision in Texas as an alternative to inpatient commitment of SVPs).

396. In Texas, an SVP who violates a requirement imposed on him for outpatient commitment engages in a felony. Tex. Health \& SAfETy CODE AnN. § 841.085 (Vernon Supp. 2003).

397. Eric Janus asserted that the Supreme Court's decision in Hendricks, upholding the constitutionality of SVP inpatient civil commitment, places at risk "the moral legitimacy of the criminal law." Eric S. Janus, Hendricks and the Moral Terrain of Police Power Civil Commitment, 4 Psychol. PuB. POL'y \& L. 297, 322 (1998). The line between civil and criminal is obliterated if a state can punish a person as criminally responsible for his actions and then, upon completion of that sentence, civilly commit him as mentally 


\section{Clarifying the Authority to Apprehend Escapees}

In those few cases in which appropriate security measures and enhanced treatment opportunities do not prevent the escape of a special civilly committed patient, authority to apprehend the escapee and to return him to the mental treatment facility should be clearly articulated. For example, a New York statute provides that if an insanity acquittee escapes, the facility staff shall immediately notify the state police, the sheriff of the county where the escape occurred, and any person the facility believes to be in danger. Any peace officer is empowered to apprehend, restrain, transport to, and return the escapee to the facility from which the escape occurred. ${ }^{398}$ In the District of Columbia, a statute requires the court that ordered the insanity acquittee's confinement, upon the government's request, to order the acquittee's return to the hospital from which the escape occurred. That return order is effective throughout the United States. Any judicial officer within whose jurisdiction the escaped person is found is required to apprehend the escapee and deliver him for return to the hospital. ${ }^{399}$ Similarly, other statutes establish peace officer authority to return regular civilly committed mental patient escapees. ${ }^{400}$

Peace officers attempting to apprehend escapees need the assistance of their co-professionals in other law enforcement organizations, and the authority to provide that assistance should be specified. For example, when Ronald Rogers escaped from Atascadero and fled north toward Oregon, California peace officers desired to use the computerized index of identification, criminal identification, crime, and other records in the National Crime Information Center (NCIC), established and maintained

\footnotetext{
abnormal and unable to control his dangerousness. See Stephen J. Morse, Fear of Danger, Flight from Culpability, 4 PSYCHOL. PUB. POL'Y \& L. 250 (1998).

It is utterly paradoxical to claim that a sexually violent predator is sufficiently responsible to deserve the stigma and punishment of criminal incarceration, but that the predator is not sufficiently responsible to be permitted the usual freedom from involuntary civil commitment that even very predictably Id. at 258 . dangerous but responsible agents retain ....

398.

D.C. CODE ANN. § 24-501(i) (2001).

400. See, e.g., CAL. WELF. \& INST. CODE $§ 5358.5$ (West 1998) (providing that a mental health conservator may request a peace officer to detain and return his conservatee to the mental health facility from which the escape occurred); N.Y. MEnTAL HYG. L. § 29.19 (McKinney 2002) (providing that at the request of a representative of a facility from which a civilly committed patient escaped, "any peace officer, acting pursuant to his special duties, or any police officer who is a member of an authorized police department or force or of a sheriff's department" may apprehend, transport, and return the escapee to the facility from which the escape occurred).
} 
by the Federal Bureau of Investigation. ${ }^{401}$ They believed, however, that such information was only available to them if they were seeking to arrest an individual who committed either a state or federal crime. ${ }^{402}$ For this reason, they sought and obtained warrants for Rogers's arrest, charging him with the nonexistent crime of escape and of unlawful flight to avoid prosecution. ${ }^{403}$ Nevertheless, even under current law, access to NCIC information is also available for persons who are missing and who are under a proven mental disability. ${ }^{404}$ Conceivably, Rogers could have been considered a missing person for the purpose of accessing the NCIC database. If this interpretation is incorrect, the law should be amended to assure access to that database by peace officers seeking to apprehend mental patient escapees. Similarly, federal extradition laws should be amended to allow the return of an apprehended mental patient escapee to the state from which the escapee departed. ${ }^{405}$

Assuring needed assistance in the apprehension of mental patient escapees seems preferable to criminalizing patient escapees simply because such assistance is not assured. Criminalizing a patient's escape can have devastating results for the patient. In California, for example, the definition of SVP requires that the person be "convicted of a sexually violent offense against two or more victims." ${ }^{406}$ If SVP escape is criminalized, then an SVP's escape may well constitute a third strike against him, resulting in a twenty-five year to life penal sentence. ${ }^{407}$ Although he completed his sentence for the sex crimes he committed and cannot be further punished for those acts, we were able to civilly commit him to incapacitate him from committing future sex crimes. But if the SVP's escape is criminalized, we will be able to punish him by imprisoning him for life. Are we doing so because he committed another heinous sex crime and deserves punishment for that act? No, he did not commit that crime. We claim we are punishing him because he

401. See 28 U.S.C. $§ 534(2000)$

402. Interview with L.J. Holt, Chief of Police Services, Atascadero State Hospital, in Atascadero, Cal. (Aug. 8, 2002).

403. Id.; see supra notes 4-7 and accompanying text.

404. Federal Bureau of Investigation, United States Department of Justice, National Crime Information Center (NCIC), Federation of American Scientists, at http://www.fas.org/ irp/agency/doj/fbi/is/ncic.htm (last visited Feb. 18, 2003).

405. See supra note 7 (discussing 18 U.S.C. \$1073, which authorizes federal prosecution for the crime of unlawful flight to avoid prosecution or extradition to the state from which the arrestee escaped to face state criminal charges).

406. CAL. Welf. \& InST. CODE § 6600(a)(1) (West Supp. 2003)

407. See CAL. Penal Code $§$ 667(b)-(i) (West 1999); id. § 1170.12 (West Supp. 2003). 
is dangerous and escaped nonpenal confinement for isolation and treatment of that dangerous condition. Does he really deserve lifetime punishment for that act? Or should he be returned, as are other escaping civilly committed patients, to the treatment facility from which he escaped? In reality, we want to punish him simply because he is an SVP, and we believe he has not been punished enough for the sex crimes he previously committed. Perhaps, if we really want to continue punishing SVPs, even though they served their criminal sentences for the sex crimes they committed, we should decrease security and make it easy for them to escape, so we can prosecute them for escape.

\section{Perceiving Patients, Not Prisoners}

In the middle ages, mentally disordered persons were treated as criminals. Mental disorder was thought to have a diabolical source, and the evil spirits had to be exorcized from their victims by flagellation, scourging, burning, and other forms of torture. At that time, confinement for purposes of "treatment" was accomplished by chaining the unfortunate recipients in dungeons and jails along with other criminals. ${ }^{408}$

Today, mental disorder is considered a medical or biological problem - a result of organic or chemical conditions within the person. ${ }^{409}$ Mental patients are treated with psychotropic medication and brief psychotherapeutic intervention. When involuntary treatment is required, patients are typically detained for short periods in community treatment settings.

But not so for "special" civilly committed mental patients whose lives have been tainted by their involvement in the criminal law-twicecursed $^{410}$ as mad and bad. ${ }^{411}$ We hate mentally ill ex-convicts. We

408. U.S. DeP'T OF Health, EdUC. \& WelF., MENTAL ILLNESS AND ITS TREATMENT Past \& PRESENT 5 (1965); S.J. BarRows, The CRIMINAL InSANE IN THE United STATES AND IN FOREIGN COUNTRIES, S. DOC. No. 273, at 5 (1898).

409. See REISNER ET AL., supra note 96, at 5. This model of mental disorder is known as the medical model. Other models of mental disorder exist, including psychoanalytic, behavioral, and social/family systems models. These alternative models focus on psychosocial issues. $I d$.

410. But $c f$. William Shakespeare, The Merchant of Venice, act 4, sc. 1, lines

184-87 (William George Clarke \& William Aldis Wright eds., 1987).

The quality of mercy is not strain'd,

It droppeth as the gentle rain from heaven

Upon the place beneath: It is twice bless' $d$

It blesseth him that gives and him that takes. Id. (emphasis added).

411. Our attitude regarding mentally disordered persons who are or who have been involved in the criminal law is a prime example of sanism. As described by Michael Perlin, "sanism' is an irrational prejudice of the same quality and character of other irrational prejudices that cause (and are reflected in) prevailing social attitudes of racism, 
believe they have not been punished enough for their crimes. We detest mentally incompetent criminal defendants. We believe they are guilty, but their current mental condition precludes us from holding a trial to establish their guilt so that we may impose appropriate punishment. We despise insanity acquittees. We know they have committed criminal acts but their mental condition at the time they acted precludes us from imposing punishment upon them. We are confident that they tricked the jury into finding them not responsible. We believe that SVPs are the very personification of evil. For their sins, they deserve more than mere mortal punishment - they deserve eternal damnation. Treatment, rehabilitation, and release for these monsters? So that they may prey upon new victims? We pray not.

Although we cannot punish these special mental patients, we use the civil commitment process to continue their incarceration. We claim we are doing so to incapacitate them so that they cannot commit dangerous acts. But their confinement is a surrogate for punishment. ${ }^{412}$ If they escape, we want to treat them, not as other civilly committed mental patients, but as criminals.

In 1898, S.J. Barrows observed: "Ask what a State does with its insane prisoners, ask how it protects society on the one hand and fulfills its duty to an irresponsible member on the other, and we may judge of its degree of advancement in civilization by the response." 413 By that measure, we are still in the Middle Ages.

sexism, homophobia, and ethnic bigotry." Michael L. Perlin, "Half-Wracked Prejudice Leaped Forth": Sanism, Pretextuality, and Why and How Mental Disability Law Developed as It Did, 10 J. ConTEMP. Legal Issues 3, 4 (1999); see Michael L. Perlin, On "Sanism", 46 SMU L. REV. 373, 388-406 (1992) (discussing the concept of sanism).

412. An American Psychiatric Association task force studying dangerous sex offenders asserted that sexual predator commitment statutes "reflect a backlash against determinate sentencing reform and are devised to extend the punishment of sex offenders and to protect society.... [D]rafters of sexual predator commitment statutes have attempted to cloak their quasi-punitive intent in the language of medical commitment." AM. PSYCHIATRIC Ass'N, supra note 373, at 172-73. The task force urged psychiatry to "vigorously oppose these statutes in order to preserve the moral authority of the profession and to ensure continuing societal confidence in the medical model of civil commitment." Id. at 173.

413. BARROWS, supra note 408 , at 8 . 
